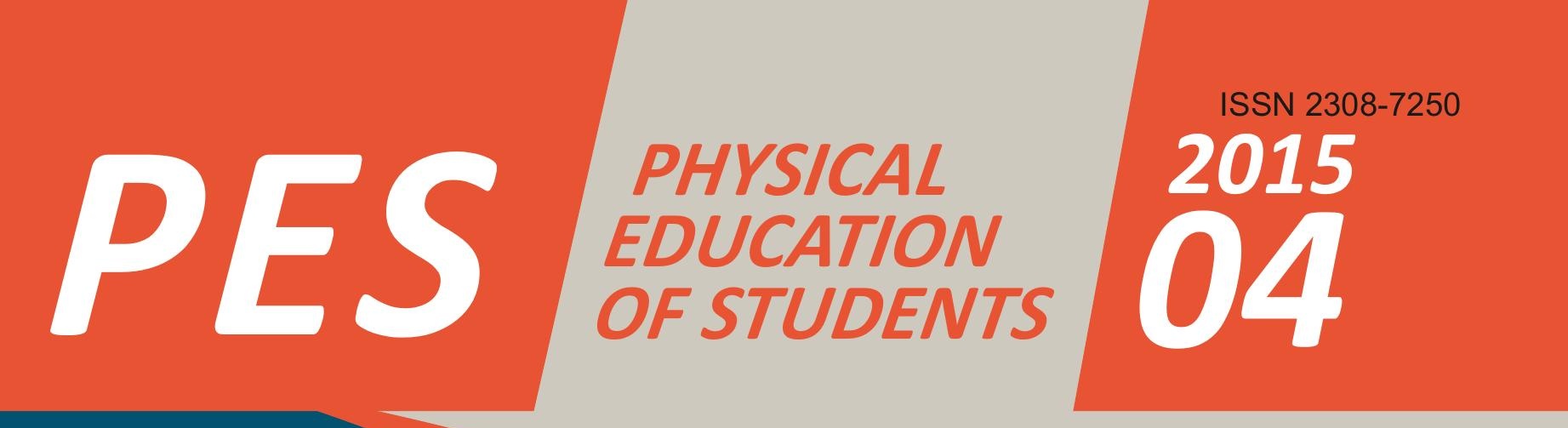


Key title: Fiziceskoe vospitanie studentov

Abbreviated key title: Fiz. vosp. stud.

ISSN 2075-5279 (Russian ed. Print), ISSN 2223-2125

(Russian ed. On line),

Key title: Physical education of students

Abbreviated key title: Phys. educ. stud.

ISSN 2308-7250 (English ed. Online)

Founders: Kharkov National Pedagogical University

Editor-in-chief:

lermakov S.S., Kharkov, Ukraine.

Scientific consultant:

Zaporozhanov V.A., Olsztyn, Poland

Editorial college:

Abdelkrim Bensbaa, Abu Dhabi, UAE.

Antala Branislav, Bratislava, Slovakia.

Boraczynski Tomasz, Olsztyn, Poland.

Boychenko S.D., Minsk, Byelorussia.

Boychuk U.D., Kharkov, Ukraine.

Cieślicka Mirosława, Bydgoszcz, Poland.

Corona Felice, Salerno, Italy.

Dmitriev S.V., Lower Novgorod, Russia.

Fathloun Mourad, Kef, Tunisia.

Görner Karol, Banska Bystrica, Slovakia.

Giovanis Vassilios, Athens, Greece.

Jagello Wladislaw, Gdans'k, Poland.

Jorge Alberto Ramirez Torrealba, Maracay, Venezuela.

Khudolii O.M., Kharkov, Ukraine.

Ionova O.M., Dornach, Switzerland.

Kozina Z.L., Radom, Poland.

Kondakov V.L., Belgorod, Russia.

Korobeynikov G.V., Kiev, Ukraine.

Leikin M.G., Portland, USA.

Malinauskas Romualdas, Kaunas, Lithuania.

Maciejewska-Karlowska Agnieszka, Szczecin, Poland.

Nosko N.A., Chernigov, Ukraine.

Prusik Katarzyna, Gdans'k, Poland.

Prusik Krzysztof, Gdans'k, Poland.

Sawczuk Marek, Szczecin, Poland.

Sobyanin F.I., Belgorod, Russia.

Tkachuk V.G., Kiev, Ukraine.

Yan Wan Jun, Shijiazhuang, China.
A journal is ratified the MES of Ukraine: physical education and sport, pedagogical sciences (№1528, 29.12.2014; №1279, 06.11.2014).

Journal is reflected in databases:

1) DOAJ (Directory of Open Access Journals)

http://www.doaj.org

CABI (CAB Direct) http://www.cabdirect.org

WorldCat http://www.worldcat.org

SHERPA/RoMEO http://www.sherpa.ac.uk

Open Science Directory (EBSCO information services) -

http://www.opensciencedirectory.net

PBN (Polish Scholarly Bibliography)

https://pbn.nauka.gov.pl/journals/42127

ERIH PLUS (The European Reference Index for the

Humanities and the Social Sciences)

- https://dbh.nsd.uib.no

IndexCopernicus

http://journals.indexcopernicus.com

Russian science citation index

http://elibrary.ru

2) BASE (Bielefeld Academic Search Engine)

http://www.base-search.net

Scilit - http://www.scilit.net

Academic Journals Database

http://journaldatabase.org

CORE http://core.kmi.open.ac.uk

ROAD - http://road.issn.org

DIIRJ (Directory Indexing of International Research

Journals) http://drji.org/

Google Scholar http://scholar.google.com.ua

OAJI (Open Academic Journals Index)

http://oaji.net/journal-detail.html?number=770

WorldWideScience Alliance http://worldwidescience.org

Ulrich's Periodicals Directory

http://ulrichsweb.serialssolutions.com/login

V.I.Vernadskiy National Library of Ukraine

http://www.nbuv.gov.ua

Library of the Russian state university of physical

culture, sport and tourism

http://lib.sportedu.ru/Press/FVS

Certificate to registration:

KB 20682-10482PR от 31.03.2014.

Frequency - 6 numbers in a year.

Address of editorial office:

P.O.Box 11135, Kharkov-68, 61068, Ukraine

Tel. +380994306922

http://www.sportedu.org.ua

e-mail: sportart@gmail.com

Address of editorial office (Poland):

Sport str. 2, of.209, 85-064 Bydgoszcz, Poland

Editor-in-Chief: Sergii lermakov, tel.: +48886680976

Deputy Editor: Mirosława Cieślicka, tel.: +48600945007

e-mail:cudaki@op.pl 


\section{CONTENTS}

Gordienko Y.V. Theoretical training in physical education of higher educational establishments' girl students .3

Dudko M.V. Characteristic of bio-geometric profile of students' posture and physical fitness in process of physical education. 10

Martsiv V.P. Model characteristics of average skill boxers' competition functioning 17

Masliak I.P. Quickness and endurance fitness of pedagogic college girl students under influence of cheer-leading

Pyatnickaya D.V. Development of girl-students' physical qualities at extracurricular cheer-dance classes (cheer-dance show)

Rovniy A.S., Lastochkin V.M. Mechanisms of adaptation to intensive loads of 400 meters' hurdles runners at stage of initial basic training

Yurchyshyn Y.V. Modern information tools: their place in students' extra-curriculum and involvement of them in motor activity of health related orientation

Jagiello Wladyslaw, Kozina Zh.L., Jagiello Marina. Somatic aspects of sports championship in taekwon-do ITF

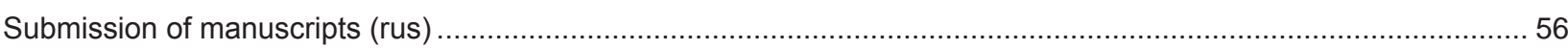

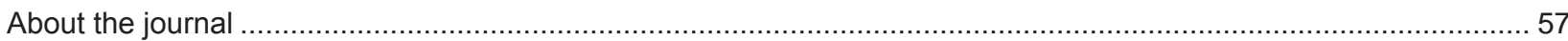

Contents

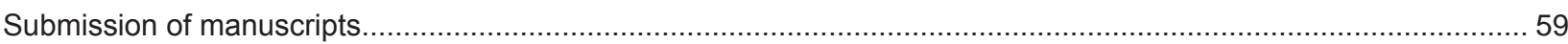




\title{
THEORETICAL TRAINING IN PHYSICAL EDUCATION OF HIGHER EDUCATIONAL ESTABLISHMENTS' GIRL STUDENTS
}

Gordienko Y.V.

Poltava National Technical Yuri Kondratyuk University

\begin{abstract}
Purpose: testing and analysis of theoretical-methodic training of girl students at physical education classes. Material: in the research $452^{\text {nd }}$ year girl students of 18-19 age, participated. One group dealt with power-lifting and volleyball. Second group - practiced trainings by usual academic program. Results: it was found that girl students' theoretical knowledge corresponds to middle level. It was also established that increase of motivation for acquiring and mastering knowledge facilitates effectiveness of physical education trainings' construction. Conclusions: absence of physical education theoretical knowledge or its low level in girl students sharply reduces effectiveness of training and education, weakens interest to physical exercises' and sports' practicing.
\end{abstract}

Key words: girl students, physical education, power-lifting, test, control.

\section{Introduction}

Physical culture in HEE is an academic discipline and important basic component of formation of youth's general culture. It is known that mastering only practical skills of physical perfection, without sufficient theoretical and methodic knowledge does not permit for students to correctly apply their skills in independent practicing of physical exercises $[2-5 ; 9 ; 26 ; 32,34-36 ; 40]$ и во время профессиональной деятельности [3; 8; $11 ; 15 ; 16 ; 20-26]$.

Studying this problem, scientists T. Krutsevich, O. Marchenko and A. Tomenko conclude that important place in perfection of physical education system belongs to formation of values through theoretical training and increase of pedagogic control's effectiveness [10; 19]. In works by V. Sorokina and V. Temchenko main components of students' personal education level have been found. With it the authors underline need in control of theoretical knowledge in physical education. The authors affirm that presence of objective information permits to find strong and weak sides of structure of preparedness, to realize proper planning and correction of training process $[15 ; 16]$.

Increase of effectiveness of pedagogic control over students' fitness level is rather important in perfection of physical education [6;22-25, 37, 38]. N. Moskalenko et al. substantiated innovative technologies of physical education. They are directed on strengthening of students' health with the help of theoretical training and cultivation of personal values and motives for trainings [12]. In researches by N. Zavidovskaya and P. Oksem it is noted that theoretical aspects of education in sphere of physical culture have declarative character in higher school and exist only on pages of program documents [7; 14].

Analysis of publications shows that in conditions of higher education's reforming problem of theoretical learning and control over students' progress in practical and theoretical skills and knowledge acquires special urgency and requires further researches.

Purpose, tasks of the work, material and methods

The purpose of the research is testing and analysis of theoretical-methodic training of girl students at physical education classes. The methods of the research: in the course of our work we used pedagogic observation for analysis and assessment of girl students' theoretical knowledge. Experimental researches were conducted on the base of Poltava National Technical Yuri Kondratyuk University (PoltNTU). In the research $452^{\text {nd }}$ year girl students of 18-19 age, participated. First group dealt with power-lifting and volleyball. Second group - practiced trainings by usual academic program.

\section{Results of the researches}

As the main hypothesis of this research we assumed that theoretical knowledge indirectly facilitates significant increasing of purposefulness and effectiveness of physical education process. Proper organization of physical education trainings in university shall envisage compulsory lecture hours for theoretical course. In this

(c) Gordienko Y.V.2015

http://dx.doi.org/10.15561/20755279.2015.0401 
case all material to be studied is distributed by semesters. Topics of lecture course shall contain main information about theory and methodic of physical education and sports, healthy life style, professional-applied physical fitness.

In PoltNTU rather interesting teaching modules on program "Physical education" are practiced. Alongside with practical part (trainings and practical-methodic classes) theoretical section is stipulated. This section forms students' world vision, scientific-methodic knowledge and facilitates formation of positive attitude to physical culture and sports. Every module envisages complex of compulsory lessons. It includes also theoretical and independent students' trainings. Theoretical course is delivered in the form of lectures (12 academic hours). The course offers independent studying of the subject with the help of recommended literature and Internet resources. Student's individual work implies profound studying of separate theoretical and methodic questions of physical fitness's perfection, health improvement, sport's perfection.

Lecture course includes the following topics:

Lecture № 1. Physical culture and sports as natural component of general culture of society. Physical culture (PC) as social phenomenon in life of society. Main means of PC. PC and sports in life of modern man. Factors, determining demand of modern man in practicing of physical exercises. PC and sports in system of higher school. Functioning of sport club (SC).

Lecture № 2. Natural-scientific principles of physical education. Human organism as uniform complex biological system. Motor functioning and its influence on functioning of human organs and organism. Physical inactivity and hypokinesia. Laws of human organs' and organism systems' development in process of physical; exercises' practicing. Physiological characteristic of motor functioning means.

Lecture № 3. Principles of healthy life style (HLS). Conception of health. Main components of HLS and their characteristics. Factors, influencing on quality of life and life span of an individual. Motor functioning as important component of healthy life style.

Lecture № 4. Principles of physical and sports training. The essence of training process. Methodic principles of training's and its components' construction. Sport competitions as mean and method of sportsmen's training. Specific features of organization and planning of sport trainings.

Lecture 5. Professional-applied physical trainings (PAPT). Content and main tasks of PAPT. Factors, determining importance and general orientation of PAPT. Formation of applied movements, motor skills. Cultivation of special physical qualities. Dynamic of human workability during day, week. Means of workability's rising; struggle with industrial fatigue; prevention of professional diseases. Tests and control normative of PAPT. .

Lecture № 6. Physical culture in scientific organization of work (SOW). Physical culture and sports in SOW. Purpose and main tasks of physical culture in SOW. Formation of system of knowledge, motor skills in purposeful application of physical culture and sports' means in work and leisure for prevention of industrial fatigue. Prophylaxis of professional diseases; rising of productivity; preservation and strengthening of health.

Independent classes are organized with the help of electronic library of the university. Students deepen their knowledge with manuals and methodic recommendations, Internet resources. For control of theoretical knowledge we conducted pedagogic experiment in the form of theoretical testing at the end of $2^{\text {nd }}$ academic year.

For determination of students' theoretical knowledge questionnaire is used at department of physical education of PoltNTU. The questionnaire contains 50 questions. Every question has four alternative answers, from which one, correct, shall be chosen. The tests include questions about healthy life style, history of physical education and sports, specific features of physical exercises' practicing, planning of physical loads in independent trainings.

Criteria of students' knowledge assessment depend on quantity of correct answers. Every correct answer brings 1 point: 50-40 points - "excellent"; 39-30 points - "good"; 29-20 points -satisfactory"; 19 points and less - "unsatisfactory".

For experiment we formed three groups of girl students. Two experimental groups: EG1 (girl students practiced power-lifting by the author's methodic); EG2 (girl students trained volleyball). One control group CG consisted of girl students, who were trained as per traditional academic program of PoltNTU. Quantity of girl students in every group was 15 persons. By mean group indicators of physical condition and physical fitness all 
girl students did not confidently differ. We carried out experimental substantiation of training process's methodic. Effectiveness of the offered methodic was assessed by results of girl students' performances at competitions and by control over their emotional and physiological status.

Analysis of testing of girl students' theoretical knowledge in all directions of physical trainings showed that it corresponds to middle level. More detail results of the researches showed low level of theoretical knowledge of girl students, who were trained by traditional physical education program (CG) (see table 1). Girl students from volleyball group (EG2) had higher level of knowledge. The highest indicators belonged to girl students - power lifters (EG1).

Table 1

Assessment of knowledge in "Physical education" subject of PoltNTU second year girl students
\begin{tabular}{|l|l|c|c|c|c|c|c|}
\hline \multirow{2}{*}{ No } & \multirow{2}{*}{ Mark } & \multicolumn{2}{|c|}{ EG1 } & \multicolumn{2}{c|}{ EG2 } & \multicolumn{2}{c|}{ CG } \\
\cline { 3 - 8 } & & quantity & $\%$ & quantity & $\%$ & quantity & $\%$ \\
\hline 1 & Excellent & 8 & 40 & 6 & 30 & 4 & 20 \\
\hline 2 & Good & 7 & 35 & 6 & 30 & 2 & 10 \\
\hline 3 & Satisfactory & 5 & 25 & 6 & 30 & 12 & 60 \\
\hline 4 & Unsatisfactory & & & 2 & 10 & 2 & 10 \\
\hline
\end{tabular}

Comparing of inter group indicators showed that the highest level of theoretical preparedness is observed in EG1. In this group mean indicator was $35.85 \%$ of correct answers. These results are significantly higher than in CG. In Eg1 this result was $33.65 \%$. In CG we registered only $28.85 \%$ of correct answers. Nearly all indicators of "Power-lifting" and "Volleyball" girl students' theoretical preparedness correspond to middle and high levels.

Testing results permit to affirm that EG1 girl students mastered theoretical knowledge in physical education better than EG2 and CG girl students. The best results of testing were demonstrated by "Power-lifting" girl students. It witnesses about higher scope of knowledge and higher quality of these girl students' thinking.

Also we can affirm that EG1 girl students paid more attention to independent work with subject. In their independent classes the girl students see possibility to achieve certain aim of learning cognitive activity in training process. In EG2 group we did not observe interest to subject "Physical education". This group's girl students received theoretical knowledge only from academic material oriented on curriculum. The presented results of the researches witness about insufficient "Physical education" theoretical knowledge of CG girl students.

Absence or low level of girl students' theoretical knowledge in physical education sharply reduce effectiveness of training, weaken interest to physical exercises' practicing; hinder cultivation of students' positive attitude to systemic independent physical culture trainings.

\section{Discussion}

Results of the conducted experiments are confirmed by other researches [29-31, 33-40]. The authors affirm that scope of knowledge about physical culture is in direct proportion to level of motor functioning's mental component. It results in better progress in mastering of skills when practicing physical exercises.

Also we confirmed the data about unsatisfactory level of girl students' theoretical-methodic preparedness in physical education (S. Berezka [2]; N. Moskalenko, T. Sycheva [12]). Results of the researches permitted to supplement the data about effectiveness of physical education trainings' construction by choice of students that facilitate increase of motivation for acquiring and mastering of knowledge (G.V. Vlasov [4], V.A. Temchenko [18]). We supplemented also information that increasing of physical fitness is accompanied by rising of students' theoretical knowledge level (T. I. Dukh[6]). 
The data about positive influence of power lifting program on girl students' interest in theoretical course of physical education and improvement of their knowledge of this subject are the novelty of the researches.

\section{Conclusions:}

Results of the researches permit to affirm that author's model of formation of modern HEE girl students' harmonious personalities under influence of power-lifting trainings can be considered in working out of new conception of governmental physical education program. With it, for increasing of cognitive activity and girl students' interest in self education it is necessary to perfect teaching of theoretical section, involving new informational technologies, effective and modern teaching methods.

\section{Acknowledgement}

The research has been fulfilled in compliance with plan of scientific research works of Ministry of education and science, youth and sports of Ukraine by topic 3.6 "Scientific-theoretical principles of innovative technologies in physical education of different population strata" (state registration number 0111U001169).

\section{Conflict of interests}

The author declares that there is no conflict of interests.

\section{References:}

1. Afanas'iev VV, Gavrilova NM, Mikhajlenko VM. Fizichne vikhovannia u zhitti studentok [Physical education in girl students' life]. Pedagogics, psychology, medical-biological problems of physical training and sports. 2008; 10: 13-16. (in Ukrainian)

2. Berezka SM. Teoretichni ta metodichni znannia studentiv z navchal'noi disciplini «fizichne vikhovannia» [Theoretical and methodic knowledge of students in discipline "physical education"]. Pedagogics, psychology, medical-biological problems of physical training and sports. 2011; 3: 12-14. (in Ukrainian)

3. Bilogur VIe. Teoretiko-metodichne zabezpechennia fizichnogo vikhovannia u vishchikh zakladakh osviti. Cand. Diss. [Theoretical-methodic provisioning of physical education in higher educational establishments. Cand Diss.], Rivne, 2002. (in Ukrainian)

4. Vlasov GV. Vivchennia dinamiki sportivnikh upodoban' studentiv vishchikh medichnikh navchal'nikh zakladiv [Study of sport bents' dynamic of students of higher medical establishments]. Naukovij visnik Donbasu. 2011;1(13):45-50. (in Ukrainian)

5. Volkov V. Problema rozrobki tekhnologii upravlinnia fizichnoiu pidgotovkoiu suchasnoi students'koi molodi [Problem of working out of technology of modern students' physical trainings' control]. Teoriia $i$ metodika fizichnogo vikhovannia i sportu, 2008;2:41-46. (in Ukrainian)

6. Dukh TI. Teoretiko-metodichna ta fizichna pidgotovka studentiv iz zastosuvanniam vzaiemonavchannia u processi fizichnogo vikhovannia. Cand. Diss. [Theoretical-methodic and physical training of students with application of peer learning in physical education. Cand. Diss.], Lviv, 2014. (in Ukrainian)

7. Zavidivs'ka NN. Pedagogichni zasadi formuvannia zdorovogo sposobu zhittia studentiv vishchikh zakladiv osviti ekonomichnogo profiliu. Cand. Diss. [Pedagogic principles of formation of higher economic educational establishments students' healthy life style. Cand. Diss.], Lviv, 2001. (in Ukrainian)

8. Klimakova TA. Analiz stanu fizichnogo vikhovannia u vishchikh navchal'nikh zakladakh [Analysis of physical education status at higher educational establishments]. Pedagogics, psychology, medical-biological problems of physical training and sports. 2011; 8: 36-39. (in Ukrainian)

9. Koval'chuk V. Suchasni pidkhodi do ociniuvannia navchal'nikh dosiagnen' iz fizichnogo vikhovannia studentiv [Modern approaches top assessment of educational progress in students' physical education]. Fizichne vikhovannia, sport i kul'tura zdorov'ia u suchasnomu suspil'stvi. 2012;4:285-289. (in Ukrainian)

10. Marchenko O.Iu, Krucevich T.Iu. Vliianie vneshnikh i vnutrennikh faktorov na formirovanie cennostnykh orientacij fizicheskoj kul'tury studentov [Influence of external and internal factors on formation of value orientation of students' physical culture]. XII Mezhdunarodnyj nauchnyj kongress "Sovremennyj olimpijskij i paralimpijskij sport i sport dlia vsekh" [XII International scientific congress "Modern Olympic and paraOlympic sports and sports for all'], Kiev, 2008; T.1:89-90. (in Russian) 
11. Merkulova ZIa. Poshuk diievikh shliakhiv formuvannia rukhovoi kul'turi u procesi fizichnogo vikhovannia studentiv vishchikh tekhnichnikh navchal'nikh zakladiv [Searching of practical ways of motor culture formation in physical education of technical higher educational establishments' students]. Pedagogics, psychology, medical-biological problems of physical training and sports. 2008;6:54-56. (in Ukrainian)

12. Moskalenko N, Sichova T, Anastas'ieva Z. Innovacijni tekhnologii fizichnogo vikhovannia spriamovani na zmicnennia zdorov'ia studentiv [Innovative technologies of physical education, oriented on strengthening of students' health]. Sportivnij visnik Pridnistrov'ia, 2012;2:10-12. (in Ukrainian)

13. Muntian VS. Fight-fitness v programme fizicheskogo vospitaniia studentov vysshikh uchebnykh zavedenij [Fight - fitness in program of higher educational establishments' students]. Physical education of students, 2011;1:94-98. (in Russian)

14. Oks'om P, Berezhna L, Shmatkova A. Stavlennia studentok vishchogo pedagogichnogo navchal'nogo zakladu do fizichnogo vikhovannia [Attitude of higher educational establishments' girl students to physical education]. Teoriia i metodika fizicheskogo vospitaniia, 2008;2:11-14. (in Ukrainian)

15. Okhrimenko OV, Vereshchagina OP. Zavdannia vikladacha - vikhovannia moral'nikh iakostej u students'koi molodi na zaniattiakh z fizichnoi kul'turi i sportu [The task of teacher - cultivation of moral values in students at physical culture and sport trainings]. Pedagogics, psychology, medical-biological problems of physical training and sports. 2008;11:130-133. (in Ukrainian)

16. Prisiazhniuk S. Kriterii ociniuvannia uspishnosti studentiv z predmeta „Fizichne vikhovannia” [Criteria of students' progress assessment in discipline "Physical education"]. Fizichne vikhovannia v shkoli, 2003; 2: 35-38. (in Ukrainian)

17. Sorokina VM, Sorokin DIu. Formirovanie otnoshenij k zdorovomu obrazu zhizni kak professional'noj cennosti u studentov [Formation of attitude to healthy life style as students' professional value]. Sovremennye problemy nauki i obrazovaniia, 2009; 6: 52-56. (in Russian)

18. Temchenko VA. Sportivno orientirovannoe fizicheskoe vospitanie v vysshikh uchebnykh zavedeniiakh $s$ primneniem informacionnykh tekhnologij. Cand. Diss. [Sport oriented physical education in higher educational establishments with application of information technologies. Cand. Diss.], Kharkov, 2015. (in Russian)

19. Tomenko O, Krucevich T. Konceptual'na model' nespecial'noi fizkul'turnoi osviti uchnivs'koi molodi [Conceptual model of students' and pupils' not special physical education]. Sportivnij visnik Pridniprov'ia, 2011;2:164-167. (in Ukrainian)

20. Alekseev N, Kutergin N, Kulinichev A, Gorbatenko A. Integrated method development of general and special students stamina involved in the fight. Physical Education of Students. 2014;3:3-8.

21. Bichescu A. Leisure Time Sport Activities of the Students at Resita University. Procedia - Social and Behavioral Sciences. 2014;117:735-40.

22. Brown GTL. Self-regulation of assessment beliefs and attitudes: a review of the Students' Conceptions of Assessment inventory. Educational Psychology. 2011;31(6):731-48.

23. Buckworth J, Nigg C. Physical Activity, Exercise, and Sedentary Behavior in College Students. Journal of American College Health. 2004;53(1):28-34.

24. DiGironimo N. What is Technology? Investigating Student Conceptions about the Nature of Technology. International Journal of Science Education. 2010;33(10):1337-52.

25. Dudnyk IO. Formation of positive motivation as the basis of students will qualities' perfection in physical culture practicing. Physical Education of http://dx.doi.org/10.15561/20755279.2015.0301

26. Ennis CD. Implementing meaningful, educative curricula and assessments in complex school environments. Sport Educ Soc, 2012;18:115-120.

27. Fomenko E. Practical recommendations for the implementation of health technologies to enhance physical fitness of students in extracurricular classes during non-traditional gymnastics. Pedagogics, psychology, medical-biological problems of physical training and sports. 2014;7:31-6. 
28. Iermakova TS. Peculiarities of forming health culture of pupils in Poland: historical aspect. Pedagogics, psychology, medical-biological problems of physical training and sports. 2014;.6:16-20. http://dx.doi.org/10.6084/m9.figshare.1004090

29. Kozina ZL, Iermakov SS. Analysis of students' nervous system's typological properties, in aspect of response to extreme situation, with the help of multi-dimensional analysis. Physical Education of Students, 2015;3:10-19. http://dx.doi.org/10.15561/20755279.2015.0302

30. Lobko VS. Psycho-physiological characteristics of students-powerlifters of different training experience, who have affections of muscular skeletal apparatus. Pedagogics, psychology, medical-biological problems of physical training and sports. 2015;5:22-26. http://dx.doi.org/10.15561/18189172.2015.0504

31. Martyniuk OV, Vilyanskiy VN. Assessment of students' health condition by indicators of adaptation potential, biological age and bio-energetic reserves of organism. Physical education of students, 2015;3:2028. http://dx.doi.org/10.15561/20755279.2015.0303

32. O'Leary N, Wattison N, Edwards T, Bryan K. Closing the theory-practice gap Physical education students' use of jigsaw learning in a secondary school. European Physical Education Review, 2015; 21: 176-194.

33. Olkhovy OM, Petrenko YM, Temchenko VA, Timchenko AN. Model of students' sport-oriented physical education with application of information technologies. Physical Education of Students, 2015;3:29-37. http://dx.doi.org/10.15561/20755279.2015.0304

34. Pichurin VV. Psychological and psycho-physical training as a factor of personal anxiety at students. Pedagogics, psychology, medical-biological problems of physical training and sports. 2015;3:46-51. http://dx.doi.org/10.15561/18189172.2015.0307

35. Serorez T, Navka P. Methodical features dispensing exercise, used in extracurricular activities to improve health students. Pedagogics, psychology, medical-biological problems of physical training and sports. 2014;5:60-66.

36. Serorez T. The indicators of the physical health of students on the characteristics of the physical fitness, aerobic and anaerobic productivity of their body. Pedagogics, psychology, medical-biological problems of physical training and sports. 2014;9:54-59.

37. Standal ØF, Moen KM, Moe VF. Theory and practice in the context of practicum: The perspectives of Norwegian physical education student teachers. European Physical Education Review, 2014; 20: 165-178.

38. Ward P. The role of content knowledge in conceptions of teaching effectiveness in physical education. Res Q Exerc Sport, 2013; 84: 431-440.

39. Yermakova TS. Individualization of forming health culture in schoolchildren of Polish schools. Pedagogics, psychology, medical-biological problems of physical training and sports. 2015;1:29-33. http://dx.doi.org/10.15561/18189172.2015.0106

40. Zepke N, Butler P, Leach L. Institutional research and improving the quality of student engagement. Quality in Higher Education. 2012;18(3):329-47. 
Information about the author:

Gordienko Y.V.; http:// orcid.org/0000-0002-7762-8176; juligord@i.ua; Poltava National Technical Yuri Kondratyuk University ; Pervomajskij prospect, 24, Poltava, 36011, Ukraine.

Cite this article as: Gordienko Y.V. Theoretical training in physical education of higher educational establishments' girl students. Physical education of students, 2015;4:3-9. http://dx. doi. org/10. 15561/20755279. 2015. 0401

The electronic version of this article is the complete one and can be found online at: http://www. sportpedu. org. ua/html/arhive-e. html

This is an Open Access article distributed under the terms of the Creative Commons Attribution License, which permits unrestricted use, distribution, and reproduction in any medium, provided the original work is properly cited

(http://creativecommons. org/1icenses/by/3. 0/deed. en).

Received: 27.07.2015

Accepted: 16.08.2015; Published: 30.08.2015 


\title{
CHARACTERISTIC OF BIO-GEOMETRIC PROFILE OF STUDENTS' POSTURE AND PHYSICAL FITNESS IN PROCESS OF PHYSICAL EDUCATION
}

Dudko M.V.

Kyiv National Economic University named after Vadym Hetman

\begin{abstract}
Purpose: to determine specific features of bio-geometric profile of posture and physical fitness of students in process of physical education. Material: 250 students were tested. Video-recording and analysis of bio-geometric profile of human posture were fulfilled. Program Torso was used for this purpose. Results: it was found out that only $15.2 \%$ of students had correct posture. The most quantity of posture abnormalities was detected in $36.4 \%$ of the tested. In sagittal plane we observed the following types of abnormalities: round back - in $24.4 \%$ of students, slouching back in $24 \%$ of students. We found that $63.3 \%$ of students with normal posture are in zone of risk. Low backbone flexibility, mobility of hip joints and elasticity of hamstrings was detected on students. Conclusions: students with unsatisfactory bio-geometric profile of posture (scoliosis posture - 43.33\%; round back - 23. 33\%; slouching back - 22. $73 \%$ ) are in the called pre-morbid state of muscular-skeletal apparatus.
\end{abstract}

Key words: students, physical education, posture, visual screening.

\section{Introduction}

In modern conditions, educational process in higher educational establishments is connected with continuously increasing informational flow and with significant psychological loads. It sets high requirements to students' health condition and physical fitness that is important condition of ensuring of students' harmonious development. [13, 20, $23]$.

Most of specialists $[1,3,7,8]$ connect it with unfavorable social economic conditions of life and ecology, with substantial reduction of students' interest to physical culture and sports, weakening of physical education system in higher educational establishments.

Numerous researches $[2,4,10,17-19,22]$ witness that mass character of posture abnormalities - is one of the most pressing problems of modern society. Functional abnormalities of posture are one of the most wide-spread deviations in muscular skeletal system of modern students [8, 9, 24]. Postures disorders negatively influence on function of internal organs, cardio-vascular, respiratory and digestive systems. They negatively impact on human mental; and physical workability [1, 3, 8, 9, 25-30].

At present time there is great number of scientific publications $[4,5,6,7,13,21]$ on studying of posture abnormalities of students and approaches to their correction by physical education means. However, some problems have still been remaining unsolved.

In our opinion, for effective planning of health related work it is purposeful to use "screening" [10]. Its purpose is to detect students with "risk zones" of posture's bio-geometric abnormalities as well as determination of pre-morbid states of muscular-skeletal apparatus (MSA).

Generalizing specialists' views we can state the fact that correction of posture's bio-geometrical profile abnormalities of students is reflected in many publications. At the same time some questions, concerning prophylaxis of such abnormalities have not been profoundly worked out yet.

Purpose, tasks of the work, material and methods

The purpose of the work is to determine specific features of bio-geometric profile of posture and physical fitness of students in process of physical education.

The tasks of he work:

1. To generalize scientific data on prophylaxis and correction of students postures' abnormalities by means of physical education, by data of special literature.

2. To determine the most frequent abnormalities of posture's bio-geometrical profile, level of its state and specificities of students' physical fitness.

The methods of the research: we used the following methods: theoretical analysis and generalization of special scientific-methodic literature, pedagogic observations, pedagogic testing, anthropometry, video recording and analysis

(C) Dudko M.V., 2015

http://dx.doi.org/10.15561/20755279.2015.0402 
of human posture's bio-geometrical profile with the help of program "Torso", visual screening", methods of mathematical statistic. In the research 250 first year students of Kyiv National Economic University named after Vadym Hetman participated.

\section{Results of the research}

Collection of data from students' medical records was conducted with direct participation of vertebraneurology specialist. Visual screening and application of "Torso" program [9] permitted to detect that only $15.2 \%$ of students have normal posture. Types of posture's abnormalities were distributed in the following way: scoliosis posture $36.4 \%$ of the tested, slouching back $24 \%$, round back $-24.4 \%$ of students.

To receive urgent information about bio-geometrical profile of students' postures it is necessary to have simple informative indicators. These indicators shall be easily accessible to physical culture teacher; not require diagnostic apparatuses and great time losses. In our case we used improved record of control over posture's bio-geometric profile [7].

For assessment of posture's bio-geometric profile we used the following indicators:

- In respect to sagittal plane - position of head and torso in respect to vertical axis, chest kyphosis and lumbar lordosis, shape of abdomen, angle between hip and shin;

- In respect to frontal plane - position of head in respect to horizontal axis, location of shoulders, of blades lower angles and pelvis bones, triangles of waist, position of feet.

Every indicator was assessed by three points' scale. We used method of comparison of individual posture on photograph and graphic pictures of variants on sample. "Point" 1 corresponded to mark "bad", "2" - "satisfactory, "3" "good".

All 250 students were tested by map of visual screening of posture's bio-geometrical profile. It permitted to distribute students by levels, separately for every kind of posture: "low", "middle", "high" (see table 1).

Table 1

Distribution of students by state of posture's bio-geometrical profile, \%

\begin{tabular}{|c|c|c|c|}
\hline \multirow{2}{*}{ Type of posture } & \multicolumn{3}{|c|}{ Level of bio geometrical profile state } \\
\cline { 2 - 4 } & low & middle & high \\
\hline Normal posture & 0 & 63.33 & 36.67 \\
\hline Scoliosis posture & 43.33 & 56.33 & 0 \\
\hline Round back & 23.33 & 76.67 & 0 \\
\hline Slouching back & 22.73 & 77.27 & 0 \\
\hline
\end{tabular}

For determination of "risk zones" of functional disorders in muscular skeletal apparatus (MSA) orthopedist assessed students' posture in frontal and sagittal planes. We used map of express control of posture's bio-geometrical profile (norm -2 points, pathologies -1 point). All students were divided into two groups: with normal posture and with posture abnormalities. For determination of "risk zones" of MSA functional disorders we constructed graphs of normal distribution of generalized summarized points of students with normal postures and students with posture abnormalities. Sections of graphs overlapping were classified as "risk zones" (see table 2). 
Determination of level of bio-geometrical profile's state and "risk zones" by integral mark of 17-18 years' age students, points

\begin{tabular}{|c|c|c|c|c|}
\hline Age, years & \multicolumn{3}{|c|}{ Level } & \multirow{2}{*}{ Risk zone } \\
\hline & Low & Middle & High & \\
\hline 17 & $11-17$ & $18-23$ & $24-33$ & $18-20$ \\
\hline 18 & $11-16$ & $17-23$ & $24-33$ & $17-20$ \\
\hline
\end{tabular}

Analyzing the received data we can conclude that $63.33 \%$ of students with normal posture are in "risk zone". It means that these tested require deepened control of bio-geometric profile of posture. They need in prevention prophylaxis of MSA disorders.

Students with different kinds of posture abnormalities and low bio-geometrical profile level are in the so-called pre-morbid state of MSA. Pre-morbid state (from Latin prae - pre and morbus disease) is an initial human state before disease. This state is characterized by reduction of organism's adaptation potential. It has 2 stages of progressing: with prevailing of non-specific changes and preservation of homeostatic characteristics; with prevailing of specific changes in organs and systems (pathology is still not expressed and changes are of compensatory character).

Thus, slouching and round back - are types of posture, which are favorable ground for progressing of pathological kyphosis, while scoliosis posture can result in scoliosis.

At the next stage of our researches we studied physical fitness of students with different types of posture (see table 3).

It was found that students with normal posture have middle level of general endurance $2567.11 \mathrm{~m}(\mathrm{~S}=317.99 \mathrm{~m})$. It should also be noted that students with scoliosis posture and slouching back also have middle level of general endurance- $2467.58 \mathrm{~m}(\mathrm{~S}=357.18 \mathrm{~m})$ and $2440.83 \mathrm{~m}(\mathrm{~S}=283.51 \mathrm{~m})$. But these indicators have statistically significant distinctions $(\mathrm{p}<0.05)$. At the same time students with round back demonstrated the worst result $2359.02 \mathrm{~m}(\mathrm{~S}=361.42$ $\mathrm{m})$. It corresponds to the lowest level of general endurance $(\mathrm{p}<0.05)$, comparing with students with normal posture.

Testing resulted in statistically significant distinctions in indicators of students with normal posture $(9.58 \mathrm{~s}$., $\mathrm{S}=0.59)$ and students with round back $(10.05 \mathrm{~s} ., \mathrm{S}=0.48)(\mathrm{p}<0.05)$. At the same time students with scoliosis back showed middle level of dexterity ( $9.77 \mathrm{~s} ., \mathrm{S}=0.63$ and $9.71 \mathrm{~s}$., $\mathrm{S}=0.63)$. It should also be noted that these values did not statistically confidently differ from indicators of students with normal posture ( $p>0.05)$.

Table 3

Physical fitness indicators of students with different posture abnormalities $(n=250)$

\begin{tabular}{|l|c|c|c|c|c|c|c|c|}
\hline \multirow{2}{*}{ Description of test } & \multicolumn{7}{c|}{ Posture type } \\
\cline { 2 - 10 } & \multicolumn{2}{|c|}{$\begin{array}{c}\text { Normal posture } \\
(\mathrm{n}=38)\end{array}$} & \multicolumn{2}{c|}{$\begin{array}{c}\text { Scoliosis posture } \\
(\mathrm{n}=91)\end{array}$} & $\begin{array}{c}\text { Round back } \\
(\mathrm{n}=61)\end{array}$ & \multicolumn{2}{c|}{$\begin{array}{c}\text { Slouching back } \\
(\mathrm{n}=60)\end{array}$} \\
\cline { 2 - 11 } & $\bar{x}$ & $\mathrm{~S}$ & $\bar{x}$ & $\mathrm{~S}$ & $\bar{x}$ & $\mathrm{~S}$ & $\bar{x}$ & $\mathrm{~S}$ \\
\hline 12 minutes Cooper's test of walk and run, & 256711 & 317.99 & $2467.58^{*}$ & 357.18 & $2359.02 * 361.42$ & $2440.83 *$ & 283.51 \\
\hline Shuttle run «4 x 9», multiple passing of & 9.58 & 0.59 & 10.01 & 0.59 & $10.05^{*}$ & 0.48 & 10.0 & 0.72 \\
\hline one and the same distance, sec. & & & & & & & & \\
\hline
\end{tabular}




\begin{tabular}{|c|c|c|c|c|c|c|c|c|}
\hline $\begin{array}{l}\text { Initial position (i.p.): hanging with seizing } \\
\text { from above, legs are closed; chin ups } \\
\text { above bar, quantity of times }\end{array}$ & 15.11 & 2.26 & $13.35^{*}$ & 2.00 & $10.30^{*}$ & 1.54 & $12.18^{*}$ & 1.82 \\
\hline $\begin{array}{l}\text { I.p.: lying on back with legs bent in knees } \\
\text { and arms behind head. Rising in sitting } \\
\text { position, quantity of times per } 1 \text { minute. }\end{array}$ & 50.08 & 5.46 & $45.03 *$ & 7.23 & $37.92 *$ & 3.02 & $41.32 *$ & 6.09 \\
\hline $\begin{array}{l}\text { I.p. - sitting position. Maximally bend } \\
\text { forward with arms stretched also } \\
\text { forward, cm }\end{array}$ & 3.53 & 0.67 & 3.31 & 0.56 & $2.21^{*}$ & 0.33 & 3.32 & 0.41 \\
\hline $\begin{array}{l}\text { I.p. lying on abdomen with arms behind } \\
\text { head. Rising and keeping of shoulder } \\
\text { girdle, sec. }\end{array}$ & 90.08 & 9.04 & $60.71 *$ & 10.88 & $50.80^{*}$ & 3.45 & $58.77 *$ & 11.16 \\
\hline
\end{tabular}

Notes: ${ }^{*}-\mathrm{p}<0.05$ in comparison with indicators of students with normal postures.

\section{Discussion}

Results of our researches supplemented the data of other specialists [7, 13, 21, 24]. Besides, they confirmed the conception of V.A. Kashuba et al. [4-6] about prophylaxis approaches to students' physical education.

The received data witness that indicators of dynamic power endurance of shoulder girdle and back muscles of students with normal posture correspond to level above middle (15.11 times, $S=2.26$ ). It is statistically confidently higher than in students with round back ( 10.30 times, $\mathrm{S}=1.54$; level below middle) and students with scoliosis posture (13.35 times, $\mathrm{S}=2$ ). Power endurance of shoulder girdle and back muscles of students with round back and scoliosis posture corresponded to middle level $(\mathrm{p}<0.05)$.

Statistically confident differences between static power endurance of students with normal posture $(90.08 \mathrm{~s}$., $\mathrm{S}=9.04)$, scoliosis posture (60.71 s., $\mathrm{S}=10.88)$, round back (50.80 s., $\mathrm{S}=3.45)$ and slouching back (58.77 s.., $\mathrm{S}=11.16)$ $(\mathrm{p}<0.05)$ are rather substantial.

For assessment of backbone flexibility, hip joints' mobility and elasticity of hamstrings we used test "bending of torso from sitting position". Analysis of this test's results showed low level of this indicator in students with all types of posture. For example in students with normal posture this indicator was, in average, $3.53 \mathrm{~cm}(\mathrm{~S}=0.67)$, with scoliosis posture $-3.31 \mathrm{~cm}(\mathrm{~S}=0.56)$, with slouching back $-3.32 \mathrm{~cm}(\mathrm{~S}=0.41)$. With it, it should be noted that these indicators had no statistically significant distinctions $(\mathrm{p}>0.05)$. At the same time students with round back showed the lowest result $2.21 \mathrm{~cm}(\mathrm{~S}=0.33 \mathrm{~cm})(\mathrm{p}<0.05)$.

\section{Conclusions:}

1. Recent decade in Ukraine there have been observed reduction of students' health that is conditioned by a number of objective and subjective reasons: low social-economical level of life of most of students; conditions of educational functioning; deficit of students motor functioning. As a result - increase of students with functional disorders of muscular skeletal apparatus.

2. We have determined the types of posture abnormalities of students: scoliosis posture was registered in $36.4 \%$ of the tested; slouching back $-24 \%$ of students; round back $-24.4 \%$. Also attracts attention the fact that only $15.2 \%$ of students have normal posture. Increasing of quantity of students with functional disorders of muscular skeletal apparatus creates a problem situation. This potentially unfavorable state earlier or later inevitably results in weakening of organism's functional potentials. 
3. Express control of bio-geometric profile of students (5 indicators in frontal and 6 indicators in sagittal planes) points at the fact that $63.33 \%$ of the tested with normal posture have middle level of posture state. They are in the so-called "risk zone". In the future they can have functional disorders of muscular skeletal apparatus. It should also be noted that students with low level of posture's bio-geometrical profile (scoliosis posture $-43.33 \%$; round back- 23 . $33 \%$; slouching back- $22.73 \%$ ) are in the so-called pre-morbid state of MSA.

4. We detected low flexibility of backbone, mobility of hip joints and elasticity of hamstrings. Students with normal posture had this indicator, equal, in average, to $3.61 \mathrm{~cm}(\mathrm{~S}=4.18)$, students with slouching back $-2.77 \mathrm{~cm}$ $(\mathrm{S}=2.81)$, with round back $-2.21 \mathrm{~cm}(\mathrm{~S}=1.43)$; students with scoliosis posture had $2.19 \mathrm{~cm}(\mathrm{~S}=2.55)$. With it, it should be noted that the above mentioned indicators had no statistically significant distinctions $(\mathrm{p}>0.05)$.

5. Indicators of dynamic power endurance of shoulder girdle and back muscles of students with normal posture correspond to above middle level and are 15.11 times, $(S=3.94)$. It is statistically confidently higher than indicators of students with round back (10.30 times, $\mathrm{S}=2.40$; - level below middle); students with scoliosis posture (13.35 times, $\mathrm{S}=4.49$ ) and round back (12.18 times, $\mathrm{S}=3.82)$. It is very important that with registration of static power endurance statistically confident distinctions were found in students with scoliosis posture $(60.71 \mathrm{sec}$., $\mathrm{S}=10.88)$, round back (50.80 sec., $\mathrm{S}=3.45)$, slouching back (58.77 sec., $\mathrm{S}=11.16)$ in comparison with students with normal posture (90.08 sec., $\mathrm{S}=9.04)(\mathrm{p}<0.05)$.

The prospects of further researches are connected with working out of technology of not fixed MSA disorders' prophylaxis in students, in process of their physical education.

\section{Conflict of interests}

The author declares that there is no conflict of interests.

\section{References}

1. Belikova ZhA. Uprazhneniia khatkha-jogi kak sredstvo korrekcii deformacii pozvonochnika studentov special'nykh medicinskikh grupp s narusheniiami osanki. Cand. Diss. [Hatha yoga exercises as mean of backbone deformation's correction of special health groups' students with posture abnormalities. Cand. Diss.], Belgorod, 2012. (in Russian)

2. Zabalueva TV. Pedagogicheskie aspekty formirovaniia vozrastnoj osanki cheloveka [Pedagogic aspects of formation of human age posture]. Uchenye zapiski universiteta imeni P.F. Lesgafta, 2009;5:27 - 31. (in Russian)

3. Isaeva OV. Differencirovannye podkhody $k$ ozdorovleniiu studentov 16-17 let $s$ narusheniiami osanki $v$ processe fizicheskogo vospitaniia. Cand. Diss. [Differentiated approaches to health improvement of 16-17 years' age students with posture abnormalities in process of physical education. Cand. Diss.], Ivanovo, 2015. (in Russian)

4. Kashuba VA, Bibik R, Nosova N. Kontrol' sostoianiia prostranstvennoj organizacii tela cheloveka v processe fizicheskogo vospitaniia [Control of human body space organization in process of physical education]. Molodizhnij naukovij visnik Volins'kogo nacional'nogo universitetu imeni Lesi Ukrainki. 2012;7:10-19. (in Russian)

5. Kashuba VA, Dudko MV. Sovremennye podkhody, metodiki i tekhnologii k formirovaniiu zdorovogo obraza zhizni studentov $\mathrm{v}$ processe fizicheskogo vospitaniia [Modern approaches to, methodic and technologies of students' healthy life style formation in process of physical education]. Fizichne vikhovannia, sport $i$ kul'tura zdorov'ia u suchasnomu suspil'stvi. 2015;1:52 - 57. (in Russian)

6. Kashuba VA, Martyniuk OA. K voprosu ispol'zovaniia korekcionno-profilakticheskikh programm v processe fizicheskogo vospitaniia studentok s razlichnymi narusheniiami prostranstvennoj organizacii tela [On the question of usage of correction-prevention programs in physical education of girl students with different disorders of body space organization]. Naukovij chasopis NPU im. M.P. Dragomanova, 2013;1(27):28-35. (in Russian)

7. Kashuba VA, Ivchatova T, Sergienko K. K voprosu izmeneniia prostranstvennoj organizacii tela cheloveka v processe fizicheskogo vospitaniia s ispol'zovaniem komp'iuternykh tekhnologij [On the question of change of human body space organization in physical education with the help of computer technologies]. Sportivnij visnik Pridniprov'ia. 2014;1:42-45. (in Russian)

8. Kolos MA. Korekciia funkcional'nikh porushen' oporno-rukhovogo aparatu studentov v procesi fizichnogo 
vikhovannia. Cand. Diss. [Correction of functional disorders of students' muscular skeletal apparatus in process of physical education. Cand. Diss.], Dnipropenrovsk, 2010. (in Ukrainian)

9. Martyniuk OA. Korrekciia narushenij prostranstvennoj organizacii tela studentok v processe fizicheskogo vospitaniia. Cand. Diss. [Correction of disorders of girl students' body space organization in process of physical education. Cand. Diss.], Kiev, 2011. (in Russian)

10. Nosova NL. Kontrol' prostorovoi organizacii tila shkoliariv u procesi fizichnogo vikhovannia. Cand. Diss. [Control of schoolchildren's body space organization in process of physical education. Cand. Diss.], Kiev, 2008. (in Ukrainian)

11. Retivykh IuI. Metodika korrekcii narushenij osanki studentov sredstvami ozdorovitel'noj fizicheskoj kul'tury na osnove ucheta vidov i stepeni deformacij pozvonochnika. Cand. Diss. [Methodic of correction of students' postures by means of health related physical culture on the base of registration of kinds and degree of backbone deformation. Cand. Diss.], Volgograd, 2009. (in Russian)

12. Temchenko VA, Burko VL, Konik GA. Organizaciia upravleniia fizicheskoj kul'turoj i sportom v vysshem uchebnom zavedenii [Organization of management of physical culture and sports in higher educational establishment]. II regional'na naukova konferenciia "Strategichne upravlinnia rozvitkom galuzi Fizichna kul'tura i sport", 14 grudnia 2013 r., Kharkiv [II regional scientific conference "Strategic management of development of Physical culture and sports' branch". December 14th, 2013, Kharkiv], Kharkiv, HDAFK; 2014. p. 16-18. (in Russian)

13. Futornyj SM. Zdorov'esberegaiushchie tekhnologii v processe fizicheskogo vospitaniia studencheskoj molodezhi [Health related technologies in process of physical education of students], Kiev: Poligrafservis, 2014. (in Russian)

14. Erdenko DV. Metodika ispol'zovaniia vostochnoj gimnastiki pri narusheniiakh osanki studentok gumanitarnykh vuzov. Cand. Diss. [Methodic of application of oriental gymnastic with posture's abnormalities of humanitarian HEEs' girl students. Cand. Diss], Moscow, 2009. (in Russian)

15. Iumasheva LI. Korekciia porushen' postavi studentiv muzichnogo vishchogo navchal'nogo zakladu u procesi fizichnogo vikhovannia. Cand. Diss. [Posture's corrections of musical higher educational establishment's students in process of physical education. Cand. Diss], Kiev, 2007. (in Ukrainian)

16. Iakovenko DV. Ozdorovitel'naia fizicheskaia kul'tura studentov s osteokhondrozom pozvonochnika na osnove kompleksnykh korrigiruiushchikh vozdejstvij. Cand. Diss. [Health related physical culture of students with backbone osteochondrosis on the base of complex correcting impacts. Cand. Diss.], Sankt Petersburg, 2009. (in Russian)

17. AbouHassan J, Milosavljevic S, Carman A. Can postural modification reduce kinetic and kinematic loading during the bowing postures of Islamic prayer? Ergonomics. 2010;53(12):1446-1454.

18. Andrejeva Julija, Mockiene Asta, Zukauskiene Milda. Fatigue and faulty posture connection among children, diagnosed with dysarthria. Pedagogics, psychology, medical-biological problems of physical training and sports. 2015;8:75-81. http://dx.doi.org/10.15561/18189172.2015.0810

19. Andrews DM, Fiedler KM, Weir PL, Callaghan JP. The effect of posture category salience on decision times and errors when using observation-based posture assessment methods. Ergonomics. 2012;55(12):1548-58.

20. Boak A, Hamilton HA, Adlaf EM, Beitchman JH, Wolfe D, Mann RE. The mental health and well-being of Ontario students. CAMH Research Document. 2014;38:213-244.

21. Bothmer M, Fridlund B. Gender differences in health habits and in motivation for a healthy lifestyle among Swedish university students. Nursing and Health Sciences. 2005;7:107-110.

22. Cavalheri V, Camillo CA, Brunetto AF, Probst VS, Cipulo Ramos EM, Pitta F. Effects of arm bracing posture on respiratory muscle strength and pulmonary function in patients with chronic obstructive pulmonary disease. Revista Portuguesa de Pneumologia (English Edition). 2010;16(6):887-91.

23. Futornyi S. Actual issues of improving the process of student's physical education through the application of modern health-saving technologies. Molodizhnij naukovij visnik nacional'nogo universitetu imeni Lesi Ukrainki. 2014;14:26-30. 
24. Gorelov A.A., Kondakov V.L., Belikova Zh.A. About necessity of use of Hatha Yoga exercises for correction of deformation of students' spine of special medical groups with violations of posture. Physical education of students, 2013, vol.2, pp. 35-44. http://dx.doi.org/10.6084/m9.figshare. 156378

25. Hong Y, Fong DT-P, Li JX. The effect of school bag design and load on spinal posture during stair use by children. Ergonomics. 2011;54(12):1207-13.

26. Kalinichenko IO, Dyachenko YL. State changes in posture and arch of the foot in children aged $4-6$ years with hypermobility of the joints under the influence of rehabilitation activities in schools. Pedagogics, psychology, medical-biological problems of physical training and sports, 2013;8:26-30. http://dx.doi.org/10.6084/m9.figshare.745781

27. Litvinenko Y.V., Niznikowski Tomasz, Boloban V.N. Evaluation of the kinematic structure of indicators key elements of sports equipment exercise by postural orientation movements. Physical education of students, 2014;6:29-36. http://dx.doi.org/10.15561/20755279.2014.0606

28. Mani R, Milosavljevic S, Sullivan SJ. Control of posture during tasks representing common work-related postures - a reliability study. Ergonomics. 2015;3;58(6):980-989.

29. Torlakovic A, Muftic M, Radjo I, Talovic M, Mahmutovic I. Evolution of Sports-medical Team Management in the Program of Posture Correction in Children. Materia Socio Medica. 2014;26(2):104.

30. Źukowska Hanna, Szark-Eckardt Mirosława, Muszkieta Radosław, Iermakova TS. Characteristics of body posture in the sagittal plane and fitness of first-form pupils from rural areas. Pedagogics, psychology, medicalbiological problems of physical training and sports, 2014;7:50-60. http://dx.doi.org/10.6084/m9.figshare.1015583

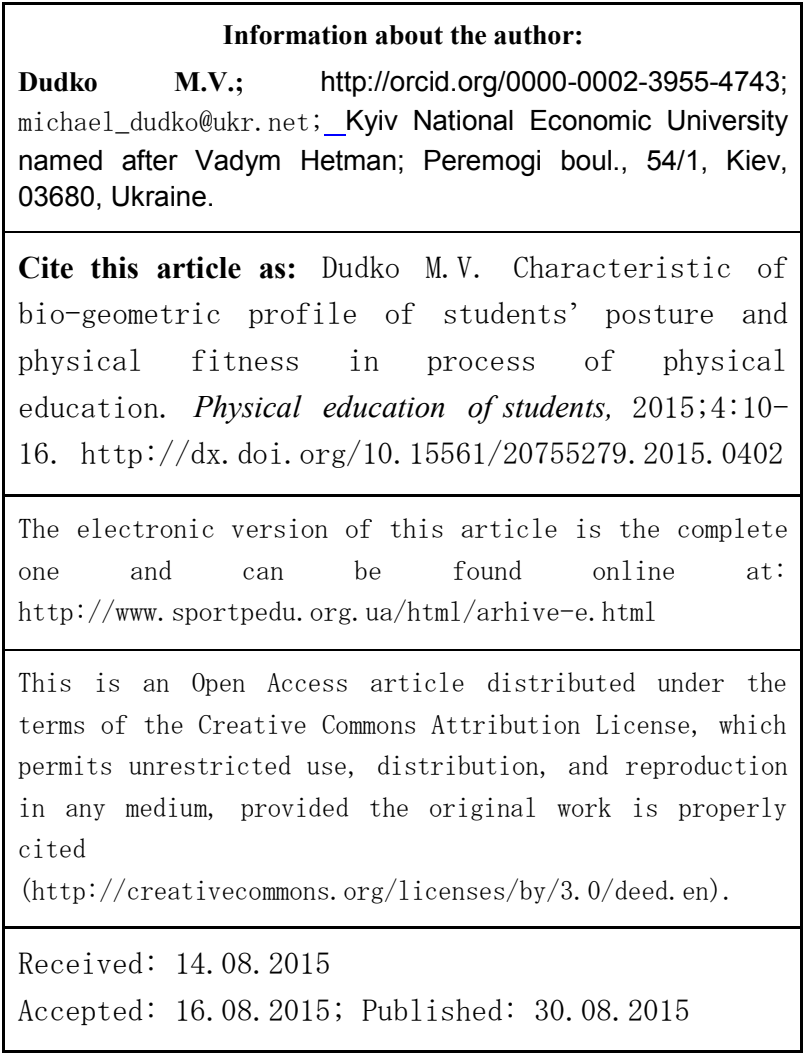




\title{
MODEL CHARACTERISTICS OF AVERAGE SKILL BOXERS' COMPETITION FUNCTIONING
}

\author{
Martsiv V.P.
}

Lviv State University of Physical Culture

\begin{abstract}
Purpose: analysis of competition functioning of average skill boxers. Material: 28 fights of boxersstudents have been analyzed. The following coefficients have been determined: effectiveness of punches, reliability of defense. The fights were conducted by formula: 3 rounds ( 3 minutes - every round). Results: models characteristics of boxers for stage of specialized basic training have been worked out. Correlations between indicators of specialized and general exercises have been determined. It has been established that sportsmanship of boxers manifests as increase of punches' density in a fight. It has also been found that increase of coefficient of punches' effectiveness results in expansion of arsenal of technical-tactic actions. Importance of consideration of standard specialized loads has been confirmed. Conclusions: we have recommended means to be applied in training process at this stage of training. On the base of our previous researches we have made recommendations on complex assessment of sportsmen-students' skillfulness. Besides, we have shown approaches to improvement of different sides of sportsmen's fitness.
\end{abstract}

Key words: boxing, indicator, fight, punches, competition functioning, achievement of results.

\section{Introduction}

Analysis of sport functioning show, that, from the point of view of systemic approach, competitions are main and primary component. Trainings are secondary component, which is a mean of preparation for participation in competitions $[1,7,8,14,20,21,29,35]$. That is why study of competition functioning's requirements, appropriate structure and content of training process is one of the most topical tasks of sports training's theory and methodic $[9,10,16,27,28,34]$.

Many authors [1, 7, 9, 27, 35] note the demand in studying of modern requirements, influencing on competition functioning. The result of such approach is creation of adequate to these requirements technology of qualified boxers' training. From these positions boxer's sport functioning is directed on victory in fight with opponent. The victory is ensured by required level of technical-tactic, physical and psychic fitness. Such fitness is conditioned by individual features of sportsmen; by quality and effectiveness of training process [24, 31, 32, $33,36,37]$.

The researches of elite boxers' competition functioning permitted to mark out comparative characteristics of fights, which were conducted by different formulas of competition functioning and in different periods of development of amateur boxing $[8,11,18]$. On the base of these data characteristics of average skill boxers were outlined. It is purposeful to receive such characteristics by simulation of fights and determination of certain model indicators.

Purpose, tasks of the work, material and methods

The purpose of the research: is to analyze competition functioning of average skill boxers and develop sportsmen's model characteristics for stage of specialized basic training.

The tasks of the research:

- To receive indicators of competition functioning of average skill boxers at stage of specialized basic training;

- To compare indicators of average skill boxers' competition functioning with the best results of elite boxers', received in previous researches;

- On the base of our previous researches to work out recommendations on complex assessment of sportsmen-students' skillfulness. Besides, it was required to show approaches to perfection of different sides of sportsmen's fitness.

Organization and methodic of the research:

We analyzed 28 fights of average skill boxers (first sport grade and candidate masters of sports). All they were students of Lviv State University of Physical Culture. We carried out video recording of boxers'

(C) Martsiv V.P., 2015

http://dx.doi.org/10.15561/20755279.2015.0303 
performances on University Games of Lviv region. When watching video-records we assessed the following technical tactic indicators of competition functioning:

1) Total quantity of punches per fight;

2) Quantity of punches per round;

3) Quantity of punches per minute;

4) Quantity of successful punches;

5) Quantity of unsuccessful punches;

6) Density of technical actions - relation of accurate punches (successful) to duration of fight (in minutes);

7) Coefficient of punches' effectiveness - relation of quantity of accurate punches to total quantity of punches per fight;

8) Coefficient of reliability of defense - relation of unsuccessful punches to total quantity of punches per fight;

The received data were processed with methods of mathematical statistic with the help of standard computer program, "Statistica 7".

Results of the researches

Analysis of video-records of boxers' fights (see table 1) permitted to receive indicators of average skill boxers' competition functioning. For comparison, in table1 we give also indicators of elite boxers, received by us as a result of fights at London Olympic games 2012 [8].

Table 1

Indicators of average skill and elite boxers' competition functioning

\begin{tabular}{|c|c|c|c|}
\hline & Indicators of competition functioning & Elite boxers & Average skill boxers \\
\hline № & & 1 & 2 \\
\hline 1 & Density of fight (total quantity of punches per fight) & 174.17 & 40.14 \\
\hline 2 & Quantity of punches per round & 58.06 & 13.38 \\
\hline 3 & Quantity of punches per minute & 19.35 & 4.46 \\
\hline 4 & Quantity of successful punches & 104.63 & 20.68 \\
\hline 5 & Quantity of unsuccessful punches & 70.03 & 19.46 \\
\hline 6 & DTA (density of technical actions) & 35.2 & 7.2 \\
\hline 7 & CPE (coefficient of punches' effectiveness) & 1.75 & 0.48 \\
\hline 8 & CDR (coefficient of defense reliability) & 0.62 & 0.31 \\
\hline 9 & Interval of attack & 10.53 & 5.31 \\
\hline
\end{tabular}


Difference between indicators of attack and defense actions of both groups' boxers is the following: first grade boxers and candidate masters of sports (average skill boxers) significantly lag behind boxers of world combined teams by indicators of attack and defense actions. This fact is obvious and does not require any confirmations.

Indicators of attack and defense actions of elite boxers can be considered to be model characteristics (see table 1). Among elite boxers combined team of Ukraine should be noted, which in team standing won the first place. In particular these boxers were: Pavel Ishchenko (up to $56 \mathrm{~kg}$ ), Valiliy Lomachenko (up to $60 \mathrm{~kg}$ ), Denis Berynchyk (up to $64 \mathrm{~kg}$ ), Taras Shelestiuk (up to $69 \mathrm{~kg}$ ), Yevgeny Khytrov (up to $75 \mathrm{~kg}$ ), Aleksandr Gvozdyk (up to $81 \mathrm{~kg}$ ), Aleksandr Usyk (up to $91 \mathrm{~kg}$ ). Five sportsmen of the team took prize places. Indicators of these sportsmen are bench marks for sportsmen, who are on stage of specialized basic training. In compliance with these indicators it is necessary to build training of sportsmen-students. In their turn, indicators of sportsmenstudents are bench marks for less qualified sportsmen. Here it would be appropriate to present the data of known specialists, who delivered quite in detail approaches to application of model characteristics of the best sportsmen at different stages of boxers' training [4-6, 18, 19].

Among such researches there are works, fulfilled in context of the present research [22, 23]. Results of these researches were used in training of sportsmen-students:

1. Assessment of influence of different factors on power of punch as criterion of competition functioning's effectiveness. It is recommended to train maximal and explosive power of all parts of sportsmen's bodies during fulfillment of general warming up exercises with further transfer of physical qualities in fulfillment of special exercises [23].

2. In training of heavy weight boxers it is necessary to pay more attention to training of quantitative parameters: physical condition; training of maximal strength and speed power; endurance [25].

3. Approaches to usage model characteristics in training process, delivered in works of specialists $[4,5,6$, 26]. In these works attention is attracted to level of general physical fitness and special fitness. It is necessary to consider that factor of physical and special fitness of elite boxers does not change depending on stage of training. At every stage these factors do not depend on each other and are separate sides of general and special fitness. It is recommended to doze evenly load on all factors when dozing loads. It is recommended to use integral marks of different sides of fitness (technical-tactic, psychic, general and special physical fitness).

Besides, in training of sportsmen we used results of our previous researches and appropriate recommendations:

1. Determination of responses of boxers' anticipation under influence of standard specialized loads. In main part of training session boxers improved individual 4-5 punches' series on boxing bag with the task to strike as strongly and quickly as possible (load - 9 rounds, 3 minutes each, with interval 1 minute of rest). After finishing it, boxers fulfilled power exercises with barbell rod and filled ball. We determined regularities of manifestation of every response type in a group of sportsmen and envisaged the ways of their application as criteria for assessment of boxers' psychological condition [18].

2. Increase of sportsmen's skillfulness is manifested as increasing of punches density in a fight. Increase of punches' effectiveness coefficient results in widening of effective technical-tactic actions [20].

3. Correlation between indicators of special and general exercises of sportsmen implied the following: there are confident statistical correlations: a) between power of punches and speed of single movement; b) between power of kicks and indicators of maximal force of muscles (thrust); c) between speed of punches (kicks) and indicators of push of balls ( $300 \mathrm{~g}$ mass); d) between indicators of speed of movement step in combat stance and indicators of punches' speed; e) between indicators of punches' frequency and indicators of frequency of movement (maneuvering) on feet. We also determined means, which it would be purposeful to apply in training process at this stage [22]

\section{Discussion}

The received results confirm the data $\mathrm{f}$ other authors [27, 19, 35] about importance of orientation of boxers' training on model indicators of more qualified sportsmen. Our researches were fulfilled in compliance with recommendations of well known specialists in boxing $[4,5,6,26]$. The authors show potentials of simulation of different sides of sportsmen's fitness. 
The received results and our earlier researches are in good agreement with approaches of specialists in context of consideration of the following: boxer's bent to certain style of fight $[2,3,15]$; degree of sportsmen's readiness to training session, organism's response to load and activation of recreational processes [11, 12, 30]; degree of training tension, assessment of changes of workability and responsive properties of cardio-respiratory systems [13]; possibility of usage of specialized variable means and methods, permitting to form base of motor conditions and skills [17].

The received results expand general ideas about approaches to training of sportsmen-students with the help of model indicators. They show demand in consideration of anticipation reactions' indicators under influence of standard specialized loads in training process. By results of the researches we found correlation between indicators of special and general exercises for certain stages of training. The obtained coefficients of punches' effectiveness and defense reliability give more general picture about fitness of sportsmen-students.

\section{Conclusions:}

Analysis of literature sources witnesses about topicality of further studying of competition functioning of qualified amateur boxers and working out of model characteristics.

On the base of received by us indicators of elite boxers' sport results we created model characteristics for average skill boxers (first sport grade and candidate masters of sports). Such characteristics are recommended to be used in training of sportsmen at stage of specialized basic training.

\section{Acknowledgement}

The present work is a component of topic of combined plan of scientific-research works in sphere of physical culture and sports for 2011-2015 "Formation of individual style of competition functioning at stage of specialized basic training"; "Individualization of training process of elite martial arts sportsmen".

\section{Conflict of interests}

The author declares that there is no conflict of interests.

\section{References:}

1. Akopian AO, Novikov AA. Analiz kharakteristik sorevnovatel'noj deiatel'nosti kak faktor postroeniia trenirovochnykh processa $v$ edinoborstvakh [Analysis of competition functioning characteristics as factor of construction of training process in martial arts], Moscow: VNIIFK; 1985 (in Russian).

2. Aksutin VV, Korobeynikov GV. Study of special capacity in boxers with different styles of fight. Physical Education of Students, 2014;5:3-7. http://dx.doi.org/10.15561/20755279.2014.0501

3. Aksutin VV, Korobeynikov GV. Psychophysiological states and special performance of boxers with different styles of fight. Pedagogics, psychology, medical-biological problems of physical training and sports, 2014;12:3-6. http://dx.doi.org/10.15561/18189172.2014.1201

4. Gas'kov AV, Kuz'min VA. Modelirovanie struktury trenirovochnykh sredstv obshchej i special'noj podgotovki kvalificirovannykh bokserov [Simulation of structure of training means for general and special training of qualified boxers]. Physical education of students, 2011;6:22 - 26.

5. Gas'kov AV, Kuz'min VA, Putin LP. Razrabotka model'nykh kharakteristik trenirovochnoj deiatel'nosti v edinoborstvakh (na primere boksa) [Working out of model characteristics of training functioning in martial arts (on example of boxing)]. Physical education of students, 2010;1:15 - 18.

6. Gas'kov AV, Kuz'min VA, Putin LP. Tekhnologiia registracii trenirovochnykh nagruzok v edinoborstvakh (na primere boksa) [Technology of training loads' registration in martial arts (on example of boxing)]. Physical education of students, 2010;1:19 - 23.

7. Demin V.A., Piloian R.A. Sportivnaia deiatel'nost' v teorii funkcional'noj sistemy [Sport functioning in theory of functional system]. Vsemirnyj nauchnyj kongress "Pedagogika, psikhologiia: Sport v sovremennom obshchestve" [All-world scientific congress "Pedagogic, psychology: sports in modern society"], Moscow, GTSOLIFK;1980. p. 192-193 (in Russian).

8. Dzheroian GA. Takticheskaia podgotovka bokserov [Training of boxers' tactic], Moscow: Physical Culture and Sport; 1970 (in Russian).

9. Dzheroian GO. Individual'nye manery vedeniia boia i sposoby protivodejstvovat' [Individual styles of fighting and methods of counteracting them], Moscow: Physical Culture and Sport; 1979 (in Russian). 
10. Keller VS, Platonov VM. Teoretiko-metodichni osnovi pidgotovki sportsmeniv [Theoretical-methodic principles of sportsmen's training], Lviv: Ukrainian sports association; 1993. (in Ukrainian).

11. Kiprych SV. Control system improvement of qualified boxers based assessment system change reaction cardiorespiratory during the immediate preparation for competition. Physical Education of Students, 2014;4:26-31. http://dx.doi.org/10.6084/m9.figshare.996011

12. Kiprich SB, Berinchik DY. Specific descriptions of functional providing of the special endurance of boxers. Pedagogics, psychology, medical-biological problems of physical training and sports, 2015;3:20-27. http://dx.doi.org/10.15561/18189172.2015.0304

13. Kiprych SV, Donets AV, Makhdi Omar Ali. Improvement of management by training process of boxers at a stage of direct preparation for competitions. Physical Education of Students, 2013;6:20-24. http://dx.doi.org/10.6084/m9.figshare.840495

14. Kiselev VA. Sovershenstvovanie sportivnoj podgotovki vysokokvalificirovannykh bokserov [Perfection of sport training of elite boxers], Moscow: Physical Culture and Sport; 2006. (in Russian).

15. Korobeynikov GV, Aksutin VV, Smoliar II. Connection of boxers' combat styles with psycho-physiological characteristics. Pedagogics, psychology, medical-biological problems of physical training and sports, 2015;9:33-37. http://dx.doi.org/10.15561/18189172.2015.0905

16. Linec' MM. Osnovi metodiki rozvitku rukhovikh iakostej [Principles of methodic of motor skills' training]. Lviv: Shtabar; 1997. (in Ukrainian).

17. Liu Yong Qiang. Experimental substantiation of methodic of 11-13 years old boxers' coordination development. Pedagogics, psychology, medical-biological problems of physical training and sports, 2015;6:14-22. http://dx.doi.org/10.15561/18189172.2015.0603

18. Martsiv VP. Comparative analysis of competitive activity parameters of amateur boxers high qualification. Physical Education of Students, 2014;6:41-44. http://dx.doi.org/10.15561/20755279.2014.0608

19. Martsiv VP. Comparative analysis of competitive activity parameters of amateur boxers high qualification. Physical Education of Students, 2014;6:41-44. http://dx.doi.org/10.15561/20755279.2014.0608

20. Matvienko IS. Opredelenie optimal'noj tekhnologi i modeli otbora detej na nachal'nom etape mnogoletnego usovershenstvovaniia [Determination of optimal technology and selection of children at initial stage of many years' perfection]. Pedagogics, psychology, medical-biological problems of physical training and sports,2010;4:90 - 93.

21. Matveev LP. Sorevnovatel'naia deiatel'nost' sportsmena i sistema sportivnykh sorevnovanij [Competition functioning of a sportsman and system of sport competitions], Moscow; 1996. (in Russian).

22. Nykytenko AO, Nikitenko SA, Busol VV, Nykytenko AA, Velychkovych MR, Martciv VP. Intercommunications of indexes of speed and power qualities of sportsmen single combat on the stage of the specialized base preparation. Pedagogics, psychology, medical-biological problems of physical training and sports, 2013;1:49-55. http://dx.doi.org/10.6084/m9.figshare.106939

23. Nikitenko SA, Nikitenko AA, Nikitenko AA. Faktory, kotorye vliiaiut na silu udarov bokserov i futbolistov na etape predvaritel'noj bazovoj podgotovki [Factors, which influence on boxers' and football players' kick power at stage of initial basic training]. Pedagogics, psychology, medical-biological problems of physical training and sports, 2011;2:88 - 91 .

24. Nikiforov Iu. Trenirovka olimpijskogo chempiona Borisa Kuznecova [Training of Olympic champion Boris Kuznetsov]. In: Boxing. Moscow: Physical Culture and Sport; 1978. (in Russian).

25. Ost'ianov VN, Grib AI, Kopachko OV. Sorevnovatel'naia deiatel'nost' bokserov tiazhelykh i legkikh vesovykh kategorij [Competition functioning of heavy and light weight categories' boxers]. Pedagogics, psychology, medical-biological problems of physical training and sports, 2010;12:94 - 98.

26. Pavelec O.J., Ostyanov V.N., Maydanyuk O.V., Model features as the basis of preparation of boxers individualization principal level (elite). Pedagogics, psychology, medical-biological problems of physical training and sports, 2013;10:46-49. http://dx.doi.org/10.6084/m9.figshare.775329

27. Petukhov VA. Issledovanie plotnosti $i$ effektivnosti udarnykh dejstvij bokserov $i$ metodika ikh sovershenstvovaniia. Cand. Diss. [Study of density and effectiveness of boxers' attacks and methodic of their perfection. Cand. DissMoscow; 1970. (in Russian). 
28. Platonov VN. Sistema podgotovki sportsmenov v olimpijskom sporte [Systemof sportsmen's training in Olympic sports], Kiev: Olympic Literature; 2004. (in Russian).

29. Sokolov V. Iz opyta podgotovki k Kh1Kh Olimpijskim igram [Experience of training to XIX Olympic games], Moscow: Physical Culture and Sport; 1975. (in Russian).

30. Syshko DV, Kroviakov VF, Savina KD, Syshko GD. Osobennosti reguliacii serdechnogo ritma bokserov razlichnoj kvalifikacii [Specific features of regulation of heart beats of different qualification boxers]. Physical education of students, 2011;6:96 - 98.

31. Taratorin NN. Boks [Boxing], Moscow: Terra-Sport; 1998; (in Russian).

32. Filimonov VI. Boks [Boxing], Moscow, INSAN; 2001. (in Russian).

33. Frolov EP, Vartanov GM, Ispandiiarov MI. Metodika izucheniia sorevnovatel'noj deiatel'nosti bokserov [Methodic of study of boxers' competition functioning]. Moscow: RIOVNIIFK; 1986. (in Russian).

34. Shiriaev AG. Boks [Boxing], Sankt Petersburg: Chaton; 2002. (in Russian).

35. Shcherbakov SI. Analiz sorevnovatel'noj deiatel'nosti bokserov vysokoj kvalifikacii v sviazi s izmeneniiami formuly vedeniia boia. Cand. Diss. [Analysis of elite boxers' competition functioning in connection of change of fighting formula. Cand. Diss.], Moscow; 2003. (in Russian).

36. Ashkinazi S, Jagiello W, Kalina R. The importance of hand-to-hand fights for determining psychomotor competence of antiterrorists. Arch. Budo, 2005;1:8-12.

37. Chen Y-C, Tseng T-C, Hung T-H, Hsieh CC, Chen F-C, Stoffregen TA. Cognitive and postural precursors of motion sickness in adolescent boxers Gait \& Posture. 2013,38(4):795-799. http://dx.doi.org/10.1016/j.gaitpost.2013.03.023. 


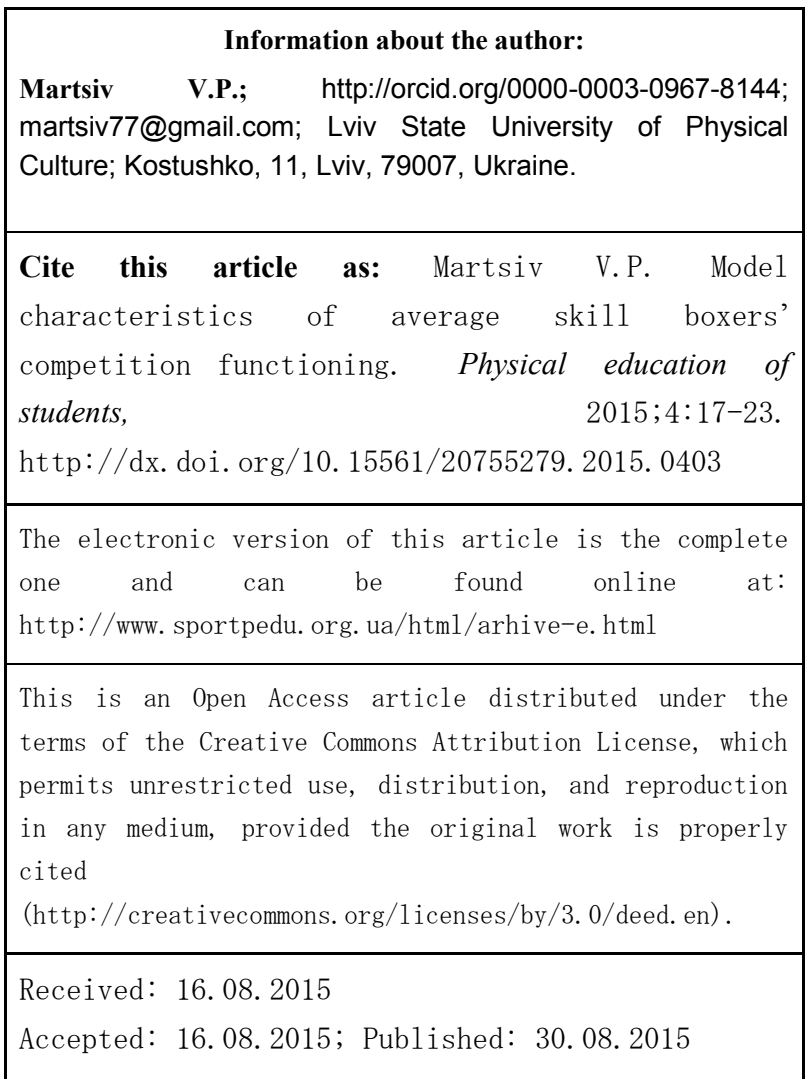




\title{
QUICKNESS AND ENDURANCE FITNESS OF PEDAGOGIC COLLEGE GIRL STUDENTS UNDER INFLUENCE OF CHEER-LEADING
}

\author{
Masliak I.P
}

Kharkiv State Academy of Physical Culture

\begin{abstract}
Purpose: to determine dynamic of quickness and endurance indicators of pedagogic college girl students under influence of cheer-leading. Material: in the research 385 girl students participated, who composed 3 control and 3 experimental groups. Quickness fitness was registered by indicators of 60 meters' run (sec.); latent time of motor response (msec.); run on the sport during $5 \mathrm{sec}$ (quantity of steps); tapping test (quantity of points). Level of endurance fitness was registered by results of 2000 meters' run ( $\mathrm{min})$. Results: the most effective cheer-leading exercises, which positively influence on girl students' endurance, have been determined. The most favorable age periods for training of quickness and endurance under influence of cheer-leading exercises have been found. The higher increment in quickness indicators was registered in 15 years old girls. The most substantial increment of endurance was registered in 16 years old girls. Conclusions: it is recommended to include cheer-leading exercises: basic movements, jump elements, constants, in variable components of girl students' academic training program.
\end{abstract}

Key words: physical education, students, quickness, endurance, cheer-leading.

\section{Introduction}

Physical education is an integral component of teaching, education and vocational training at higher educational establishments [10]. In process of future specialists' training significant attention shall be paid to mastering of professional knowledge and skills, development of physical qualities and formation of healthy life style [15]. Modern students endure much less physical and much higher emotional-psychological loads, stress states, hypodynamia. It results in reduction of adaptation potentials of young people's organisms and increase of morbidity. That is why the problem of increasing of students' physical education effectiveness at the account of introduction of new and non traditional motor functioning's kinds is rather topical.

A number of authors note improvement of students' health and motor fitness at the account of priority usage of volleyball [19, 23], light athletic [1], football [8], body-flex and pilates [20], swimming [17], aqua-fitness [6], futsal [22] in academic training program.

Cheer-leading is one of innovative kinds of motor functioning. Cheer-leading, as a kind of sports, has appeared comparatively not long age and has acquired wide acclaim among USA youth, in European countries and in Ukraine. It has show character, renders different impacts; it is dynamic and can be practiced by wide age range of people [4, 16, 18]. With it cheer-leading does not require special equipment and apparatuses. It is especially important in conditions of social-economical crisis.

A number of authors note in their works positive influence of cheer-leading of pre school age children's physical condition [12]; on physical health, motor fitness and interest to physical culture of secondary schools' pupils $[2,3,13,14]$; physical condition and physical workability of first years girl students of technical university [11]; on formation of wide arsenal of motor skills of higher educational establishments' students [5]; on development of specific physical qualities of college girl students [7, 21].

With it influence of cheer-leading exercises on complex manifestation of college girl students' motor abilities has still been studied insufficiently.

\section{Purpose, tasks of the work, material and methods}

The purpose of the research is to determine dynamic of quickness and endurance indicators of pedagogic college girl students under influence of cheer-leading.

The methods of the research: theoretical analysis and generalization of scientific-methodic literature; pedagogic experiment; pedagogic testing;; methods of mathematical statistic.

Quickness fitness was registered by indicators of 60 meters' run (sec.); latent time of motor response (msec.); run on the sport during $5 \mathrm{sec}$ (quantity of steps); tapping test (quantity of points). Level of endurance fitness was registered by results of 2000 meters' run (min).

(C) Masliak I.P., 2015

http://dx.doi.org/10.15561/20755279.2015.0304 
The researches were conducted on the base of pedagogic college of Kharkov humanitarian-pedagogic institute. 385 first - third years girls students of physical culture profile participated in the researches. They composed 3 control and 3 experimental groups: $1^{\text {st }}$ group $-1^{\text {st }}$ year girl students; $2^{\text {nd }}$ group $-2^{\text {nd }}$ year girl students and $3^{\text {rd }}$ group $-3^{\text {rd }}$ year girl students. All girl students were the members of main and preparatory health group. The research was approved by ethic committee of Kharkov humanitarian pedagogic institute.

In the course of experiment control groups' girl students were trained by traditional physical education program. In variable component of experimental groups' training process cheer-leading exercises were introduced (basic movements, jump elements, constants and so on).

\section{Results of the researches}

Analysis of the received results of quickness testing (see table 1) showed absence of confident distinctions between indicators of girl students of experimental and control groups ( $>0.05)$. Analysis of initial data permitted to detect the absence of definite system of distinctions in results $(p>0.05)$. The exclusion were indicators of motor response and run on the spot, where distinctions in results of $1^{\text {st }}$ and $2^{\text {nd }}$ as well as between $2^{\text {nd }}$ and $3^{\text {rd }}$ groups were confident $(\mathrm{p}<0.05-0.001)$.

Table 1

Quickness indicators of experimental and control groups girl students before experiment

\begin{tabular}{|c|c|c|c|}
\hline \multirow{3}{*}{ Groups } & $\mathrm{I}$ & II & III \\
\hline & \multicolumn{3}{|c|}{ Indicators $\bar{X} \pm \mathrm{m}$} \\
\hline & \multicolumn{3}{|c|}{60 meters' run (sec.) } \\
\hline$n$ & 75 & 108 & 95 \\
\hline Experimental & $10.75 \pm 0.08$ & $10.70 \pm 0.07$ & $10.84 \pm 0.05$ \\
\hline$n$ & 23 & 34 & 50 \\
\hline Control & $10.81 \pm 0.13$ & $10.73 \pm 0.10$ & $10.91 \pm 0.08$ \\
\hline $\mathrm{t}$ & 0.38 & 0.24 & 0.71 \\
\hline \multirow[t]{2}{*}{$\mathrm{p}$} & $>0.05$ & $>0.05$ & $>0.05$ \\
\hline & \multicolumn{3}{|c|}{ Latent time of motor response (msec.) } \\
\hline Experimental & $0.29 \pm 0.00$ & $0.27 \pm 0.00$ & $0.28 \pm 0.00$ \\
\hline Control & $0.29 \pm 0.01$ & $0.27 \pm 0.00$ & $0.28+0.00$ \\
\hline $\mathrm{t}$ & 0.62 & 0.30 & 0.73 \\
\hline \multirow[t]{2}{*}{$\mathrm{p}$} & $>0.05$ & $>0.05$ & $>0.05$ \\
\hline & \multicolumn{3}{|c|}{ Run on the spot (quantity of steps) } \\
\hline Experimental & $18.25 \pm 0.35$ & $17.95 \pm 0.18$ & $17.59 \pm 0.19$ \\
\hline Control & $18.74 \pm 0.38$ & $17.74 \pm 0.28$ & $17.22 \pm 0.27$ \\
\hline $\mathrm{t}$ & 0.94 & 0.65 & 1.10 \\
\hline \multirow[t]{2}{*}{$\mathrm{p}$} & $>0.05$ & $>0.05$ & $>0.05$ \\
\hline & \multicolumn{3}{|c|}{ Tapping test (quantity of points) } \\
\hline Experimental & $68.67 \pm 0.62$ & $66.34+1.05$ & $67.36 \pm 0.87$ \\
\hline Control & $67.39 \pm 1.63$ & $66.74 \pm 1.29$ & $66.54 \pm 1.34$ \\
\hline $\mathrm{t}$ & 0.73 & 0.24 & 0.51 \\
\hline $\mathrm{p}$ & $>0.05$ & $>0.05$ & $>0.05$ \\
\hline
\end{tabular}


Analysis of the received data and normative [9] showed that indicators of 60 meters' run, latent period of motor response and run on the spot correspond to marl 2 points in all tested groups; tapping test corresponded to 4 points. Thus, level of quickness of $1^{\text {st }}-3^{\text {rd }}$ year girl students in average corresponds to mark "unsatisfactory".

Analysis of data after experiment (see fig.1) showed that all quickness indicators of experimental groups' girl students significantly and confidently improved $(\mathrm{p}<0.05-0.001)$.

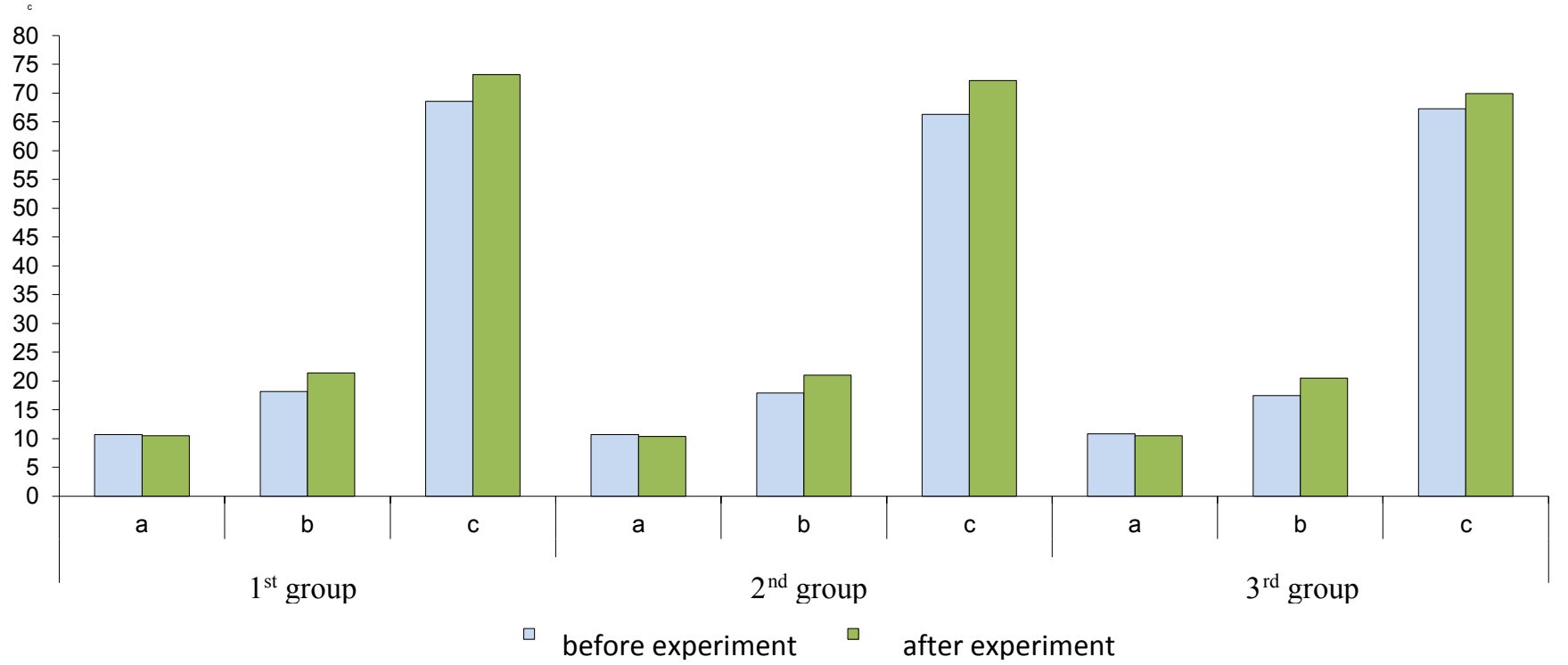

Fig 1. Indicators of quickness level in experimental groups before and after experiment: $\mathrm{a}-30$ meters' run (sec.), b - run on the spot (quantity of steps), c - tapping test (quantity of points).

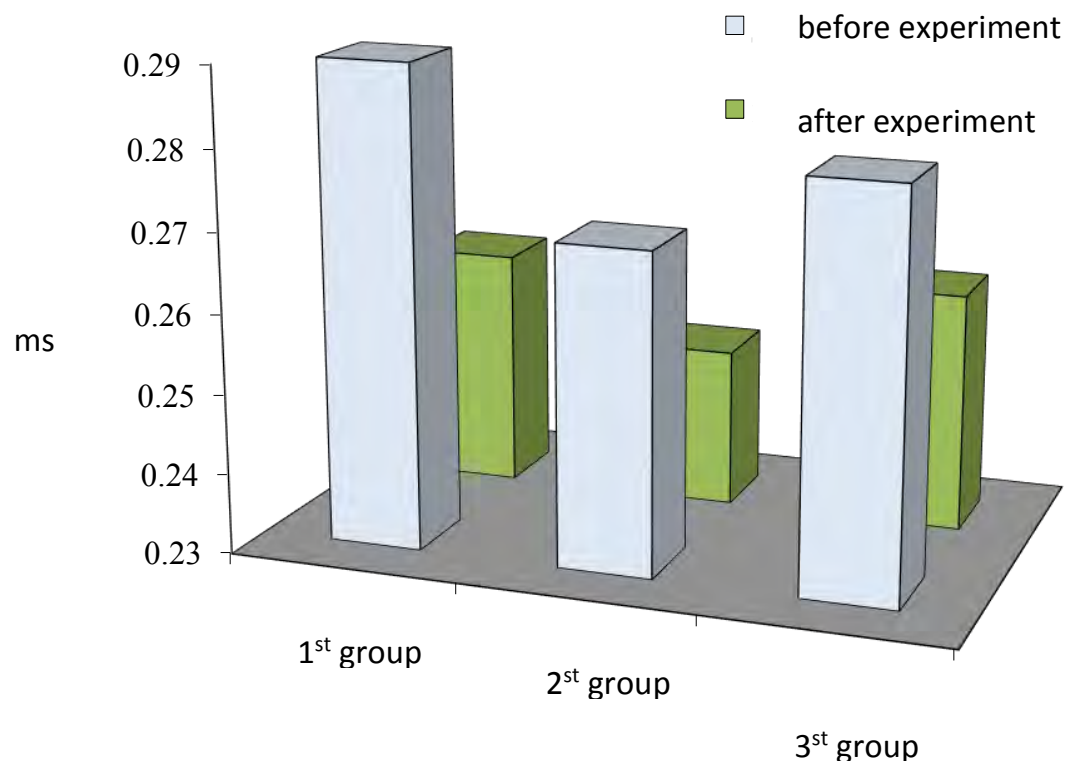

Fig. 2. Indicators of motor response in experimental groups before and after experiment

Analysis of experimental data showed that in 60 meters' run results of $1^{\text {st }}$ year girl students improved by $2.32 \%, 2^{\text {nd }}$ year girl students - by $2.33 \%, 3^{\text {rd }}-$ by $2.39 \%$; latent period of motor response improved by $10.34 \% ; 7.40 \%$; $7.14 \%$ accordingly; run on the spot - by $17.26 \% ; 17.32 \% ; 1.99 \%$ accordingly; tapping test - by $6.61 \% ; 8.90 \% ; 3.88 \%$ accordingly. Thus, substantial changes took place in frequency of legs' movements. The highest increment in quickness was observed in girls of 15 years old age. 
Analysis of control groups' data after experiment showed that their results also improved to some extent. But these changes were less significant than in experimental groups and were not confident ( $p>0.05)$. Results of tests were as follows: 60 meters' run of $1^{\text {st }}$ group girl students - improved by $1.48 \%, 2^{\text {nd }}$ group - by $2.05 \% ; 3^{\text {rd }}$ group - by $1.83 \%$ ); latent period of motor response - by $3.44 \% ; 3.70 \% ; 3.57 \%$ accordingly; run on the spot - by $6.24 \% ; 4.79 \% ; 4.52 \%$ accordingly; tapping test - by $2.83 \% ; 2.68 \% ; 4.68 \%$ accordingly.

Analysis of repeated data in age aspect revealed confident difference in indicators of tapping test between $1^{\text {st }}$ and $2^{\text {nd }}$ as well as between $2^{\text {nd }}$ and $3^{\text {rd }}$ experimental groups $(\mathrm{p}<0.05-0.001)$. The rest indicators do not significantly differ in comparison with initial data.

Comparison of repeated data of experimental groups with normative [9] showed increasing of results by 1 point of assessment scale in the following indicators: 60 meters' run and tapping test ( $1^{\text {st }}$ group's girl students) and latent period of motor response ( $1^{\text {st }}$ and $2^{\text {nd }}$ groups' girl students). As for the other indicators we observed their significant and confident improvement. But there were no changes by assessment scale. In our opinion it is explained by imperfectness of available assessment criteria.

Comparison of control groups' results showed analogous to experimental groups' character of changes by assessment scale in the following indicators: 60 meters' run and latent period of motor response.

Thus, application of specially selected cheer-leading exercises in process of girl students' physical education rendered positive influence on quickness level. The most substantial increment of results was noted in girls of 15 years old age.

Analysis of endurance data revealed absence of confident differences between indicators of control and experimental groups ( $p>0.05$ ) (see table 2). In age aspect we observed worsening of results with age (but statistically not confident $p>0.05$ ). Exclusion were the data of $1^{\text {st }}$ and $2^{\text {nd }}$ experimental groups' girl students, whose data were statistically different $(\mathrm{p}<0.001)$.

Table 2

Endurance indicators of experimental and control groups' girl students before experiment

\begin{tabular}{|c|c|c|c|}
\hline \multirow{3}{*}{ Groups } & I & II & III \\
\hline & \multicolumn{3}{|c|}{ Indicators $\bar{X} \pm \mathrm{m}$} \\
\hline & \multicolumn{3}{|c|}{2000 meters' run (min.) } \\
\hline$n$ & 75 & 108 & 95 \\
\hline Experimental & $16.69 \pm 0.12$ & $17.69 \pm 0.93$ & $17.41 \pm 0.14$ \\
\hline$n$ & 23 & 34 & 50 \\
\hline Control & $16.89 \pm 0.21$ & $16.70 \pm 0.17$ & $17.03 \pm 0.19$ \\
\hline $\mathrm{t}$ & 0.81 & 1.04 & 1.59 \\
\hline $\mathrm{p}$ & $>0.05$ & $>0.05$ & $>0.05$ \\
\hline
\end{tabular}

Comparison of 2000 meters' run results with normative (governmental physical education program) showed that in all tested groups they are significantly lower than standards and are far from reaching the lowest limit. That is why their mark was 0 points.

Analysis of results after application of cheer-leading (see fig.3) showed that endurance indicators in experimental groups significantly and confidently improved $(\mathrm{p}<0.001)$. For example, results of $1^{\text {st }}$ year girl students improved by $6.59 \%, 2^{\text {nd }}$ years - by $16.05 \%, 3^{\text {rd }}$ year - by $11.37 \%$. The highest increment in results of endurance training was observed in 16 years' old girls.

Analysis of analogous data of control groups' girl students showed confident improvement of results in $2^{\text {nd }}$ and $3^{\text {rd }}$ groups $(\mathrm{p}<0.05-0.01)$. For example, $1^{\text {st }}$ group girl students' results improved by $2.13 \% ; 2^{\text {nd }}$ group - by $2.93 \% ; 3^{\text {rd }}$ group - by $4.46 \%$. Percent increment of indicators in control groups was significantly lower than in experimental groups. It should be noted that in repeated results of control and experimental groups' girl students we observed significant and confident domination of experimental groups' results $(\mathrm{p}<0.001)$. 


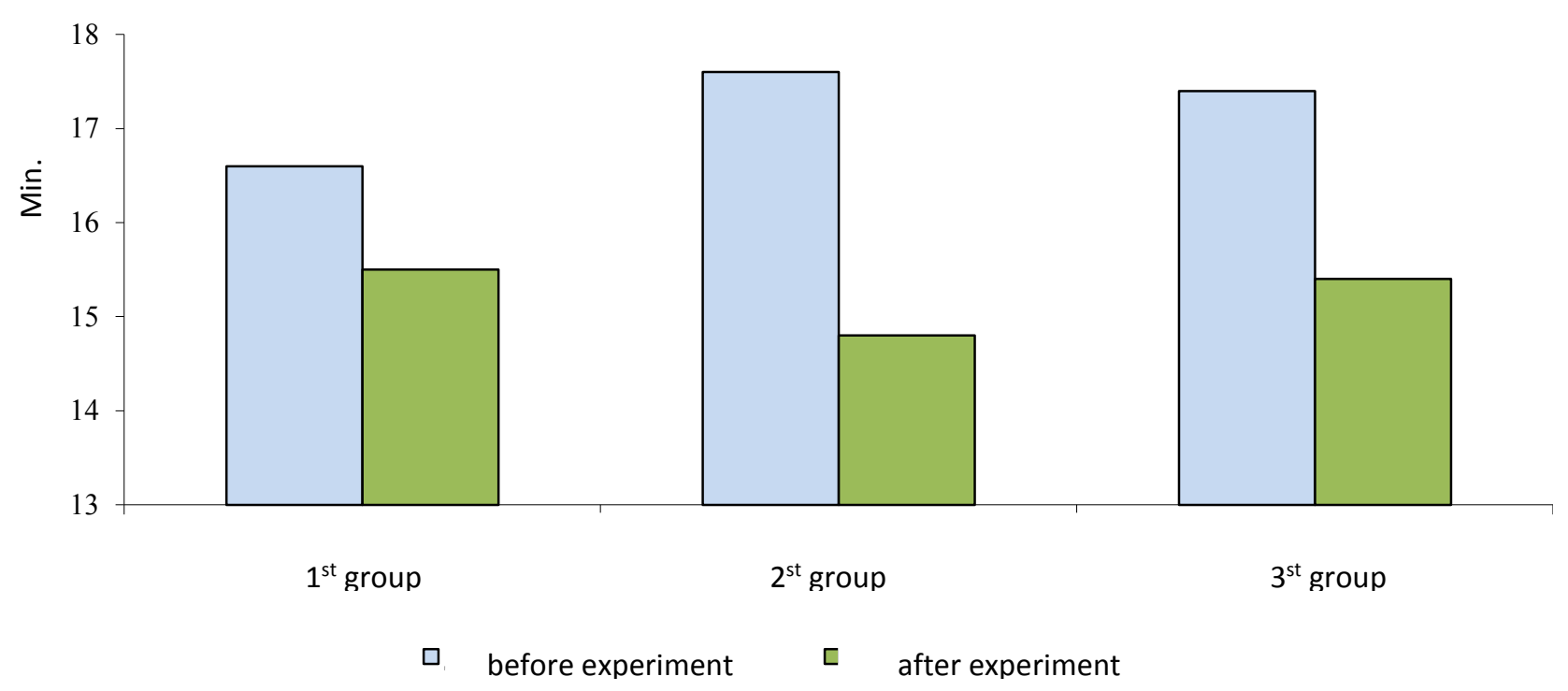

Fig.3. Indicators of endurance fitness of experimental groups' girl students before and after experiment

Analysis of repeated results in age aspect showed that character of differences changed significantly in experimental groups. For example, indicators of $1^{\text {st }}$ and $3^{\text {rd }}$ groups became much better and it was statistically confident $(\mathrm{p}<0.001)$. Analysis of analogous indicators of control groups did not reveal significant changes in comparison with initial data.

Comparison of repeated results of endurances testing with normative showed absence of changes by assessment scale: they equal to zero in all tested groups.

Thus, application of specially selected cheer-leading exercises in physical training of girl students positively influenced on endurance fitness. The highest increment of results was observed in 16 years' old girl students.

\section{Discussion}

Analysis of scientific-methodic literature showed that there is quite few works, devoted to cheer-leading implementation in physical education process in different educational establishments. Also quite a few works on problems of cheer-leading's influence on different aspect of training and formation of students' motor competence was found. In available works influence of cheer-leading exercises on pre school age children's physical condition was analyzed [12]; on physical health and motor qualities' condition of secondary schools pupils [2, 3, 13, 14]; on level of physical condition and physical workability of technical university girl students [11]; on power and coordination training of college students [7,21].

On the base of analysis and generalization of the conducted research's results we supplement the data of T.M. Bala [13] about positive influence of cheer-leading exercises on motor skills' training; expanded the data of N.V. Kryvoruchko, I.P. Masliak [7, 21] about influence of cheer-leading on students' motor abilities.

For the first time we determined: the most suitable for training by cheer-leading exercises forms of girl students' quickness; the most favorable age periods for training of quickness and endurance under influence of cheerleading exercises.

\section{Conclusions:} students.

1. As a result of initial testing we detected "low" level of quickness and endurance of pedagogic college girl

2. Application of cheer-leading exercises in physical education influenced positively on quickness and endurance of the tested contingent.

The further researches in this direction can be realized by means of determination of cheer-leading influence on physical abilities of higher educational establishments' girl students.

Acknowledgement

The researches have been fulfilled in compliance with topical plan of scientific-research works of Kharkov State Academy of Physical Culture for 2013 - 2015 by topic 3.5.29. "Theoretical and applied principles of organization of physical training, physical fitness and physical condition of different population strata monitoring”. 


\section{Conflict of interests}

The author declares that there is no conflict of interests.

\section{References:}

1. Andres A, Serbo E, Festriga S. Sportivno-orientovane fizichne vikhovannia studentiv [Sport oriented physical education of students]. Moloda sportivna nauka Ukraini, 2015;19:6-12. (in Ukrainian)

2. Bala TM, Maslyak IP. Zmina rivnia fizichnogo zdorov'ia shkoliariv 5-6-kh klasiv pid vplivom vprav cherlidinga [Change of physical health of 5-6 forms' pupils under influence of cheer-leading exercises]. Moloda sportivna nauka Ukraini, 2011;15:10-15. (in Ukrainian)

3. Bala TM, Maslyak IP. Zmina rivnia fizichnogo zdorov'ia shkoliariv 7-9-kh klasiv pid vplivom vprav cherlidinga [Change of physical health of 7-9 forms' pupils under influence of cheer-leading exercises]. Sportivnij visnik Pridniprov'ia, 2011;2:21-23. (in Ukrainian)

4. Bala TM, Maslyak IP. Chirliding u fizichnomu vikhovanni shkoliariv [Cheer-leading in physical education of schoolchildren], Kharkov; 2014 (in Ukrainian)

5. Zinchenko IA. Pobudova trenuval'nogo procesu sportsmeniv u cherlidingu na etapi specializovanoi bazovoi pidgotovki. Cand. Diss. [Building of sportsmen's training process in cheer-leading at stage of specialized basic training. Cand. Diss.], Kharkov; 2013 (in Ukrainian)

6. Kozina ZhL, Iermakov SS, Bazylyuk TA, Voloshina EV. Innovacionnye tekhnologii akvafitnesa igrovoj napravlennosti s primeneniem tekhnicheskikh ustrojstv $\mathrm{v}$ fizicheskom vospitanii studentok [Aqua-fitness innovative technologies of game orientation with application of technical devices in girl students' physical education]. Physical education of students, 2012;1:42-46. (in Ukrainian)

7. Krivoruchko N, Maslyak I. Dinamika pokaznikiv rozvitku koordinacijnikh zdibnostej studentiv VNZ pid vplivom vprav chirlidingu [Dynamic of coordination indicators of HEE students under influence of cheer-leading exercises]. Moloda sportivna nauka Ukraini, 2013; 7: 87-91. (in Ukrainian)

8. Malyar EI. Rozvitok profesijno vazhlivikh iakostej studentiv special'nosti «Opodatkuvannia» zasobami futbolu. Cand. Diss. [Training of professionally significant qualities of students (specialization "Taxation") by means of football. Cand. Diss.], Lviv; 2008 (in Ukrainian)

9. Romanenko VA. Diagnostika dvigatel'nykh sposobnostej [Diagnostic of motor abilities], Donetsk: Don NU; 2005 (in Ukrainian)

10. Terenteva NM, Mameshina MA, Maslyak IP. Teoriia ta metodika fizichnogo vikhovannia [Theory and methodic of physical education], Kharkov, KSAPC; 2010. (in Ukrainian)

11. Timofeeva OV. Chirliding v sisteme fizicheskogo vospitaniia studentok [Cheer-leading in system of girl students' physical education]. Teoriia i praktika fizicheskoj kul'tury, 2008;11:36-38. (in Russian)

12. Timofeeva TN,. Tatarinova OO, Vladimirova SM. Cherliding dlia doshkol'nikov [Cheer-leading for pre school age children]. Detskij sad: teoriia i praktika, 2011;10:68-75. (in Russian)

13. Bala T. Change in the level of strength and endurance development of 5-6 grades pupils under cheerleading exercises influence. Slobozhanskyi herald of science and sport , 2015; 3: 14-18.

14. Bala TM. The influence of cheerleading exercises on the schoolchildren's physical health of $5-9^{\text {th }}$ forms. Pedagogics, psychology, medical-biological problems of physical training and sports, 2012; 4: 12-16.

15. Belykh S. I. Health, physical education and physical development of students in historically and personally developing paradigm. Pedagogics, psychology, medical-biological problems of physical training and sports, 2013; 5: 7-12. http://dx.doi:10.6084/m9.figshare.707091

16. Carrier Justin, McKay Donna. Complete cheerleading. Human Kinetics: USA, 2006: 240.

17. Cieślicka M. Swimming lessons in improving the health of students. Pedagogics, psychology, medical-biological problems of physical training and sports, 2013; 12: 101-104. http://dx.doi:10.6084/m9.figshare.880636

18. Chappell Linda Rae. Coaching cheerleading successfully (second edition). Human Kinetics: In Canada, 2005: 206.

19. Grutsyak N. Volleyball in unsportsmanlike university : development trends. Slobozhanskyi herald of science and sport, 2015; № 2(46): 59-62.

20. Ilnitskaya AS, Kozina ZhL, Korobejnik VA, Ilnickiy SV, Cieślicka Mirosława, Stankiewicz Błażej, Pilewska Wiesława. The method of application of health systems Bodyflex and Pilates in physical education of 
students. Pedagogics, psychology, medical-biological problems of physical training and sports, 2014; 2 : 25-32. http://dx.doi:10.6084/m9.figshare.923510

21. Kryvoruchko NV, Masljak IP, Zhuravlyova IN. Impact on the display of power cheerleading ability of university students I-II levels of accreditation. Pedagogics, psychology, medical-biological problems of physical training and sports, 2013; 9: 38-42. http://dx.doi:10.6084/m9.figshare.749696.

22. Temchenko V. Influence of informational technologies on physical background of students engaged futsal in sportoriented physical education. Slobozhanskyi herald of science and sport, 2015; 3(47): 93-96.

23. Salatenko IA. Direction improvements professionally-applied physical preparation of students of economic specialties. Pedagogics, psychology, medical biological problems of physical training and sports, 2012; 11: 90-93. http://dx.doi:10.6084/ m9.figshare.97369.

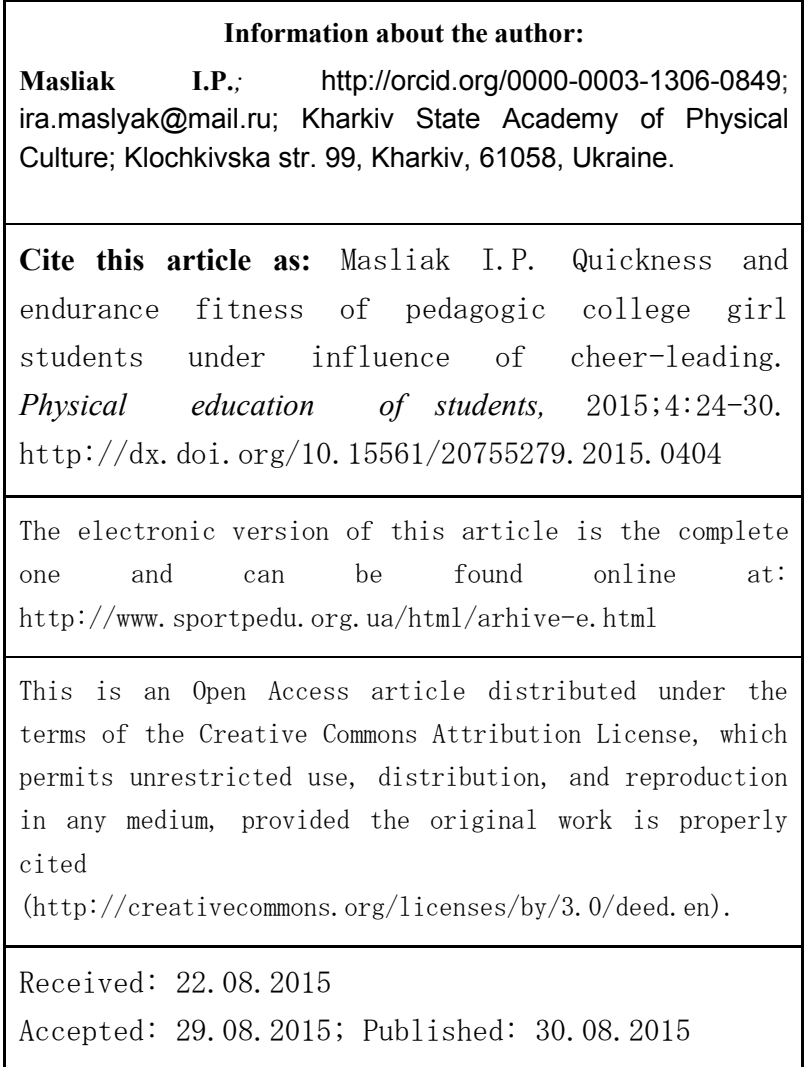




\title{
DEVELOPMENT OF GIRL-STUDENTS' PHYSICAL QUALITIES AT EXTRACURRICULAR CHEER-DANCE CLASSES (CHEER-DANCE SHOW)
}

Pyatnickaya D.V.

Kharkov Humanitarian Pedagogical Academy

\begin{abstract}
Purpose: to work out and substantiate methodic of cheer-dance means' usage in extracurricular trainings of girl students. Material: in experiment 450 girl-students of 17-20 years' age participated. Results: we generalized theoretical knowledge and practical experience in selection, content and organization of girl students' physical education. We presented the data of comparative analysis of girl students' physical condition and (sportswomen and not sportswomen). We noted significant interest to physical education, in which the offered methodic is used. It was found that demands in health strengthening can be formed by means of dance kinds of cheer-leading (cheer-dance and cheer-dance show). Conclusions: We have found prospects of girl students' physical education perfection. It permits to work out different variants of realization of educational health related strategy.
\end{abstract}

Key words: girl students, higher educational establishments, fitness, cheer-dance, cheer-dance show, physical qualities, health.

\section{Introduction}

Recent time in Ukraine there have been being observed steady tendency for reduction of health of population and students in particular. It is also paid attention to in governmental document, regulating physical education in higher educational establishments (HEE). It is studied by specialists in physical culture and sports.

For example, in researches $[1,7,9,11,18,30,34]$ it was established that in period of studying in higher educational establishments quantity of special health group students increases up to $5.3 \%$ in the first year and up to $14.4 \%$ in the forth year. Accordingly, we can observe reduction of quantity of main group students: from $84.0 \%$ to $70.2 \%$.

Besides, researches of other authors [11-13, 19-21, 27, 38-44] witness about low level of physical conditions, physical fitness and workability of students. Authors note insufficient level of solution of main physical education tasks. As a result (after graduation) most of graduates are not physically able to fulfill professional duties with proper quality and intensity. So working potential of youth reduces, though social and economical welfare of our country depends on it.

In this connection, one of the most important tasks of physical education in higher educational establishment is strengthening of health, rising of physical fitness and physical condition of students.

A number of authors $[6,10,19,20,25,26,28]$ note decrease of motivation and interest to physical education classes. Results of these researches point at monotonous character of training material, insufficient effectiveness of existing methodic and forms of physical culture trainings. That is why the problem of upgrading of HEE physical education by implementation of innovative approaches to organization of training process, considering students' motivation, is rather important and urgent. Besides new, modern kinds of motor functioning, which would encourage students for physical exercises, require their implementation. That is why urgency of this problem is evident and requires explanation and analysis.

Purpose, tasks of the work, material and methods

The purpose of the research: is to work out and substantiate methodic of cheer-dance means' usage in extracurricular trainings of $1^{\text {st }}-2^{\text {nd }}$ year girl students.

The tasks of the research:

1. To generalize theoretical knowledge and practical experience in selection, content and organization of higher educational girl students' physical education in process of extracurricular classes.

2. To determine girl students' physical condition and physical fitness.

3. To carry out comparative analysis of girl students' physical condition and fitness: group of not sportswomen and group of cheer-dancers (cheer-leading).

() Pyatnickaya D.V., 2015

http://dx.doi.org/10.15561/20755279.2015.0305 
4. To work out and experimentally prove methodic of application of cheer-dance means in extracurricular trainings of girl students.

5. To work out practical recommendations for physical culture teachers on implementation of the offered cheer-dance methodic in physical education process.

The object of the research: physical education of higher educational establishments' girl students in process of extracurricular trainings.

The subject of the researches: methodic of cheer-dance means' application in extracurricular trainings of $1^{\text {st }}-2^{\text {nd }}$ year girl students of higher educational establishments.

The methods of the research: analysis and generalization of literature data on this topic; generalization of advanced experience of specialists in physical education and coaches with the help of talks and questioning; pedagogic observations over competition and training functioning; pedagogic testing (determination of motor skills' level), functional testing of cardio-vascular and respiratory systems; pedagogic experiment; methods of mathematical statistic.

The contingent of the tested: first and second year girl students of Municipal establishment "Kharkov Humanitarian Pedagogical Academy" of Kharkov regional council. In experiment 450 girl students of 17-20 years' age participated.

We formed experimental and control groups. Each group consisted of 27 girl students. Distribution of girl students into groups was fulfilled by results of questioning, devoted to choosing of motor functioning at physical education classes. That is why trainings of experimental group included dance kinds of cheer-leading: cheer-dance and cheer-dance show $[22,34]$. Control group was trained by traditional academic program for HEEs of Ukraine of III-IV accreditation. The research was conducted in stage-by-stage way.

At first stage we realized the following: pedagogic testing; initial testing of physical condition and physical fitness; analysis and generalization of scientific-methodic literature; determination of purpose, tasks, object and subject of the researches; selection of methods of the researches; working out of experimental methodic of training. Experimental methodic of trainings was oriented on reduction of body mass, normalization of metabolism, giving up of harmful habits, improvement of physical condition and general state, on propaganda of healthy life style (HLS) and motivation for physical exercises' practicing. Content of cheer-dance trainings included dance block. This block was built on the base of cheer-leading's basic elements: pirouettes, splits, waving, cheer-jumps, leaps. There were no elements of acrobatics, supports of partner, pyramids. That is why this methodic was quite accessible for girl students. Cheer-dance exercises included movements and musical fragments of different dance styles (jazz, funk, pop, rap, lyrical dance and so on). That is why this kind of cheerleading facilitates not only physical development of girl students' motor skills but also their aesthetic education.

At second stage we conducted pedagogic experiment. It implied that application of cheer-dance means in extracurricular trainings stimulated interest to physical exercises. They were oriented on formation and strengthening of health, perfection of physical condition and fitness.

At third stage we processed the received results and fulfilled comparative analysis of them. It permitted to determine effectiveness of methodic of cheer-dance means' application in extra curricular trainings of higher educational establishments' girl students.

\section{Results of the research}

A number of authors dealt with perfection of physical education in HEEs of different profiles at the account of implementation of training material's optimal content, new forms and means. For example Barybina L.M., Semashko S.A., Kriventsova H.V. [5] worked out system of aerobic trainings with application of individual approach. Mishchenko V.S., Kuehne T., Vinogradov V.E., Melnik L.J., Niewiadomska A. [24] implemented 8- weeks' program of physical exercises, mainly of power character in combination with vibration impact of rotational type. The purpose of such researches is increasing of girl students' power potentials. Zaharova L.V., Lyulina N.V. [15] worked out aerobic experimental methodic with usage of imitation exercises of different kinds of sports. Uskov S.V. [31] regarded problems of preservation and strengthening of schoolchildren's and students' psychic health with the help of martial arts' trainings on example of karate-do. Yasko G.V., Kashuba E.V. [17] implemented Hatha yoga methods in students' learning process. Balamutova N.M., Babadganjan V.V. [4] applied hydro-pedagogic and hydro-kinesio-therapy as mean of students' suffering 
form scoliosis rehabilitation. Kozina Z.L. et al. [19] implemented game-oriented aqua-fitness with application of special technical devices. Voronov M.P., Stolyarenko O.M. [8] studied health related influence of gymnastic exercises with usage of modern computer technologies, oriented on formation of students' correct carriage. Bala T.M. [2, 3] researches influence of cheer-leading exercises on secondary schoolchildren's physical health and motor fitness. Loutsenko L.S. et al. [23] regarded construction of sportsmen's training process in cheer-leading at stage of specialized basic training. Ilnitskaya A.S. et al. [16] studied methodic of physical exercises' training on the base of body-flex and pilates. Fomenko E.V. [32] used innovative methodic of application of nontraditional kinds of gymnastic in extracurricular girl students' trainings and so on.

However, we have not found works, devoted to methodic of cheer-dance trainings and their influence on HEE students' physical condition and physical fitness.

With it, it should be noted that cheer-leading is modern, progressive, spectacular kind of motor functioning. It is becoming still more popular in our country.

This term resulted from English cheer-leading, where "cheer" - call and "lead" - means guide. One of its kinds is cheer-dance (cheer-dance show). It means call for dance (presenting of plot in dance). This is the simplest kind of cheer-leading because it does not require special equipment and large site for trainings. It excites by its movements and attracts modern youth by its show character. It can be practiced both by girls (cheer dance) and by boys (cheer-dance show).

In our opinion usage of specially selected cheer-dance exercises in physical education process will positively reflect on indicators of students' physical condition and physical fitness, increase their interest to physical trainings. That is why there is an urgent demand in working out of methodic of cheer-dance means' usage in girl students' physical education.

The largest reserves of application of such means belong to effective organization of health related physical culture functioning of girl students, especially in extracurricular classes [21, 29, 33]. However, physical education trainings with usage of modern technologies (in particular cheer-dance) differ from traditional. These trainings require provisioning of students with the newest modern information about health; lead to increased organism's energy losses. Results of the researches determine dominating preferences of students to training of different kinds of physical exercises.

Practical significance of our research is in working out of methodic of cheer-dance movements' usage, their rational application in girl students' extracurricular trainings. It permits to improve their physical condition, physical fitness and interest to physical culture trainings. Besides, the received materials can be used for formation and preparation of students' cheer-dance (cheer-dance show) teams for competitions of different levels.

\section{Discussion}

Results of testing of experimental group's girl students witness about their higher indicators in comparison with control group (see table 1).

Table 1

Confidence of indicators of first and second year girl students of experimental group

\begin{tabular}{|l|l|l|l|l|l|}
\hline № & \multicolumn{1}{|c|}{$\begin{array}{c}\text { Indicators } \\
\text { In=27) }\end{array}$} & $\begin{array}{c}\text { 19-20 years' age } \\
(\mathbf{n = 2 7})\end{array}$ & \multicolumn{1}{|c|}{ p } & t \\
\hline \multicolumn{6}{|c|}{ Indicators of physical condition } \\
\hline 1 & Mass, kg & $56.4 \pm 2.6$ & $60.7 \pm 2.9$ & $<0.05$ & 2.13 \\
2 & Vital capacity of lungs (VCL), cm ${ }^{3}$ & $2950 \pm 96.3$ & $2770 \pm 101.7$ & $<0.05$ & 1.28 \\
3 & Heart beats' rate (HBR) b.p.m. & $69.1 \pm 1.46$ & $69.6 \pm 1.84$ & $<0.05$ & 0.25 \\
\hline \multicolumn{7}{|c|}{ Physical fitness } \\
\hline 1 & Quantity of jumps per 20 sec, times & $61.4 \pm 2.81$ & $59.2 \pm 3.12$ & $<0.05$ & 0.3 \\
3 & Flexibility, cm & $13.32 \pm 1.84$ & $9.97 \pm 2.03$ & $<0.05$ & 1.22 \\
\hline
\end{tabular}


Implementation of new kind of motor functioning (cheer-dance) resulted in girl students' higher load on cardio-vascular and respiratory systems. In experimental group's students pulse insignificantly increased. In control group HBR was much higher. Speed of motor response was assessed with test for speed of seizing of falling stick with stronger hand. The test's results showed that quality of this test's fulfillment reduced quicker in experimental group (19-20 years' age). In first group this indicator was $9.86 \pm 0.86 \mathrm{sec}$. In older group it was $13.2 \pm 1.02 \mathrm{sec} .(\mathrm{t}=2.51)$. Change of flexibility was assessed by forward torso bent from sitting position. Speedpower endurance was measured by maximal quantity of jumps from the spot during $20 \mathrm{sec}$. In older group this indicator was less a little (see table 1).

Thus, comparative analysis of experimental group girl students' physical condition and physical fitness showed significant changes in their organisms in comparison with girl students of control group.

In our work we supplement and specified results of researches of V.P. et al. [14, 45], Iermakov S.S. et al. [11], Kozina Zh.L. et al. [19], Fomenko E.V. [32], Adashevskiy V.M. et al. [35], Buultjens M. и Robinson P. [36], Highstreet V.D. [37] et al. about advantages of physical education trainings with application of modern technologies in comparison with traditional trainings. Such trainings are accompanied by higher interest of students. They give students information about health and means of increasing of organism's energy consumption.

The received results showed girl students' dominating preferences of different kinds of physical exercises. Besides, we supplemented data base about specificities of cheer-dance exercises' training.

In our research conception of Krucevich T.I. [21] about importance of development and application of innovative technologies in students' physical education is further developed as well as conceptions of Kozina Z.L. and Iermakov S.S. [20] about purposefulness of working out and application of non-traditional systems in students' physical education.

\section{Conclusions:}

1. Implementation of substantiated methodic of cheer-dance trainings permits for girl students to significantly improve physical fitness, physical conditions and functional state of their organisms.

2. The worked out practical recommendations can be used in educational process of physical culture institutions, physical education faculties of pedagogic universities, higher physical culture establishments especially in studying of disciplines: theory and methodic of aerobic training, sportpedagogic perfection, and as an independent component. Besides they can be used as a supplement to existing educational systems, working out of learning and methodic manuals.

It is recommended to direct further researches to finding of changes in girl students' physical condition after application of the offered cheer-dance methodic. Besides, they shall be pointed at studying of comparative characteristics of physical condition and physical fitness of $3^{\text {rd }}$ and $4^{\text {th }}$ year girl students, practicing cheer-dance.

\section{Acknowledgement}

The researches have been conducted in compliance with "Combined plan of scientific-research works in sphere of physical culture and sports for 2011-2015" by topic 2.4 "Theoretical-methodic principles of individualization in physical education and sports" (state registration number 0112U002001). The researches were fulfilled in compliance with scientific-research works at the account of governmental budget of Ministry of education and science of Ukraine for 2014-2015 "Theoretical-methodic principles of application of informational, pedagogic and medical-biological technologies for formation of healthy life style" (state registration number 0113U002003) and "Theoretical-methodic provisioning of formation of personality's healthy life style in conditions of educational establishment in context of European integration" (state registration number $0114 \mathrm{U} 001781$ ).

\section{Conflict of interests}

The author declares that there is no conflict of interests.

\section{References}

1. Arefiev VG. Modeling of differentiated physical fitness in school children. Pedagogics, psychology, medical-biological problems of physical training and sports, 2014;1:3-8. http://dx.doi.org/10.6084/m9.figshare.894383 
2. Bala TM. The influence of cheerleading exercises on the schoolchildren's physical health of 5-9th forms. Pedagogics, psychology, medical-biological problems of physical training and sports, 2012;4:12 - 16.

3. Bala TM. Kompleksna ocinka vplivu vprav cherlidingu na fizichne zdorov'ia ta rukhovu pidgotovlenist' shkoliariv serednikh klasiv. Cand. Diss. [Complex assessment of cheer-leadin exercises' influence on physical health and motor fitness of secondary schoolchildren. Cand. Diss.]. Kharkov, 2013.

4. Balamutova NM, Babadganjan VV. Hydro aerobics as means for physical state improvement of female students. Pedagogics, psychology, medical-biological problems of physical training and sports, 2013;3:3-6. http://dx.doi.org/10.6084/m9.figshare.644731

5. Barybina LM, Semashko SA, Kriventsova HV. Features of organization of sport mass work at the technical higher institution. Physical Education of Students, 2011;1:18-22.

6. Bubka SN. The role of Alexey Butovsky in the development of physical education, sport and Olympic Movement. Pedagogics, psychology, medical-biological problems of physical training and sports, 2012;9:58.

7. Vas'kov YV. Acmeological approach to physical education of students of secondary schools in the aspect of personality-oriented training. Pedagogics, psychology, medical-biological problems of physical training and sports, 2015;3:3-9. http://dx.doi.org/10.15561/18189172.2015.0301

8. Voronov MP, Stolyarenko OM. Influence of physical exercises on students with violation of organs of sight. Physical education of students, 2010;6:13-15.

9. Gryban GP. The evaluation of the efficiency of introducing the model of the methodical system of physical education of agrarian students. Pedagogics, psychology, medical-biological problems of physical training and sports, 2012;11:27-30. http://dx.doi.org/10.6084/m9.figshare.97350

10. Dovhanyk MS, Chychkan OA, Sirenko RR. Parameters of alpha - rhythm in the students who practise curative running. Pedagogics, psychology, medical-biological problems of physical training and sports, 2012;5:59-62.

11. Iermakov SS, Apanasenko GL, Bondarenko TV, Prasol SD. Physical culture as the main tool of health's culture. Pedagogics, psychology, medical-biological problems of physical training and sports, 2010;11:31 33 .

12. Iermakova TS. Forming a health culture of future teachers in Polish educational establishments. Physical Education of Students, 2014;5:14-19. http://dx.doi.org/10.15561/20755279.2014.0503

13. Iermakova TS. Education of children in Polish family in a context of forming health culture. Pedagogics, psychology, medical-biological problems of physical training and sports, 2014;11:17-22. http://dx.doi.org/10.15561/18189172.2014.1104

14. Zajcev VP, Iermakov SS., Prusik Kr. Physical recreation in structure of students' active rest. Physical education of students, 2011;1:68-77.

15. Zaharova LV, Lyulina NV. Basis of integrated approach to sports and recreational activities of students of special medical groups. Physical Education of Students, 2014;1:17-21. http://dx.doi.org/10.6084/m9.figshare.903688

16. Ilnitskaya AS, Kozina ZL, Lakhno EG, Ilnitskaya LV, Cieślicka Mirosława, Stankiewicz Błaźej, Pilewska Wiesława. Students' attitude to the possibility of applying modern information and communication technologies in the educational process in physical education. Physical Education of Students, 2014;2:18-24. http://dx.doi.org/10.6084/m9.figshare.906369

17. Yasko GV, Kashuba EV. Innovation sports and health areas in universities supporting basis orientation. Physical education of students, 2011;3:116-118.

18. Kozhevnikova LK. Professional-applied pedagogical teaching of junior school future teachers to working activity. Physical Education of Students, 2012;3:49-52.

19. Kozina ZL, Iermakov SS, Bazilyuk TA, Voloshina E. Innovative technologies of aquafitness of playing orientation with the use of technical devices in physical education of students. Physical education of students, 2012;1:42-46. 
20. Kozina ZL, Iermakov SS. Analysis of students' nervous system's typological properties, in aspect of response to extreme situation, with the help of multi-dimensional analysis. Physical Education of Students, 2015;3:10-19. http://dx.doi.org/10.15561/20755279.2015.0302

21. Krucevich TI, Bezverkhnia GV. Rekreaciia u fizichnij kul'turi riznikh grup naselennia [Recreation in physical education of different population groups], Kiev: Olympic Literature; 2010. (in Ukrainian)

22. Lisickaia TS. Aerobika na vse vkusy [Aerobics to all tastes]. Moscow: Education, 1994. (in Russian)

23. Loutsenko LS, Zinchenko IA, Luchko OR, Shepelenko TV. Construction of annual cycle of preparation of sportsmen, specialized in cheerleading. Physical education of students, 2011;6:62-66.

24. Mishchenko VS, Kuehne T, Vinogradov VE, Melnik LJ, Niewiadomska A. The effects of health-related physical training combined with whole body vibration (vibration platform) on strength capacities of young females. Physical Education of Students, 2012;1:75-83.

25. Moskalenko NV, Kovtun AA. Influence of physical culture and sport on the psychophysiological state of students. Physical Education of Students, 2012;3:83-86.

26. Nosko MO, Iermakov SS, Garkusha SV. Theoretical and methodological aspects of strengthening physical health of pupils and students. Visnik Chernigivs'kogo nacional'nogo pedagogichnogo universitetu, 2010;76:243-247. (in Ukrainian)

27. Popichev M.I. Complex diagnostics and estimation of health of students level. Physical Education of Students, 2011;3:71-76.

28. Roters TT. Physical improvement of students during interactive physical and aesthetic education. Physical Education of Students, 2013;4:72-76. http://dx.doi.org/10.6084/m9.figshare.663624

29. Serhiyenko LP, Lyshevska VM. Soles dermatoglyphics in the prognosis of sports endowment: differences of soles dermatoglyphics in sportsmen of different sport kinds. Pedagogics, psychology, medical-biological problems of physical training and sports, 2013;3:57-61. http://dx.doi.org/10.6084/m9.figshare.644738

30. Timoshenko OV. Simulation technology achievement of students in physical education classes. Physical Education of Students, 2010;3:102 - 105.

31. Uskov SV. Formation of stress students in the process of notions of martial arts in high school. Physical Education of Students, 2013;5:88-92. http://dx.doi.org/10.6084/m9.figshare.771216

32. Fomenko EV. Practical recommendations for the implementation of health technologies to enhance physical fitness of students in extracurricular classes during non-traditional gymnastics. Pedagogics, psychology, medical-biological problems of physical training and sports, 2014;7:31-36. http://dx.doi.org/10.6084/m9.figshare.1015385

33. Furman YM, Salnikova SV. Improvement of aerobic energy supply processes in 37-49 yrs old women by means of complex aqua-fitness trainings' and methodic of endogenous - hypoxic breathing's application. Pedagogics, psychology, medical-biological problems of physical training and sports, 2015;7:59-63. http://dx.doi.org/10.15561/18189172.2015.0708

34. Shkola OM. Teoriia ta metodika navchannia [Theory and methodic of training]. Kharkov: FOP Brovin O.V., 2014. (in Ukrainian)

35. Adashevskiy VM, Iermakov SS, Firsova IuIu. Physical mathematical modelling of difficult elements of acrobatic rock-and-roll. Physical Education of Students, 2013, vol.3, pp. 3-10. http://dx.doi.org/10.6084/m9.figshare.662463

36. Buultjens M, Robinson P. Enhancing aspects of the higher education student experience. Journal of Higher Education Policy and Management. 2011;33(4):337-346. http://dx.doi.org/10.1080/136008 0X.2011.585708.

37. Highstreet VD. Aerobics for All Ages: A Broadband Approach to a Diverse University Population. Journal of American College Health. 1983;32(3):125-127. http://dx.doi.org/10.1080/07448481.1983.9936156.

38. Iermakov SS. Bio-mechanical models of strike movements in context of perfection of sportsmen technical fitness. Teoria ta metodika fizicnogo vihovanna, 2010;4:11-18. (in Ukrainian)

39. Iermakov SS, Kriventsova IV, Minenok AA. Peculiarities of physical training of special health group students in pedagogic HEE. Visnik Chernigivs'kogo derzhavnogo pedagogichnogo universitetu, 2013;107(2):193-197. (in Russian) 
40. Ivashchenko OV, Khudolii OM, Yermakova TS, Pilewska W, Muszkieta R, Stankiewicz B. Simulation as

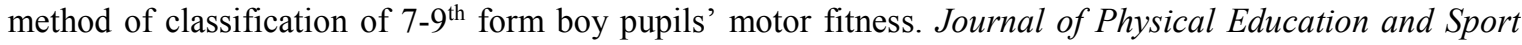
(JPES), 2015;15(1):142-147. http://dx.doi.org/10.7752/jpes.2015.01023

41. Ivashchenko OV, Yermakova TS, Cieslicka M, Zukowska H. Discriminant analysis in classification of motor fitness of 9-11 forms' juniors. Journal of Physical Education and Sport (JPES). 2015;15(2):238-244. http://dx.doi.org/10.7752/jpes.2015.02037

42. Khudolii OM, Iermakov SS, Prusik K. Classification of motor fitness of 7-9 years old boys. Journal of Physical Education and Sport (JPES), 2015;15(2):245-253. http://dx.doi.org/10.7752/jpes.2015.02038

43. Klimenchenko VG, Kriventsova IV, Gorban' IIu, Makhonin IM. Features of the procedure of joint exercises for physical education with students of basic and special medical groups. Pedagogics, psychology, medicalbiological problems of physical training and sports, 2014;4:18-21. http://dx.doi.org/10.6084/m9.figshare.950951

44. Prusik Krzysztof, Prusik Katarzyna, Kozina ZhL, Iermakov SS. Features of physical development, physical preparedness and functional state of boys and girls - students of Polish higher educational establishments. Physical Education of Students, 2013;1:54-61. http://dx.doi.org/10.6084/m9.figshare.96415

45. Zaycev VP, Iermakov SS, Manycharyan SV, Fedyay IA. Recreation as a scientific discipline and its historical aspects. Pedagogics, psychology, medical-biological problems of physical training and sports, 2012;12:46-52. http://dx.doi.org/10.6084/m9.figshare.105444 


\section{Information about the author:}

Pyatnickaya D.V.; http://orcid.org/0000-0001-9972-8402; matushkadariya@mail.ru; Kharkov Humanitarian Pedagogical Academy; Sh. Rustaveli alley 7, Kharkov, 61000, Ukraine.

Cite this article as: Pyatnickaya D. V. Development of girl-students' physical qualities at extracurricular cheer-dance classes (cheer-dance show). Physical education of students, 2015;4:31-38. http://dx. doi. org/10. 15561/20755279. 2015. 0405

The electronic version of this article is the complete one and can be found online at: http://www. sportpedu. org. ua/html/arhive-e. html

This is an Open Access article distributed under the terms of the Creative Commons Attribution License, which permits unrestricted use, distribution, and reproduction in any medium, provided the original work is properly cited

(http://creativecommons. org/1icenses/by/3.0/deed. en).

Received: 16.08.2015

Accepted: 16.08.2015; Published: 30.08.2015 


\title{
MECHANISMS OF ADAPTATION TO INTENSIVE LOADS OF 400 METERS' HURDLES RUNNERS AT STAGE OF INITIAL BASIC TRAINING
}

Rovniy A.S., Lastochkin V.M.

Kharkov State Academy of Physical Culture

Sumy State A.S.Makarenko Pedagogical University

\begin{abstract}
Purpose: is study of adaptation mechanisms of 400 meter' hurdles-runners to intensive physical loads. Material: in the research 13 - 400 meters' hurdles-runners and 13 - 400 meters' runners participated. Results: it was found that physiological cost of sportsmen's special workability has fragmentary character. We presented results of physiological and bio-chemical adaptation mechanisms to dozed work. The received results have no confident distinctions and can not objectively characterize mechanisms of sportsmen's special workability. We did not detect definite differences in indicators of mechanisms, ensuring sportsmen's special workability under dozed loads. We found, that level of anaerobic glycolysis is an objective criterion of 400 meter' hurdles-runners' special workability. It was shown that for determination of functional potentials for such kind of functioning it is necessary to apply special loads. Conclusions: the received results deepen information about mechanisms of adaptation to specific competition functioning. Correct approaches to processing and analysis of the research's results permit to more specifically determine sportsmen's functional potentials in different kinds of competition functioning.
\end{abstract}

Key words: adaptation, anaerobic glycolysis, lactate, specific, non-specific, distance.

\section{Introduction}

The problem of adaptation to physical loads is one of the main in system of training in different kinds of sports. Alongside with specific character of adaptation in every kind of sports, there are some general principles and laws [3, 18]. Physical loads' duration and intensity are important factors of sportsmen's adaptation to them as well as individual sensitivity to anaerobic hypoxic impacts [3, 19].

Sport achievements in 400 meters hurdles are not sufficient in Ukraine. That is why registration of adaptation responses in process of sportsmen's training is one of main factors of management of training process $[1,4]$.

Analysis of literature data witnesses that to large extent aspects of sportsmen's organism's adaptation to physical loads in running smooth distances have been studied rather in detail [12, 14, 20]. Comparative characteristic of adaptation responses of 400 meters hurdles-runners under different training loads will facilitate optimization of training process. Just this fact preconditioned the topicality of the given research.

Purpose, tasks of the work, material and methods of the research

The purpose of our work was studying of 400 meter' hurdles-runners' mechanisms of adaptation to intensive physical loads.

\section{The tasks:}

- To determine optimal scopes of training loads for 400 meters' hurdles-runners on the base of physiological and bio-chemical reactions;

- To determine the most adequate combination of load and rest in process of training of 400 meters' hurdles-runners;

Material and methods of the research: in the research 13 - 400 meters' hurdles-runners and $13-400$ meters' runners participated. Sportsmen fulfilled work on treadmill with constant angle of elevation of $3^{\circ}$. The sportsmen endured load with step-by-step increasing of intensity: from 2.5 m.p.sec. to 0.5 m.p.sec. (transition every 2 minutes and further - up to the end). Determination of maximal oxygen consumption (MOC) was carried out by automatic gas analyzer "Backman" with computer data registration. Before and after loads the tested underwent blood sampling from finger for determination of acid-base balance $(\mathrm{pH})$ and concentration of lactate (HL).

(c) Rovniy A.S., Lastochkin V.M., 2015

http://dx.doi.org/10.15561/20755279.2015.0306 


\section{Results of the research}

Analysis of mean group values showed that during work on treadmill ventilation of sportsmen's lungs increases sharply in comparison with rest state (more than 10 times) (see table 1). Increase of lungs' ventilation results from increase of oxygen consumption during work. It is witnessed by coefficient of correlation: between MOC and lung ventilation $(\mathrm{r}=0.65)$; MOC and carbon dioxide $\left(\mathrm{CO}_{2}\right)$ accumulation $(\mathrm{r}=0.54)$.

Table 1

Indicators of maximal physiological and bio-chemical reactions of 400 meters hurdles-runners before and after work on treadmill

\begin{tabular}{|c|c|}
\hline Before load & After load \\
\hline Indicators $(\mathrm{M} \pm \mathrm{m})$ & Indicators $(\mathrm{M} \pm \mathrm{m})$ \\
\hline HBR $62.3 \pm 0.47$ & HBR $198.9 \pm 9.0$ \\
\hline $\mathrm{PCO}_{2}(\mathrm{~mm}) 39.43 \pm 0.58$ & $\mathrm{PCO}_{2}(\mathrm{~mm}) 42.35 \pm 1.37$ \\
\hline $\mathrm{PO}_{2}$ (mm.merc.col) $70.53 \pm 1.98$ & $\mathrm{PO}_{2}$ (mm.merc.col) $80.76 \pm 1.38$ \\
\hline $\mathrm{pH}$ (conv.un.) $7.38 \pm 0.02$ & $\mathrm{pH}$ (conv.un.) $7.12 \pm 0.03$ \\
\hline HL (mol p.l) $2.7 \pm 0.13$ & HL (mol p.l) $11.6 \pm 0.84$ \\
\hline LV (1.p.min.) $12.78 \pm 0.31$ & LV (1.p.min) $134.4 \pm 6.87$ \\
\hline
\end{tabular}

Notes: * Work up to the end lasted in average 8-14 min.; * MOC with such work- 68.77 \pm 1.64 ml.p.kg.p.min. $\mathrm{HBR}$ - heart beats rate; LV - lung ventilation; $\mathrm{PCO}_{2}$ - partial pressure of carbon dioxide; $\mathrm{PO}_{2}$ - partial pressure of oxygen; $\mathrm{pH}$ - homeostasis (acid-base balance); HL - lactate.

We determined the state of homeostasis and differences in it as well as differences in character of HL removal from blood in rest period. In some sportsmen lactate quickly diffused from muscles to blood and was quickly removed from blood. But there were cases when lactated diffused only by $10^{\text {th }}$ minute of rest.

Quantity of lactate in blood by $20^{\text {th }}$ minute of rest is confidently connected with maximal $\mathrm{pH}$ level $(\mathrm{r}=0.540)$, reserves of buffer bases $(\mathrm{r}=0.580)$, value of oxygen $\mathrm{O}_{2}$ supply $(\mathrm{r}=0.590)$.

Having determined general regularities of physiological and bio-chemical parameters' dynamic under load on treadmill we made attempt to compare adaptation reserves of 400 meters' runners and 400 meters' hurdles-runners (see table 2).

Table 2

Comparative characteristic of physiological and biochemical indicators, taken in process of work on treadmill, of 400 meters runners and 400 meters' hurdles-runners.

\begin{tabular}{|c|c|c|c|c|c|c|c|c|c|c|c|c|}
\hline \multicolumn{6}{|c|}{ In rest } & \multicolumn{7}{|c|}{ After load } \\
\hline HBR & LV & HL & $\mathrm{pH}$ & $\mathrm{PCO}_{2}$ & $\mathrm{PO}_{2}$ & HBR & LV & MOC & $\mathrm{pH}$ & HL & $\mathrm{PCO}_{2}$ & $\mathrm{PO}_{2}$ \\
\hline \multicolumn{13}{|c|}{400 meters' hurdles-runners } \\
\hline 61.0 & 12.5 & 1.44 & 7.37 & 39.7 & 69.8 & 187.8 & 140.7 & 69.2 & 7.11 & 13.36 & 42.24 & 73.7 \\
\hline \multicolumn{13}{|c|}{400 meters' runners } \\
\hline 62.4 & 11.56 & 1.74 & 7.39 & 39.8 & 69.8 & 205.4 & 132.4 & 67.8 & 7.13 & 13.14 & 46.22 & 84.54 \\
\hline
\end{tabular}


Analysis of results witnesses that differences between indicators of functional reactions and physical workability of both groups' sportsmen in laboratory conditions are statistically unconfident ( $p>005)$. We found that duration of work on treadmill is confidently connected with oxidation process of re-synthesis of adenosine triphosphate (ATP): with MOC r $=0.580$. It is known that in 400 meters' run and 400 meters hurdles high role is played by anaerobic glycolysis. Lactate concentration can change from 18 to $27-30 \mathrm{mmol}$ p.l. Therefore functional distinction and functional reserves can not be open to full extent in laboratory conditions (work on treadmill of 400 meters' runners and 400 meters' hurdles-runners).

That is why we made an attempt to compare assessment of sportsmen's competition functioning in specific and non-specific conditions. Wee studied functional condition of 7 the strongest 400 meters' hurdlesrunners. During one day the sportsmen fulfilled two competition loads: in the morning they ran 400 meters' distance as hurdles-runners; after 3 hours they ran 400 meters' smooth distance. The competitions were of selective character.

These competitions were conducted against the background of ordinary training process (there were no fasting days before competitions). That is why in blood we observed significant values of lactate ( $2.97 \pm 0.14$ and $3.13 \pm 0.24 \mathrm{mmol}$ p.l.). This fact points at finishing of recreational process.

Mean indicator of time of 400 meters' hurdles was $52.39 \pm 0.46$; of 400 meters of smooth run $49.83 \pm 0.38 \mathrm{sec}$. (differences are confident $\mathrm{p}<0.01$ ).

Analysis of HBR response to specific and non-specific loads did not show statistically confident differences $(\mathrm{p}>0.05)$ (see table 3$)$.

Table 3

Influence of specific and non-specific competition loads on functional and bio-chemical indicators of 400 meters' hurdles-runners

\begin{tabular}{|l|l|l|l|l|}
\hline \multirow{2}{*}{\multicolumn{1}{|c|}{ Indicators }} & \multicolumn{2}{c|}{400 meters' hurdles } & \multicolumn{2}{c|}{400 meters' run } \\
\cline { 2 - 5 } & \multicolumn{1}{|c|}{ In rest } & After load & In rest & After load \\
\hline HBR & $84.0 \pm 1.20$ & $197.0 \pm 9.1$ & $71.0 \pm 0.41$ & $184.0 \pm 3.1$ \\
\hline Lactate (mmol p.l.) & $2.77 \pm 0.31$ & $16.93 \pm 1.36$ & $3.13 \pm 0.49$ & $19.39 \pm 0.78$ \\
\hline Glucose (mmol p.l.) & $7.09 \pm 0.74$ & $5.77 \pm 0.33$ & $4.57 \pm 0.48$ & $6.37 \pm 0.71$ \\
\hline
\end{tabular}

Confident distinctions were observed when combining bio-chemical reactions to certain load. Different speed of run influenced differently on intensity of anaerobic glycolysis. Its indicator was level of lactate after work. As we can see this indicator is confidently higher with 400 meter" "smooth" run.

Increase of glucose in blood under less loads witnesses about mobilization of carbohydrate reserves of liver [4]. With fulfillment of two competition loads we observed glucose concentration in both cases. But its dynamic (rest-work-recreation) is ambiguous (see table 3).

Analysis of metabolic responses with fulfillment of two competition loads showed that sportsmen with high result on both distances did not differ significantly by functional responses. On the base of results of the research we can assume that the most promising for 400 meters' hurdles are sportsmen with high level of anaerobic glycolysis in "smooth" 400 meters' run.

\section{Discussion}

In process of training and competition functioning there appear changes of functional systems, which significantly increase special workability. Presence of objective information about levels of sportsmen's fitness permits to determine strong and weak sides of sportsmen's fitness. As a result it is possible to optimize training process $[3,4,9,10,11]$.

In kinds of sports with complex coordination against the background of speed-power endurance combination of anaerobic abilities with motor coordination is of great importance. Especially it is important in hurdles. Analysis of literature data witnesses that most of researches are devoted to different problems of sportsmen's training in "smooth" run. These researches dealt with development of hypoxic potentials $[6,11,13]$. 
The existing researches (A.L. Novikova, I.N. Soroka, 1994) recommend significant increasing of physical fitness [5]. S.V. Biriuk (2001) pays special attention to formation of run rhythm in hurdles on initial stage [1]. Chi Dunlin recommends to pay special attention to speed-power and coordination training [9, 10].

However, fundamental researches [2, 5, 15, 16, 17] show that in kinds of sports of sub maximal intensity study of oxygen demand and work's fulfillment energy cost as well as organism's adaptation potentials are of great importance.

However, with usage of dozed loads it is impossible to exactly restore advantages of sportsmen of different run specializations (L.G. Kharitonova, 1991; A.S. Rovniy, V.A. Rovniy 2009) [7, 8]. It is confirmed in our researches. We also affirm that for determination of functional potentials for certain kind of activity it is necessary to apply special loads.

Thus, the received results deepen information about specific features of mechanisms of adaptation to specific competition functioning. Correct approaches to processing and analysis of results of the research permit to more specifically determine sportsmen's functional potentials in different kinds of competition functioning.

\section{Conclusions}

Determination of promising sportsmen in laboratory conditions does not reflect actual special workability. Level of anaerobic glycolysis is a limiting factor of special workability of 400 meters' hurdlesrunners. The received results permit to say that application of the mentioned in this paper methods of research give objective information about special workability indicators and makes possible to prognosticate level of sport achievements.

\section{Conflict of interests}

The authors declare that there is no conflict of interests.

Reference

1. Biriuk SV. Formuvannia ritmu bigu z bar'ierami u khlopciv 13-15 rokiv na pochatku sportivnoi specializacii. Cand. Diss. [Formation of 13-15 years old boys' run rhythm in hurdles at the beginning of sport specialization. Cand. Diss.], Mikolaiv; 2001. (in Ukrainian)

2. Volkov NI, Biriuk SV, Savel'ev IA. Kislorodnyj zapros i energicheskaia stoimost' napriazhennoj myshechnoj deiatel'nosti [Oxygen demand and energy cost of tensed muscular functioning]. Fiziologiia cheloveka, 2002;28(4): 80-93. (in Russian)

3. Krivoshchekov SG, Divert GM, Divert VE. Rasshirenie funkcional'nogo diapazona reakcij dykhaniia i gazoobmena pri povtornykh gipoksicheskikh vozdejstviiakh [Expanding of functional range of gas metabolism and respiratory responses under repeated hypoxic impacts]. Fiziologiia cheloveka, 2005;31(3):100-107. (in Russian)

4. Mishchenko VS, Lysenko EN, Vinogradov VE. Reaktivnye svojstva kardiorespiratornoj sistemy kak otrazhenie adaptacii $k$ napriazhennoj fizicheskoj trenirovke $v$ sporte [Responsive characteristics of cardiorespiratory system as reflection of adaptation to intensive physical training in sports]. Kiev; 2007. (in Russian)

5. Novikov AL, Soroka IN. Trenirovka v bege na $400 \mathrm{~m} \mathrm{~s}$ bar'erami (muzhchiny) [Training in 400 meters hurdles (male)], Minsk; 1994. (in Russian)

6. Rovnaia OA, Il'in VN. Osobennosti adaptivnykh reakcij sistemy dykhaniia vysokvalificirovannykh sportsmenok sinkhronnogo plavaniia vo vremia interval'noj gipoksicheskoj trenirovki [Specific features of respiratory system's adaptation responses of elite synchronous swimmers during interval hypoxic training]. Pedagogics, psychology, medical-biological problems of physical training and sports, 2010;1:71-75. (in Ukrainian)

7. Rovnij AS, Rovnyj VA. Upravlenie sistemoj podgotovki iunykh begunov na $400 \mathrm{~m} \mathrm{~s}$ bar'erami [Management of junior 400 meters' hurdles-runners' training]. Slobozhans'kij naukovo-sportivnij visnik, 2009;1:72-75. (in Russian)

8. Kharitonova LG. Fiziologicheskie i biokhimicheskie aspekty adaptacii k intensivnym nagruzkam organizma begunov na $400 \mathrm{~m}$ s bar'erami [Physiological and bio-chemical aspects of adaptation to organism's intensive loads of 400 meters' hurdles-runners]. Teoriia i praktika fizicheskoj kul'tury, 1991;1:9-12. (in Russian) 
9. Shi Dulin. Skorostno-silovaia podgotovka iunykh begunov na $400 \mathrm{~m} \mathrm{~s}$ bar'erami [Speed-power training of junior 400 meters' hurdles-runners]. Slobozhans'kij naukovo-sportivnij visnik, 2004. 1: 40-43. (in Russian)

10. Shi Dulin. Razvitie koordinacionnykh sposobnostej kak osnova sovershenstvovaniia tekhniki bega na $400 \mathrm{~m}$ $\mathrm{s}$ bar'erami [raining of coordination as the basis of perfection of 400 meters' hurdles technique]. Slobozhans'kij naukovo-sportivnij visnik, 2005;1:125-129. (in Russian)

11. Bailey DM, Davies B, Baker J. Training in hypoxia: modulation of metabolic and cardiovascular risk factors in man. Med.Sci.Sports Exerc, 2000;32(6):1058-1063.

12. Bennet S. Training for $400 \mathrm{~m}$. Human Kinetics Pub; 1999.

13. Chick TW, Stark DM, Murata GH. Hyperoxic training increases work capacity after maximal training at moderate altitude. Chest; 1993;104:1759-1762.

14. Cheng Ping, Wang gig Yu. Technical training of $400 \mathrm{~m}$ Hurdle Race and the Rhythm among Hurdleg. Journal of Shandong Sports Science \& Technology. 2002;3:12-14.

15. Hochachka PW, Rupert JI, Monge C. Adaptation and conservation of physiological system in the evolution of human hypoxia tolerance. Comp. Biochem. Physiol; 1999;124:1-8.

16. Levine BD. Intermittent hypoxic training: fact and fancy. High Alt. Med. Biol., 2002;3(2):177-182.

17. Pearse WJ. Mechanisms of hypoxic cerebral vasodilatation. Pharmac. Tner., 1995;65:75-78.

18. Tian zhong Yan. A research on the contest Rhythm of World mans $400 \mathrm{~m}$ Hurdles. Journal of Shandong institute of Physical Education, 2003;2:103-105.

19. Yang Hui. Analysis on Chinese Excellent Athlete Luli Xiana Score of $110 \mathrm{~m}$ Men Hurdle. Journal of Beijing Sport University, 2003;11:1579-1581.

20. Zhao Jia Gni. On the Training of teen-agers 400-meters Hurdle Race. Journal of Anhui Polytechnic University Social Science, 2001;1:143-144.

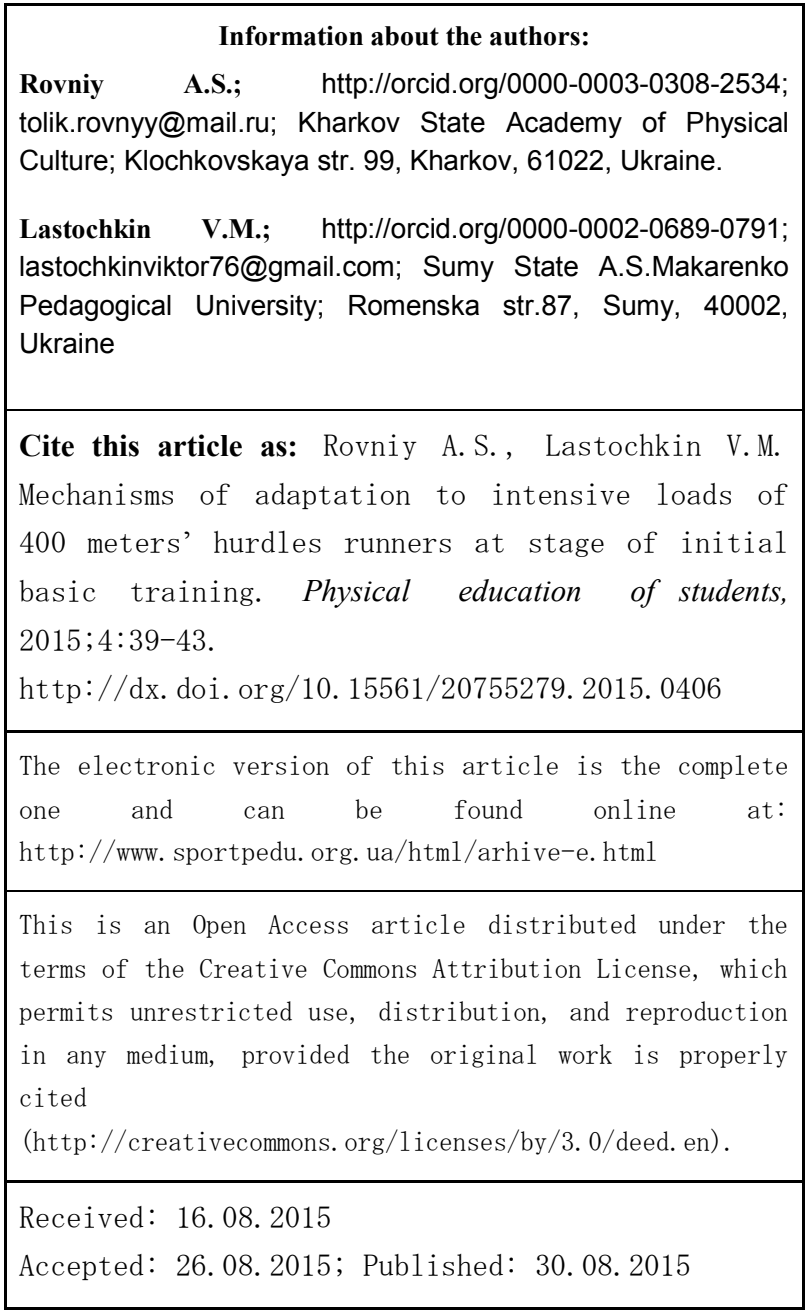




\title{
MODERN INFORMATION TOOLS: THEIR PLACE IN STUDENTS' EXTRA-CURRICULUM AND INVOLVEMENT OF THEM IN MOTOR ACTIVITY OF HEALTH RELATED ORIENTATION
}

Yurchyshyn Y.V.

Kamyanets-Podilsky Ivan Ohienko National University

\begin{abstract}
Purpose: to determine place and role of modern information tools in formation of motivation for health related motor functioning. Material: in the research 150 boys and 150 girls participated. All they were questioned. Results: we have determined that in hierarchy of students' functioning in extra-curriculum time its general kinds prevail. Special kinds of health related motor functioning take unfairly low position. Among general kinds of functioning Internet dominates. We found that health related motor functioning takes low position in general hierarchy: only $2 \%$ of girls and $5.3 \%$ of boys use it in form of training of favorite kind of sports; accordingly $8 \%$ and $6 \%$ - in the form of walks in the open air. Conclusions: it is necessary to uses students' preferences of Internet for their involvement in health related motor functioning.
\end{abstract}

Key words: students, extra-curriculum time, motivation, carrier of information, Internet, health related functioning.

\section{Introduction}

Health related motor functioning of students is realized in curriculum and extra-curriculum forms [8; 9]. Extracurriculum forms are realized in extra-curriculum time. It can be regarded as opportunity for student's free choice of kind of leisure [1; 4]; of entertainment; individual progressing; health related motor functioning; for solution of different tasks [1]. Extra-curriculum time is an important and determining element in aspect of health related motor functioning's systemic realization by students [3;12, 13-18].

In this connection information about students' functioning in extra-curriculum time is rather important and necessary: first of all for optimization of this functioning; for students' involvement in health related motor functioning $[2,5,11-12,19,20]$. Students' extra-curriculum functioning can be divided into general and special kinds. Special kinds can be characterized by health related orientation. Alongside with it some problems of organization of students motor functioning have still been remaining unsolved. In context of recent orders of Ministry of education and Decrees of Cabinet of Ministers students' extra-curriculum functioning has been becoming rather topical (http://mon.gov.ua/usinovivni/novini/2015/09/18/mizhvidomcha-robocha-grupa-fizvixovannya/).

Purpose, tasks of the work, material and methods

The purpose of the research is to determine place and role of modern information tools in formation of motivation for health related motor functioning.

The tasks of the research: determination of directions of students extra-curriculum functioning; determination of different information carriers' priority for students in mastering of academic disciplines; find out students' preferences concerning information carriers' usage for formation of health related knowledge; to study distribution of out-of-class time into different kinds of functioning by students.

The following methods of research were used: general (generalization of literature sources information), oral and written questioning, mathematical - statistic methods. The base of the research: Kamyanets-Podilsky Ivan Ohienko National University, Prikarpatskiy Vasil Stefanik national university and Ternopol Vladimir Gnatiuk national pedagogic university. In the research 150 boys and 150 girls participated. All students studied at different faculties, except faculty of physical education.

Results of he research

Questioning results showed that in extra curriculum time HEE girls try to achieve general aims: $44.7 \%$ - work in Internet; $21.3 \%$ - passive rest; $8 \%$ of boys and $8 \%$ of girls - communication with friends and watching TV; $7 \%$ computer games (see table 1). With it orientation of students' activity in Internet (from total 44.7\%) is as follows: $28.7 \%$ - communicative; $16 \%$ - entertaining; $1.3 \%$ - learning.

As for special kinds of functioning, they are represented by practicing of favorite kind of sports $-2 \%$; walks in the open air $-8 \%$ of students.

(c) Yurchyshyn Y.V., 2015

http://dx.doi.org/10.15561/20755279.2015.0307 
Table 1

Directions of students' functioning in extra-curriculum time

\begin{tabular}{|c|c|c|}
\hline \multirow{2}{*}{ Description of functioning } & \multicolumn{2}{|c|}{ Quantity of respondents, $\%$} \\
\hline & Girls $(n=150)$ & Boys $(n=150)$ \\
\hline \multicolumn{3}{|l|}{ General kinds } \\
\hline Watching TV & 8.0 & 6.7 \\
\hline Communication with friends & 8.0 & 10.0 \\
\hline $\begin{array}{l}\text { Work in Internet: } \\
\text { - cognitive }\end{array}$ & - & 0.7 \\
\hline - entertaining & 16.0 & 12.7 \\
\hline - learning & 1.3 & 1.3 \\
\hline - communicative & 28.7 & 26.0 \\
\hline Reading fictions, newspapers, magazines & - & - \\
\hline Computer games & 6.7 & 12.6 \\
\hline Passive rest & 21.3 & 18.7 \\
\hline \multicolumn{3}{|c|}{ Special kinds, connected with health related motor functioning } \\
\hline Practicing of favorite kind of sports & 2.0 & 5.3 \\
\hline Walks in the open air & 8.0 & 6.0 \\
\hline
\end{tabular}

Analyzing boys' data we registered analogous results but with certain specific features. In particular, boys prefer to spend free time in Internet with the following aims: communicative $-26 \%$; entertaining $-12.7 \%$; learning $-1.3 \%$; cognitive $-0.7 \%$ (see table 1). Passive rest dominates in structure of general kinds of activity in $18.7 \%$ of boys: communication with friends - 10\%; watching TV - 6.7\%. At the same time no one respondent (among boys and girls) preferred reading fiction, newspapers and magazines to other kinds of functioning. It witnesses about low status of such information carrier among.

In respect to health related motor functioning we found the following: only $6 \%$ of boys practice walks in the open air and 5.3\% - practice sports. Detail analysis of the mentioned above data from position of time for realization of different kinds of functioning showed the following: $58 \%$ of girls spend more than 3 hours for communication in Internet; $50.7 \%$ - for entertainment; $5.3 \%$ - for satisfaction of cognitive demands; $4.7 \%$ - for learning. Ежедневной работе в Интернет от 1 до 3 часов отводят 25,3\% девушек (соответственно 30\%, 12,7\% и 7,3\%); до 1 часа - 14\% (accordingly 11.3\%, 18.7\% and 9.3\%) (see table 2). At the same time for reading of books and periodic only 5.3\% of girls spend more than 3 hours every day; $8 \%-0$ from one to three hours and $12 \%$ - up to one hour. For preparation of home tasks they spend accordingly $12.7 \%, 20.7 \%$ and $65.3 \%$. 
Table 2

Distribution of extra-curriculum time by students in to different kinds of functioning

\begin{tabular}{|c|c|c|c|c|c|c|c|c|c|}
\hline \multirow[t]{2}{*}{ Description of functioning } & \multirow{2}{*}{ 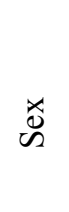 } & \multicolumn{2}{|c|}{ Up to 1 hour } & \multicolumn{2}{|c|}{ Up to3 hours } & \multicolumn{2}{|c|}{$\begin{array}{c}\text { More than } 3 \\
\text { hours }\end{array}$} & \multicolumn{2}{|c|}{ Do not spend time } \\
\hline & & A & $\%$ & A & $\%$ & A & $\%$ & A & $\%$ \\
\hline \multirow{2}{*}{ Watching TV } & $\mathrm{G}$ & 49 & 32.7 & 63 & 42.0 & 22 & 14.7 & 16 & 10.7 \\
\hline & $\mathrm{B}$ & 53 & 35.3 & 57 & 38.0 & 19 & 12.7 & 21 & 14.0 \\
\hline \multirow[t]{2}{*}{ Reading fictions, newspapers, } & $\mathrm{G}$ & 18 & 12.0 & 12 & 8.0 & 8 & 5.3 & 112 & 74.7 \\
\hline & $\mathrm{B}$ & 11 & 7.3 & 6 & 4.0 & 4 & 2.7 & 129 & 86.0 \\
\hline \multirow[t]{2}{*}{ Work in Internet for cognitive } & G & 14 & 9.3 & 11 & 7.3 & 8 & 5,3 & 117 & 78.0 \\
\hline & B & 17 & 11.3 & 7 & 4.7 & 4 & 2.7 & 122 & 81.3 \\
\hline \multirow{2}{*}{ Work in Internet for entertainment } & $\mathrm{G}$ & 17 & 11.3 & 45 & 30.0 & 76 & 50.7 & 12 & 8.0 \\
\hline & B & 24 & 16.0 & 39 & 26.0 & 72 & 48.0 & 15 & 10.0 \\
\hline \multirow[t]{2}{*}{ Work in Internet for communicative } & G & 21 & 14.0 & 38 & 25.3 & 87 & 58.0 & 4 & 2.7 \\
\hline & $\mathrm{B}$ & 25 & 16.7 & 34 & 22.7 & 82 & 54.7 & 9 & 6.0 \\
\hline \multirow[t]{2}{*}{ Work in Internet for learning } & $\mathrm{G}$ & 28 & 18.7 & 19 & 12.7 & 7 & 4.7 & 96 & 64.0 \\
\hline & B & 21 & 14.0 & 26 & 17.3 & 10 & 6.7 & 93 & 62.0 \\
\hline \multirow{2}{*}{ Walks in the open air } & $\mathrm{G}$ & 42 & 28.0 & 14 & 9.3 & 7 & 4.7 & 87 & 58.0 \\
\hline & B & 40 & 26.7 & 17 & 11.3 & 9 & 6.0 & 84 & 56.0 \\
\hline \multirow{2}{*}{$\begin{array}{c}\text { Verbal communication } \\
\text { (communication with friends and }\end{array}$} & $\mathrm{G}$ & 53 & 35.3 & 63 & 42.0 & 34 & 22.7 & - & - \\
\hline & B & 57 & 38.0 & 59 & 39.3 & 34 & 22.7 & - & - \\
\hline \multirow{2}{*}{ Computer games } & $\mathrm{G}$ & 48 & 32.0 & 29 & 19.3 & 11 & 7.3 & 62 & 41.3 \\
\hline & $\mathrm{B}$ & 55 & 36.7 & 22 & 14.7 & 35 & 23.3 & 38 & 25.3 \\
\hline \multirow{2}{*}{ Preparation of academic disciplines } & G & 98 & 65.3 & 31 & 20.7 & 19 & 12.7 & 2 & 1.3 \\
\hline & $\mathrm{B}$ & 92 & 61.3 & 34 & 22.7 & 12 & 8.0 & 12 & 8.0 \\
\hline Другой вариант & $\mathrm{G}$ & - & - & 7 & 4.7 & 4 & 2.7 & - & - \\
\hline (занятия спортом) & $\mathrm{B}$ & - & - & 11 & 7.3 & 6 & 4.0 & - & - \\
\hline
\end{tabular}

Notes: $\mathrm{G}$ - girls; B - boys; A - in absolute values. 
Analysis of girls' special functioning showed the following: walks in the open air take more than 3 hours $4.7 \%$ of girls; within 1-3 hours $-9.3 \%$; up to 1 hour $-28 \%$. Practicing of sports in first two variants was preferred accordingly by $2.7 \%$ and $4.7 \%$ of girls.

The boys were characterized as follows: everyday work in Internet for more than 3 hours with the following purposes: communication $-54.7 \%$; entertainment $-48 \%$; learning $-6.7 \%$; cognitive purposes $-2.7 \%$. From 1 to 3 hours they spend accordingly: $22.7 \%, 26 \%, 17.3 \%$ and $4.7 \%$; up to 1 hour $-16.7 \%, 16 \%, 14 \%$ and $11.3 \%$ of students. At the same time, reading books and periodic took more than 3 hours only $2.7 \%$ of boys; from 1 to 3 hours - $4 \%$; up to 1 hour $-7.3 \%$. Preparation of academic disciplines took accordingly соответственно $8 \%, 22.7 \%$ and $61.3 \%$.

Health related motor functioning in the form of walk in the open air took more than 3 hours of extra curriculum time only $6 \%$ of students; from 1 to 3 hours $-11.3 \%$, up to 1 hour $-26.7 \%$. Physical exercises (in first two variants) took accordingly $4 \%$ and $7.3 \%$ of students (see table 3 ).

In hierarchy of first year students' extra curriculum functioning, its general kinds prevail. Special kinds of health related motor functioning take unfairly low position. Among general kinds work in Internet (application of modern information tools) dominates.

Separately we studied the place of modern information tools in complex of information carriers. It was conditioned by demand in revelation of orientation of knowledge formation as well as skills and intensification of students' cognitive activity in educational process.

Table 3

Significance of different information carriers for students in their mastering academic disciplines

\begin{tabular}{|c|c|c|c|c|c|c|c|c|c|c|}
\hline \multirow{2}{*}{$\begin{array}{c}\text { Information carrier } \\
\text { (by questioning data) }\end{array}$} & \multicolumn{6}{|c|}{ Quantity of respondents with noted degree of information carriers' application, \% } \\
\cline { 2 - 14 } & \multicolumn{2}{|c|}{ Very often } & \multicolumn{2}{|c|}{ often } & \multicolumn{2}{|c|}{ Sometimes } & \multicolumn{2}{|c|}{ Seldom } & \multicolumn{2}{|c|}{ Never } \\
\cline { 2 - 13 } & $\mathrm{G}$ & $\mathrm{B}$ & $\mathrm{G}$ & $\mathrm{B}$ & $\mathrm{G}$ & $\mathrm{B}$ & $\mathrm{G}$ & $\mathrm{B}$ & $\mathrm{G}$ & $\mathrm{B}$ \\
\hline Manuals, recommendations & 25.3 & 22.7 & 37.3 & 34.7 & 20.0 & 26.7 & 17.3 & 16.0 & - & - \\
\hline Search systems of Internet & 70.0 & 65.3 & 21.3 & 24.7 & 8.7 & 10.0 & - & - & - & - \\
\hline Lecture notes & 34.7 & 31.3 & 56.0 & 48.0 & 9.3 & 20.7 & - & - & - & - \\
\hline Electronic manuals & 34.7 & 32.7 & 44.0 & 36.0 & 18.0 & 19.3 & 14.7 & 12.0 & - & - \\
\hline Internet learning sites & 9.3 & 8.0 & 26.0 & 27.3 & 34.7 & 34.0 & 22.7 & 21.3 & 7.3 & 9.3 \\
\hline Teacher's consultations & 8.7 & 7.3 & 9.3 & 11.3 & 26.0 & 25.3 & 39.3 & 34.0 & 16.7 & 22.0 \\
\hline
\end{tabular}

Notes: $\mathrm{G}$ - girls; B - boys.

When studying academic disciplines, in general $79.3 \%$ of girls and $73.3 \%$ of boys prefer information from Internet. Accordingly $23.3 \%$ and $32.7 \%$ - prefer electronic information carriers, available at HEE; $25.3 \%$ and $22.7 \%$ printed information carriers (manuals, recommendations); $34.7 \%$ and $31.3 \%$ - lecture notes; $8.7 \%$ and $7.3 \%$ - teachers' consultations (see table 3). Learning material on health related motor functioning most of students (girls $-60 \%$ and boys - 65.3\%) want to receive with electronic means. Accordingly $19.3 \%$ and $14 \%$ - prefer printed information carriers; $12.7 \%$ and $11.3 \%$ - at seminars; $8 \%$ and $9.3 \%$ - at lectures (see table 4 ). 
Students' preferences in usage of information carriers for formation of health related motor functioning knowledge

\begin{tabular}{|c|c|c|c|}
\hline \multirow{2}{*}{ Information carrier } & \multirow{2}{*}{ Sex } & \multicolumn{2}{|c|}{ Quantity } \\
\hline & & In absolute values & $\%$ \\
\hline \multirow{2}{*}{ Printed } & G & 29 & 19.3 \\
\hline & B & 21 & 14.0 \\
\hline \multirow{2}{*}{ Electronic } & G & 90 & 60.0 \\
\hline & B & 98 & 65.3 \\
\hline \multirow{2}{*}{ Lectures } & G & 12 & 8.0 \\
\hline & B & 14 & 9.3 \\
\hline \multirow{2}{*}{ Seminars } & G & 19 & 12.7 \\
\hline & B & 17 & 11.3 \\
\hline
\end{tabular}

The received data witness that in information carriers' hierarchy of first year students modern information tools dominate over traditional. It is conditioned by simplicity of search, processing and storage of different academic information, as well as by opportunity to improve the quality of independent learning functioning, create favorable conditions for communication, conditions for progressing of creative abilities, intensification and individualization of learning process. As a result cognitive functioning activates and increase of students' motivation for it rises.

\section{Discussion}

Thus, modern information tools are one of the main carriers of academic material, effective mean of students' cognitive functioning activation. Their application in different purposes is of priority in extra-curriculum time as well. It permits to use them for attracting of students to health related motor functioning. For this purpose it is recommended to conduct purposeful training of motivation for realization of such functioning in different forms, in extra-curriculum time.

Thus, physical education is of great importance in students' systemic realization of health related motor functioning. It is assumed to perfect this process in several directions. The found earlier [11-13] extremely low motivation of most of first year students for motor functioning is conditioned by insufficient formation of its procedural and efficient components. In our case they are determining for practicing of health related functioning [3, 6; 10]. These components of motivation are formed in process of physical and intellectual activity [7]. So, perfection of physical education process shall have complex character and include practical and theoretical components.

\section{Conclusions:}

Actual motivation of most of first year students for health related motor functioning in extra-curriculum time is extremely low. Its manifestation takes place only at compulsory physical culture classes. In context of recent requirements of Ministry of education (September 2015) physical education departments shall re-orient their work to extra-curriculum functioning. Most of first year students use Internet in extra-curriculum time. We have found out that in general values' hierarchy health related motor functioning takes low position: only $2 \%$ of girls and $5.3 \%$ of boys practice favorite kinds of sports. Accordingly, 8 and $6 \%$ - prefer walks in the open air. At the same time Internet is the leading tool for them in formation of knowledge, activation of cognitive processes. All these witness about demand in application of Internet for students' involving in health related motor functioning.

\section{Acknowledgement}

The work has been fulfilled in compliance with combined plan of scientific-research works in sphere of physical culture and sports for 2011-2015 by topic 3.9 "Perfection of scientific basis of ports for all, fitness and recreation" (0111U001735). 
It is purposeful to direct further researches for perfection of approaches, methods of usage of modern information tools for formation of students' individual motor functioning programs, knowledge on reasonable distribution of free time, increase of students' motivation for health related motor functioning.

\section{Conflict of interests}

The author declares that there is no conflict of interests.

\section{References:}

1. Bocheliuk VJ, Bocheliuk VV. Dozvillieznavstvo [Study of Leisure]. Kiev: Centre of Educational Literature; 2006. (in Ukrainian)

2. Volkov VL. Osnovi teorii ta metodiki fizichnoi pidgotovki students'koi molodi [Principles of theory and methodic of students' physical training], Kiev: Education Ukraine; 2008. (in Ukrainian)

3. Dekers L. Motivaciia [Motivation]. Moscow: Gross Media; 2007. (in Russian)

4. Dutchak MV. Sport dlia vsikh v Ukraini [Sports for all in Ukraine], Kiev: Olympic Literature; 2009. (in Ukrainian)

5. Iedinak GA. Stan ta deiaki teoretichni aspekti posilennia motivacii studentiv do sistematichnoi rukhovoi aktivnosti ozdorovchogo spriamuvannia [Status and some theoretical aspects of increase of students' motivation for systemic health related motor functioning]. Visnik Prikarpats'kogo nacional'nogo universitetu, 2012;16:67-73. (in Ukrainian)

6. Yermakova TS. Problema formuvannia zdorovogo sposobu zhittia starshoklasnikiv u vitchiznianij pedagogici (druga polovina XX stolittia). Cand. Diss. [Problem of formation of senior pupils' healthy life style in domestic pedagogic (second half of 20th century). Cand. Diss.], Kharkiv; 2010. (in Ukrainian)

7. Zaniuk SS. Psikhologiia motivacii [Psychology of motivation], Kiev: Lybed; 2002. (in Ukrainian)

8. Krucevich TIu. Teoriia $i$ metodika fizichnogo vikhovannia [Theory and methodic of physical education]. Kiev: Olympic Literature, 2008;T1. (in Ukrainian)

9. Krucevich TIu. Teoriia i metodika fizichnogo vikhovannia [Theory and methodic of physical education]. Kiev: Olympic Literature, 2008;T2. (in Ukrainian)

10. Khekgauzen Kh. Motivaciia i deiatel'nost' [Motivation and activity]. Sankt Petersburg: Peter; 2003. (in Russian)

11. Yurchyshyn YV. Tekhnologiia zaluchennia studentiv do rukhovoi aktivnosti ozdorovchoi spriamovanosti u procesi fizichnogo vikhovannia. Cand. Diss. [Technology of students' involving in health related motor functioning in process of physical education. Cand. Diss.], Kiev; 2012. (in Ukrainian)

12. Yurchyshyn YV, Dutchak MV. Efektivnist' eksperimental'noi tekhnologii zaluchennia studentiv do rukhovoi aktivnosti ozdorovchoi spriamovanosti u pokrashchenni pokaznikiv fizichnogo stanu [Effectiveness of experimental technology of students' involving in health related motor functioning, expressed in indicators of physical condition's improvement]. Pedagogics, psychology, medical-biological problems of physical training and sports, 2012;8:130-133. (in Ukrainian)

13. Dudnyk IO. Formation of positive motivation as the basis of students will qualities' perfection in physical culture practicing. Physical Education of Students, 2015;3:3-9. http://dx.doi.org/10.15561/20755279.2015.0301

14. Iermakova TS. Development of the idea of forming health culture of a person in the world educational thought. Pedagogics, psychology, medical-biological problems of physical training and sports, 2014;4:8-12. http://dx.doi.org/10.6084/m9.figshare.950949

15. Iermakova TS. Forming of healthylife style of pupils via prism of physical culture outside of school (historical aspect)ю Pedagogics, psychology, medical-biological problems of physical training and sports, 2011;6:50-56.

16. Ivashchenko OV, Yermakova TS. Assessment of functional, coordination and power fitness of 7-8 form boys. Pedagogics, psychology, medical-biological problems of physical training and sports. 2015;9:20-25. http://dx.doi.org/10.15561/18189172.2015.0903

17. Kozina ZL, Iermakov SS. Analysis of students' nervous system's typological properties, in aspect of response to extreme situation, with the help of multi-dimensional analysis. Physical Education of Students, 2015;3:10-19. http://dx.doi.org/10.15561/20755279.2015.0302

18. Yermakova TS. Individualization of forming health culture in schoolchildren of Polish schools. Pedagogics, psychology, medical-biological problems of physical training and sports. 2015;1:29-33. http://dx.doi.org/10.15561/18189172.2015.0106 
19. Yurchyshyn YV. Students' motivation building technology to motor activity of health improving direction during physical training. Journal of Health Sciences. 2014;2:109-116.

20. Źukowska Hanna, Szark-Eckardt Mirosława, Muszkieta Radosław, Iermakova TS. Characteristics of body posture in the sagittal plane and fitness of first-form pupils from rural areas. Pedagogics, psychology, medical-biological problems of physical training and sports, 2014;7:50-60. http://dx.doi.org/10.6084/m9.figshare.1015583

\begin{tabular}{|c|}
\hline Information about the author: \\
\hline $\begin{array}{l}\text { Yurchushun Y.V.; http://orcid.org/0000-0002-0341-3009; } \\
\text { yuriyyurchyshyn@gmail.com; Kamyanets-Podilsky Ivan } \\
\text { Ohienko National University ; Ivan Ohienko str., 61, } \\
\text { Kamenetz-Podolsky, Khmelnitsky region, 32300, Ukraine. }\end{array}$ \\
\hline $\begin{array}{l}\text { Cite this article as: Yurchyshyn Y.V. Modern } \\
\text { information tools: their place in students' } \\
\text { extra-curriculum and involvement of them in motor } \\
\text { activity of health related orientation. Physical } \\
\text { education of students, } \\
\text { http://dx. doi. org/10.15561/20755279.2015.0407 }\end{array}$ \\
\hline $\begin{array}{l}\text { The electronic version of this article is the complete } \\
\text { one and can be found online at: } \\
\text { http://www. sportpedu. org. ua/html/arhive-e. html }\end{array}$ \\
\hline $\begin{array}{l}\text { This is an Open Access article distributed under the } \\
\text { terms of the Creative Commons Attribution License, which } \\
\text { permits unrestricted use, distribution, and reproduction } \\
\text { in any medium, provided the original work is properly } \\
\text { cited } \\
\text { (http://creativecommons. org/1icenses/by/3.0/deed. en). }\end{array}$ \\
\hline Received: 06.08. 2015 \\
\hline Accepted: 26.08.2015; Published: 30.08. 2015 \\
\hline
\end{tabular}




\title{
SOMATIC ASPECTS OF SPORTS CHAMPIONSHIP IN TAEKWON-DO ITF \\ Jagiello W, ${ }^{1}$ Kozina Zh.L. ${ }^{2}$, Jagiello Marina ${ }^{1}$ \\ ${ }^{1}$ University of Physical Education and Sport, Gdansk, Poland \\ ${ }^{2}$ Kharkov National Pedagogical University, Ukraine
}

\begin{abstract}
The purpose of the study is to answer a basic question: which somatic characteristics of taekwon-do ITF athletes correlate the most with their sports level and experience training. Material: Representatives of the Polish taekwon-do ITF national team $(\mathrm{n}=21)$ took part in the study. The subjects' age was in the range of $18.51-$ 32.22 years $(24.5 \pm 4.1)$, and their training experience 8.4-22.4 years $(13.6 \pm 3,4)$. Results: Measurements of 20 basic somatic characteristics were taken. It was determined that correlations with the sports level and training experience were non-homogeneous and diverse due to the represented weight category. Conclusions: correlations of somatic indices with sports level and training experience among Polish representatives in taekwon-do are heterogeneous and largely dependent on weight category.
\end{abstract}

Keywords: taekwon-do, ITF, body, composition, sports, championship.

\section{Introduction}

Modern sport theorists and practitioners' research clearly indicates correlations between athletes' somatic composition and the represented by them sports discipline $[7,8,11,16]$.

In most cyclical disciplines of sport and team sports games, morphological indicators constitute the basic criterion for recruitment and selection. In many cases, they define the efficiency of the competitive activity and, what is directly connected with this, the level of sports championship $[1,6,10,17]$.

However, the problem is much more complex in speed-strength sports with a complicated coordination structure and a large range of body weight. Taekwon-do ITF undoubtedly meets these conditions [3, 18, 20].

Therefore, the purpose of the research is to answer a basic question: which somatic characteristics of taekwon-do ITF athletes correlate with the sports level and training experience to the greatest extent.

\section{Material and methods}

The study involved taekwon-do ITF athletes $(n=21)$. Among them 14 were representatives of Poland in senior category. The remaining subjects represented a high sports level. The subjects' age ranged between 18.51 and 32.22 years $(24.5 \pm 4.1)$, body weight varied within $62.70-100 \mathrm{~kg}(75.3 \pm 10.3)$, and the body height $167.0-$ $195 \mathrm{~cm}$ (179.6 \pm 8.3 ). The sports level was determined on the basis of experts' opinions (coaches of the Polish national team in Taekwon-do ITF) by means of ranking.

The training experience varied between 8.4 and 22.4 years (13.6 \pm 3.4$)$ and was significantly varied $(\mathrm{V} \%=24.8)$. Anthropometric measurements were taken during the Polish national team camp trainings (Spala Central Sport Centre, February 29-March 5, 2012) and during Seniors and Juniors Polish Cup competitions (Klobuck, 2-4 February 2012).

Anthropometric measurements were taken in accordance with the adopted rules [4], using standard instruments. In addition, five indicators were calculated: slenderness, Rohrer's, Quetelet's II. Manouvrier's, and the shoulder-pelvis index.

The total body fat in percentage from body weight was calculated according to Brożek and Keks's equation [2]. The density of body, on the basis of measurements of subcutaneous fat, was calculated by Piechaczek's anticipating equation [19]. Measurements of total of 20 basic somatic characteristics were made.

The results of the study were then subjected to basic statistical analysis by calculating the arithmetic mean $(\mathrm{X})$, the standard deviation $( \pm \mathrm{SD})$, the coefficient of variation $(\mathrm{V} \%)$ and the level of correlations $(\mathrm{r})$.

Results

Correlations of somatic characteristics with training experience (TE) and sports level (SL) among taekwon-do athletes show a varied character (Tab. 1).

Taking into account mean value of all the correlations, they are slightly higher in relation to the training experience than to the sports level (0.439 and 0.370, respectively), and they represent an average level. However, if to consider weight categories. mean value of correlations between somatic characteristics and the sports level is the greatest in the hyper-weight category $(\mathrm{r}=0.462)$ and the light-weight one $(\mathrm{r}=0.440)$, and the weakest one in the middle-weight category $(\mathrm{r}=0.232)$. Level of correlations with the training experience is slightly higher. In hyper-weight category it amounts to 0.506 , in light-weight one 0.506 , and it is the lowest in the middle-weight category $(\mathrm{r}=0.372)$.

\footnotetext{
() Jagiello Wladyslaw, Kozina Zh.L., Jagiello Marina, 2015 http://dx.doi.org/10.15561/20755279.2015.0408
} 
Table 1

Correlations of somatic characteristics with the training experience (TE) and the sports level (SL) among taekwon-do athletes, different weight categories

\begin{tabular}{|c|c|c|c|c|c|c|c|c|}
\hline \multirow{3}{*}{ Somatic characteristics } & \multicolumn{8}{|c|}{ Weight categories } \\
\hline & \multicolumn{2}{|c|}{$<63 \mathrm{~kg}, \mathrm{n}=5$} & \multicolumn{2}{|c|}{$<71 \mathrm{~kg}, \mathrm{n}=6$} & \multicolumn{2}{|c|}{$<80 \mathrm{~kg}, \mathrm{n}=6$} & \multicolumn{2}{|c|}{$>80 \mathrm{~kg}, \mathrm{n}=4$} \\
\hline & TE & SL & TE & SL & TE & SL & TE & SL \\
\hline body mass & 0.137 & -0.635 & -0.357 & 0.131 & -0.305 & -0.217 & 0.771 & -0.636 \\
\hline body height & -0.560 & 0.354 & -0.307 & -0.138 & 0.256 & -0.375 & 0.607 & -0.735 \\
\hline sitting body height & 0.100 & 0.694 & -0.322 & -0.174 & -0.352 & -0.131 & 0.608 & -0.513 \\
\hline length of upper extremity & -0.424 & -0.150 & -0.281 & -0.390 & -0.220 & -0.221 & -0.097 & -0.689 \\
\hline length of lower extremity & -0.730 & 0.131 & -0.715 & -0.561 & 0.721 & -0.627 & -0.332 & 0.148 \\
\hline pelvic width & 0.415 & 0.920 & -0.236 & 0.298 & 0.298 & 0.202 & 0.875 & -0.322 \\
\hline shoulders width & -0.607 & -0.009 & -0.493 & -0.058 & -0.388 & 0.255 & 0.759 & 0.053 \\
\hline elbow width & -0.161 & 0.446 & -0.173 & 0.325 & -0.100 & 0.217 & -0.143 & 0.775 \\
\hline knee width & 0.741 & 0.394 & 0.440 & 0.202 & -0.077 & 0.749 & 0.409 & 0.408 \\
\hline forearm perimeter & -0.564 & -0.433 & 0.474 & -0.217 & 0.731 & -0.727 & 0.466 & -0.078 \\
\hline shank perimeter & 0.381 & 0.683 & -0.333 & -0.652 & 0.420 & -0.802 & 0.199 & 0.366 \\
\hline body density & -0.217 & 0.488 & 0.377 & -0.060 & 0.770 & -0.216 & -0.664 & 0.610 \\
\hline fat $\%$ & 0.217 & -0.489 & -0.374 & 0.063 & -0.770 & 0.215 & 0.665 & -0.610 \\
\hline active tissue \% & -0.217 & 0.489 & 0.374 & -0.063 & 0.770 & -0.215 & -0.665 & 0.610 \\
\hline body surface & -0.588 & 0.310 & -0.313 & -0.134 & 0.210 & -0.374 & 0.835 & -0.727 \\
\hline slenderness index & -0.551 & 0.366 & -0.304 & -0.139 & 0.272 & -0.375 & -0.433 & 0.243 \\
\hline Rohrer's index & 0.531 & -0.376 & 0.283 & 0.147 & -0.268 & 0.382 & 0.411 & -0.233 \\
\hline BMI index & 0.531 & -0.379 & 0.286 & 0.146 & -0.277 & 0.380 & 0.545 & -0.375 \\
\hline Manouvrier's index & -0.685 & -0.430 & 0.294 & 0.199 & 0.624 & -0.213 &.,- 318 & -0.293 \\
\hline Shoulder-pelvis index & 0.732 & 0.630 & 0.707 & 0.553 & 0.640 & -0.034 & 0.318 & -0.812 \\
\hline
\end{tabular}

High level of correlations between somatic characteristics with the sports level in the light-weight category was recorded with reference to the pelvis width $(\mathrm{r}=0.92)$. In middle-weight category no correlations at high level were noted. In heavy-weight category high correlations of the sports level became apparent with the shank perimeter $(\mathrm{r}=-0.80)$, knee width $(\mathrm{r}=0.75)$, and forearm perimeter $(\mathrm{r}=-0.73)$. In hyper-weight category 4 correlations were revealed at a high level: with the shoulder-pelvis index $(\mathrm{r}=-0.81)$, elbow width $(\mathrm{r}=0.78)$, body height $(r=-0.74)$ and body surface $(r=-0.74)$. The structure of correlations between somatic characteristics and sports level is varied depending on the weight category (Figure 1). 


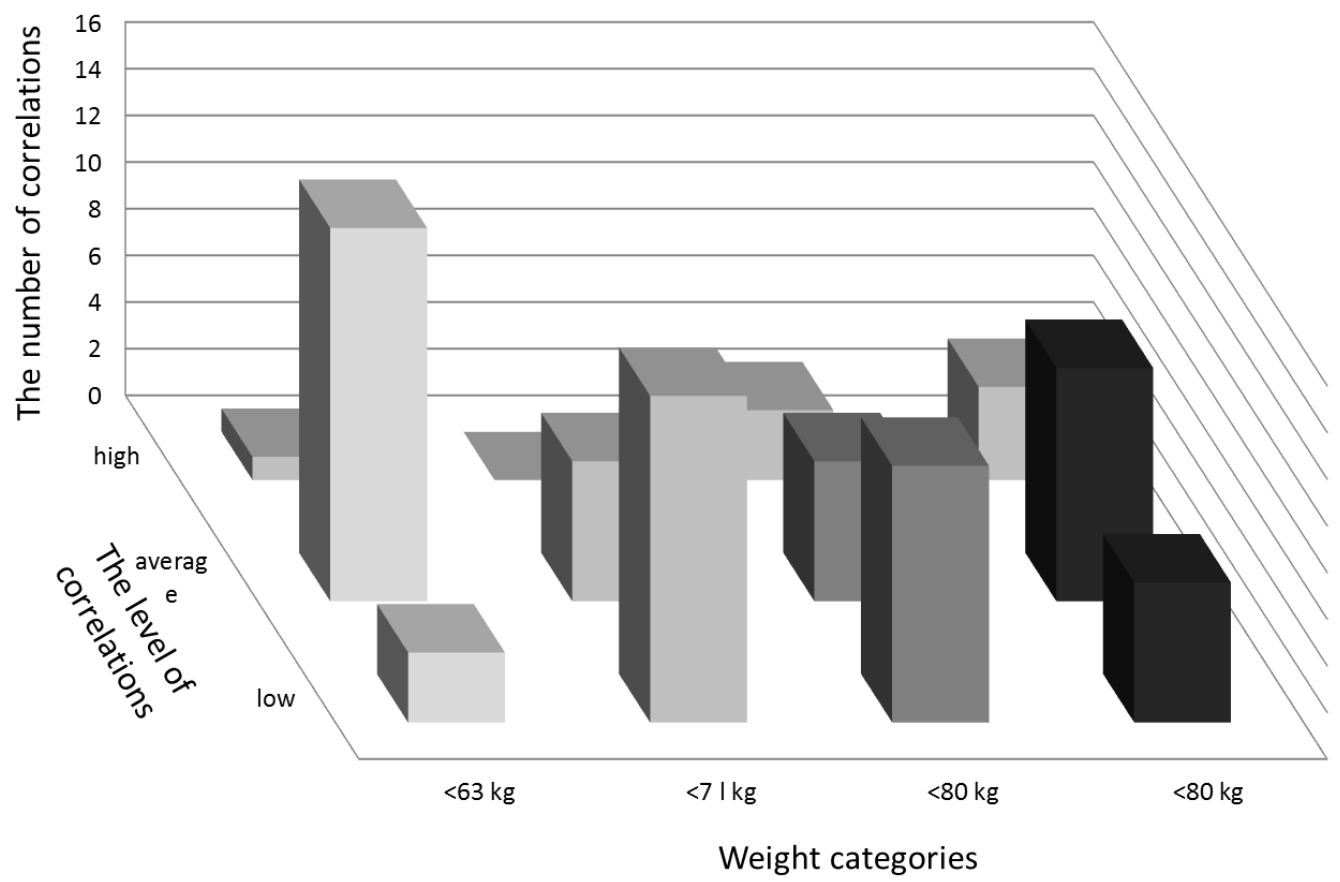

Fig. 1. The structure of correlations between somatic characteristics and the sports level among highly qualified taekwon-do ITF athletes.

The high level of correlations between somatic characteristics and the training experience in the lightweight category was revealed in relation to the knee width $(\mathrm{r}=0.74)$ and the length of the lower extremity and the shoulder-pelvis index $(\mathrm{r}=0.73)$. In the middle-weight category, high correlations were reported with reference to the length of the lower extremity $(\mathrm{r}=-0.72)$ and the shoulder-pelvis index $(\mathrm{r}=0.71)$. In the heavyweight category 5 correlations were revealed at a high level: with the body density, and the directly related fat content and the active body weight $(-0.77$; and 0.77 , respectively), with the forearm perimeter $(0.73)$ and the length of the lower extremity (0.72). In hyper-weight category 4 correlations were recorded at a high level: with the pelvic width index $(\mathrm{r}=0.88)$, the body surface $(\mathrm{r}=0.84)$, the body mass $(\mathrm{r}=0.77)$ and the shoulders width $(\mathrm{r}=0.76)$.

The structure of correlations between somatic characteristics and the training experience is again varied, depending on weight categories (Figure 2).

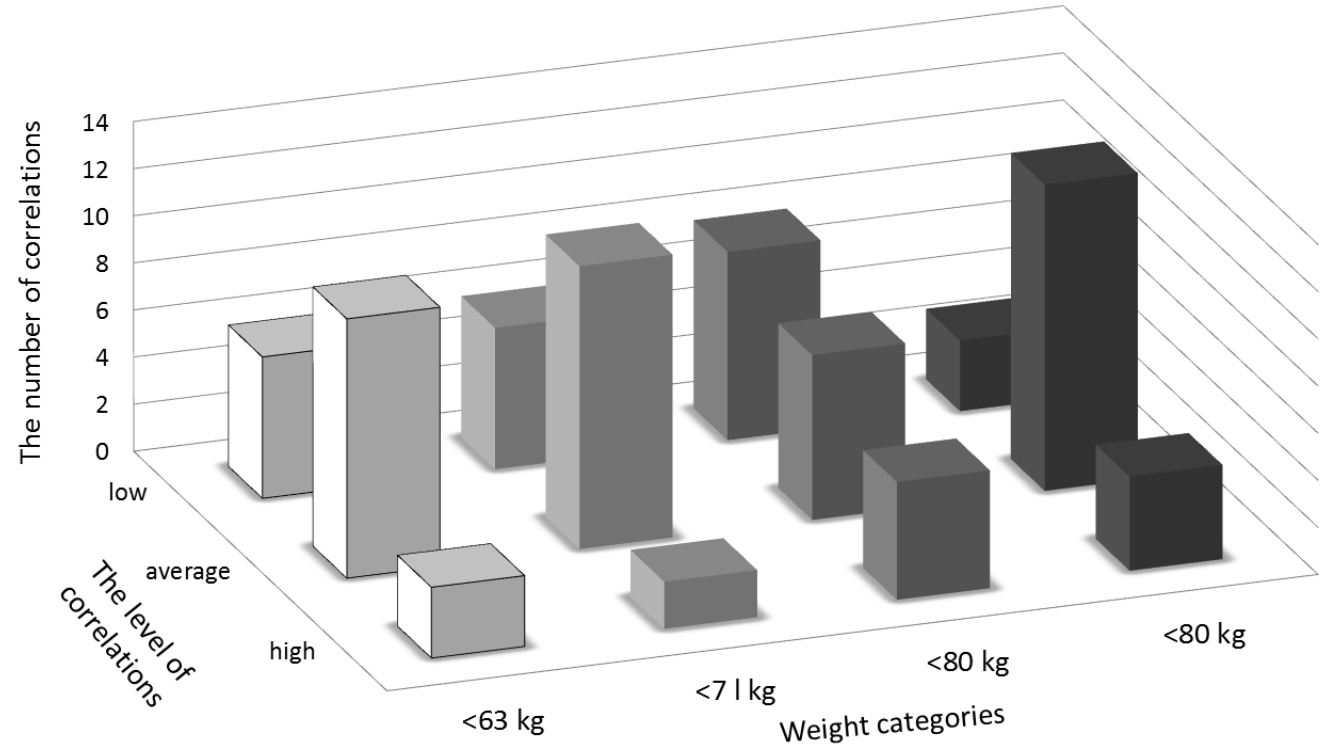

Fig. 2. The structure of correlations between somatic characteristics and the training experience among highly qualified taekwon-do ITF athletes. 


\section{Discussion}

The study results clearly indicate that the problem of constitutional aspects of taekwon-do ITF athletes' sports championship is a complex scientific issue. In research on Polish male and female representatives in wrestling $[12,13]$, the authors state that with an increase in body mass also the number and the level of correlations between somatic characteristics and the sports level and training experience increases. Just as in this study, a slightly higher level of correlations is observed with training experience than with the sports level.

A study of Polish representatives in modern pentathlon [9] showed that among women anthropometric indices correlate with the training experience to a greater extent than with sports level. On the other hand, males' sports level is more closely associated with their somatic composition.

An interesting study was conducted with a group of women practicing fencing [5]. A high correlation between body composition and the sports experience was reported only in relation to one somatic index Manouvrier's index. As to sports level, correlations at high level were revealed with three somatic characteristics: body weight, forearm perimeter and upper extremity length.

The study, which was conducted at the European Championships in tennis [14] revealed an important trend. Along with increase in tennis players' sports level, a reduction in the athletes' body massiveness indices was reported. Hence, the authors conclude that tennis players' slim body build can predispose them to achieving better sports results. Also study of Polish tennis representatives [6] showed that somatic indices have larger impact on men's sports level than on women's. A correlation between tennis players' body composition and their training experience is high with reference to two indices: elbow width and forearm perimeter. Only knee width highly correlates with their sports level. Among men only pelvis width correlates with training experience at high level. In turn, as many as six indices correlate with sports level: body height, upper extremity length, forearm and shank perimeter, body weight and its surface. The authors conclude that the structure of the correlations between somatic indices and sports level and training experience in tennis has a dimorphic character.

Taking into account overall index of correlation of somatic characteristics among Polish representatives in taekwon-do ITF with their training experience and sport level, as in most of analysed researches, a higher correlation was noted with the training experience than with sports level. In all analysed weight categories, mean value of correlations of somatic characteristics with sports level was lower than in relation to training experience.

Shank perimeter highly correlates with sports level in all weight categories (apart from the hyper-weight one) -mean value of correlation index for all categories amounts to 0.63 , just as shoulder-pelvis index (apart from the heavyweight category) -0.51 .

High correlation with training experience was reported for lower extremity length (apart from the hyperweight category) - the mean value of the correlation index was 0.62, for the shoulder-pelvis index (apart from the hyper-weight category) - the mean value of the correlation index was 0.60; for the shoulder width (apart from the heavyweight category) and for the forearm perimeter - the mean value of the correlation index was 0.56 .

The results of the conducted studies and literature analysis give grounds to believe that the problem of somatic aspects of sports championship is a very complex and ambiguous issue. A sport discipline (the nature of effort) and the weight categories, in which a bout takes place has an impact on the structure and level of correlations.

\section{Conclusions}

1. Correlations of somatic indices with sports level and training experience among Polish representatives in taekwon-do are heterogeneous and largely dependent on weight category.

2. Shank perimeter (apart from the hyper-weight category) and shoulder-pelvic index (apart from the heavy weight category) highly correlate with sports level in all weight categories.

3. Lower extremity length (apart from hyper-weight category), shoulder-pelvis index (apart from hyperweight category), shoulder width (apart from heavy weight category) and forearm perimeter highly correlate with training experience.

\section{References}

1. Baxter-Jones ADG, Helms P, Maffulli N, Baines-Preece JC. Growth and development of male gymnasts, swimmers, soccer and tennis players: a longitudinal stady. Annals of Human Biology, 1995;5:381-394.

2. Brożek J, Keys A. The evaluation of leanness fatness in man. Norm and interrelationships. Brit. J. Nutr. 1949;5:194-206.

3. Bujak Z. Physical development and physical fitness of people practice taekwon-do. Warsaw; 2000.

4. Drozdowski Z. Anthropometry in physical education. Textbooks, 1998;24:54-60.

5. Jagiełło M, Jagiełło W. Somatic Aspects of Sports Mastery in Female Competitors of the Polish National Fencing Team. Pedagogics, psychology, medical-biological problems of physical training and sports. 2008;7:160-162. 
6. Jagiełło M, Jagiełło W. Constitutional aspects of sports mastery in tennis. Physical education of students, 2009;1:73-76.

7. Jagiełło W. Differentiation of the body build in judo competitors of the men's Polish national team. Archives of Budo, 2013;9(2):117-123.

8. Jagiełło W, Jagiełło M. Internal proportions of body build of the Polish representatives in tennis. Pedagogics, psychology, medical-biological problems of physical training and sports. 2006;5:141-145.

9. Jagiełło W, Jagiełło M. Constitutional aspects of sports mastery in modern pentathlon Pedagogics, psychology, medical-biological problems of physical training and sports. 2009;11:154-157.

10. Jagiełł W, Jagiełło M, Kozina ZhL. Type of structure of men body engaged baseball. Physical education of students, 2012;6:140-143.

11. Jagiełło W., Kalina R., Korobielnikow G. Morphological diversification of female judo athletes. Archives of Budo, 2007, Vol. 3:27-34.

12. Jagiełł W, Kruszewski A. Somatic aspects of sports mastery of Polish representatives in wrestling. Pedagogics, psychology, medical-biological problems of physical training and sports. 2008;7:160-162.

13. Jagiełło W, Kruszewski A. Morphological Diversification of Competitors Training Greko-Roman Style of Wrestling. Archives of Budo, 2009;5:147-153.

14. Jagiełło M, Tkaczuk W, Jagiełł W. Somatic aspects of sports mastery female tennis players. Physical training of students of creative specialties. 2003;2:3-10.

15. Jagiełł W, Wołowicz J. Body Composition in Junior Polish Representatives in Judo. Pedagogics, psychology, medical-biological problems of physical training and sports. 2009;12:196-201.

16. Leake CN, Carter JE. Comparison of body composition and somatotype of trained female triathletes. Journal of Sports Sciences, 1991;9(2):125-135.

17. Litwiniuk S. Taekwon-do ITF as a form of physical activity and sport discipline. Biala Podlaska: IWFiS; 2000.

18. Piechaczek H. Determination of total fat densitometry and anthropometric methods. Materials and work Anthropological, 1975;89:3-48.

19. Saczuk J, Wilczewski A. Assessing body composition taekwondo athletes. Warsaw; 2002.

Information about the authors:

Jagiello Wladyslaw; http://orcid.org/0000-0001-7417-4749; wjagiello1@wp.pl; Gdansk University of Physical Education and Sport; ul. Wiejska 1, 80-336 Gdansk, Poland.

Kozina Zh.L.; http://orcid.org/0000-0001-5588-4825; Zhanneta.kozina@gmail.com; Kharkov National Pedagogical University; Artema str. 29, Kharkov, 61002, Ukraine.

Jagiello Marina; http://orcid.org/0000-0001-5591-4537; wjagiello1@wp.pl; Gdansk University of Physical Education and Sport; ul. Wiejska 1, 80-336 Gdansk, Poland.

Cite this article as: Jagiello Wladyslaw, Kozina Zh. L., Jagiello Marina. Somatic aspects of sports championship in taekwon-do ITF. Physical education of students, 2015;4:51-55. http://dx. doi. org/10. 15561/20755279. 2015. 0408

The electronic version of this article is the complete one and can be found online at: http://www. sportpedu. org. ua/html/arhive-e. html

This is an Open Access article distributed under the terms of the Creative Commons Attribution License, which permits unrestricted use, distribution, and reproduction in any medium, provided the original work is properly cited (http://creativecommons. org/1icenses/by/3.0/deed. en).

Received：18.08.2015

Accepted: 26.08.2015; Published: 30.08.2015 
SUBMISSION OF MANUSCRIPTS

(For more detailed information see http://www.sportpedu.org.ua/html/trebovaniya-e.html)

Structure of article:

- title of an article;

- surname, full first name and patronymic;

- full name of organization (place of work or study);

- annotation in three language (Russian, Ukrainian, English). The scope of the annotation is to be 800-1000

symbols. Annotation must contain translate of surname, full first name and patronymic of authors, in Ukrainian

(Russian) and English. Structure of annotation: aim, material, result. For authors from Russia, the translation in the Ukrainian language makes editorial board.

- Key words for the three languages: ( 1-2 lines of words. Do not use word combinations).

- Introduction (statement of a problem; analysis of the last researches and publications of this theme; to single out the open problem in the research article).

- Connection of the article with important scientific programs or practical tasks.

- Aim, tasks, material and methods.

- Results of the research (description of the main research material with full substantiation of the derived scientific results).

- Findings.

- Perspectives of future researches in this direction.

- Bibliographic references (more than 20) should be making up according to standard form.

REVIEW PROCEDURE FOR MANUSCRIPTS (For more detailed information see http://www.sportpedu.org.ua/html/ recenzirovaniye-e.html) All manuscripts submitted for publication must go through the review process.

TREATMENT OF MANUSCRIPTS (For more detailed information see http://www.sportpedu.org.ua/html/ rassmotreniye-e.html)

Manuscripts are assessed by the Editorial Board within 1 month.

The Journal will acknowledge receipt of a manuscript within 2 days.

EDITORIAL ETHICS (For more detailed information see http://www.sportpedu.org.ua/html/ethics-e.html) The journal is committed to a high standard of editorial ethics.

Editorial board is used the principles of ethics of scientific publications upon recommendations of International Committee of Medical Journal Editors.

Conflicts of interests of persons who have direct or indirect relation to the publication of an article or any information that the article consist are settled according to the law of Ukraine in the field of intellectual property.

\section{CONTACT INFORMATION}

box 11135, Kharkov-68, 61068, Ukraine

phone. +380994306922

http://www.sportpedu.org.ua

e-mail: sportart@gmail.com 


\section{Information Sponsors, Partners, Sponsorship:}

- Olympic Academy of Ukraine,

- Ukrainian Academy of Sciences.

\section{SCIENTIFIC EDITION (journal)}

Physical Education of Students 2015;4; 60.

Editorial to the publisher department KSPU: certificate DK №860 20.03.2002.

designer-lermakov $\mathrm{S}$

editing - Yermakova T.

administrator of sites - lermakov $S$.

designer cover - Bogoslavets A.

passed for printing 30.08.2015.

Format A4.

PRINTHOUSE (B02 № 248 750, 13.09.2007).

61002, Kharkov, Girshman, 16a. 